W O R L D B A N K W O R K I N G PAPER N O . A FR I C A HUMA N DEVELOPMEN T SERIES

Curricula, Examinations, and Assessment in Secondary

\title{
Education in Sub-Saharan Africa
}

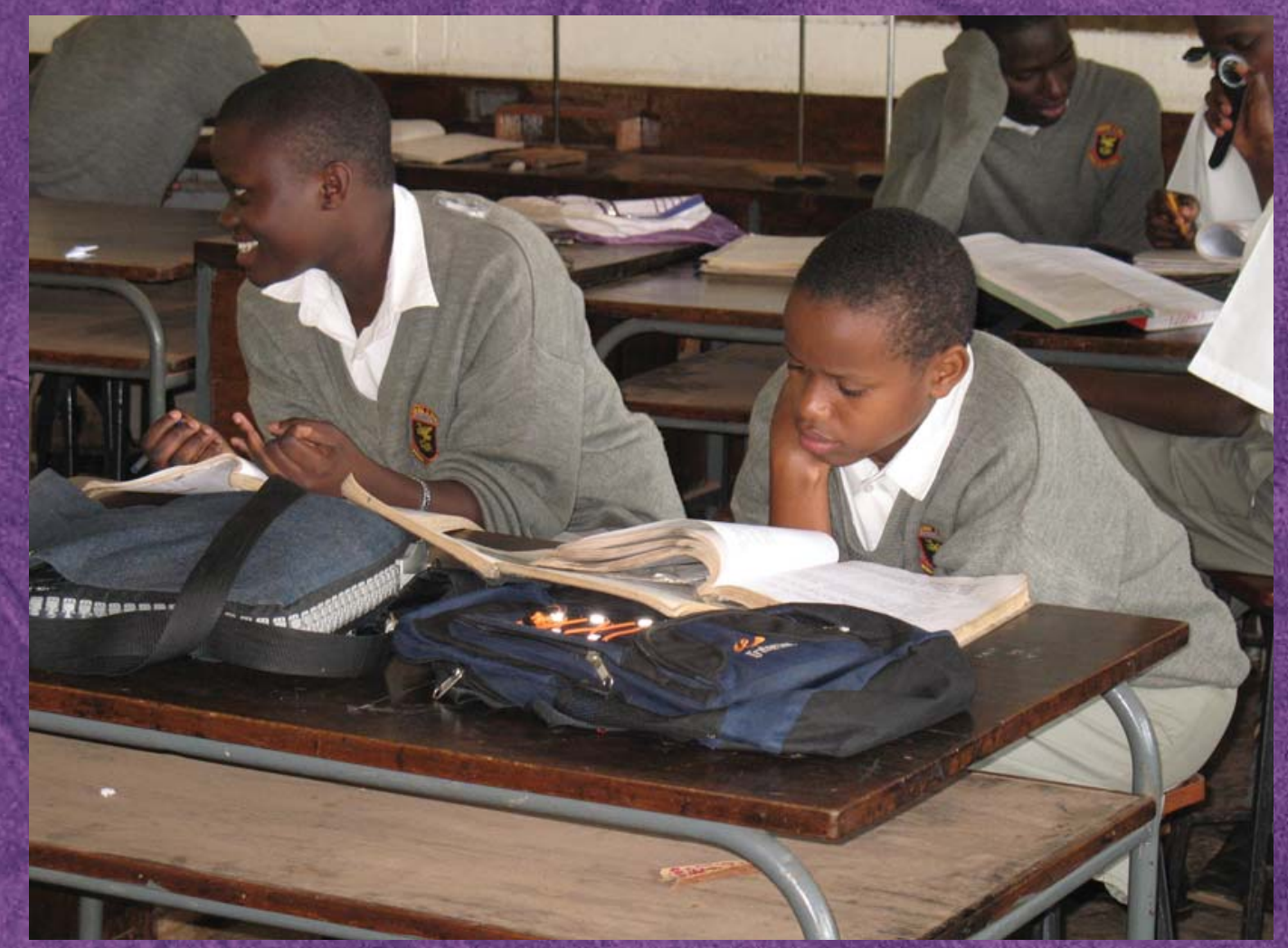

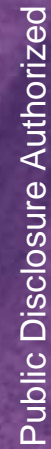

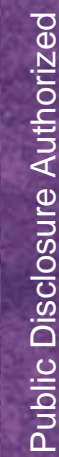

(4) THE WORLD BANK 
\begin{tabular}{llllllllllllllllllllllll} 
W O R L D & B A N N & W O R K I N G & P A P E R N N & O & 1 & 2 & 8 \\
\hline
\end{tabular}

\section{Curricula, Examinations, and Assessment in Secondary Education in Sub-Saharan Africa}

Secondary Education in Africa (SEIA)

Africa Region Human Development Department

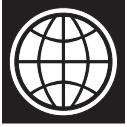

THE WORLD BANK

Washington, D.C. 
Copyright (C) 2008

The International Bank for Reconstruction and Development/The World Bank

1818 H Street, N.W.

Washington, D.C. 20433, U.S.A.

All rights reserved

Manufactured in the United States of America

First Printing: January 2008

8 printed on recycled paper

1234510090807

World Bank Working Papers are published to communicate the results of the Bank's work to the development community with the least possible delay. The manuscript of this paper therefore has not been prepared in accordance with the procedures appropriate to formally-edited texts. Some sources cited in this paper may be informal documents that are not readily available.

The findings, interpretations, and conclusions expressed herein are those of the author(s) and do not necessarily reflect the views of the International Bank for Reconstruction and Development/The World Bank and its affiliated organizations, or those of the Executive Directors of The World Bank or the governments they represent.

The World Bank does not guarantee the accuracy of the data included in this work. The boundaries, colors, denominations, and other information shown on any map in this work do not imply any judgment on the part of The World Bank of the legal status of any territory or the endorsement or acceptance of such boundaries.

The material in this publication is copyrighted. Copying and/or transmitting portions or all of this work without permission may be a violation of applicable law. The International Bank for Reconstruction and Development/The World Bank encourages dissemination of its work and will normally grant permission promptly to reproduce portions of the work.

For permission to photocopy or reprint any part of this work, please send a request with complete information to the Copyright Clearance Center, Inc., 222 Rosewood Drive, Danvers, MA 01923, USA, Tel: 978-750-8400, Fax: 978-750-4470, www.copyright.com.

All other queries on rights and licenses, including subsidiary rights, should be addressed to the Office of the Publisher, The World Bank, 1818 H Street NW, Washington, DC 20433, USA, Fax: 202-522-2422, email: pubrights@worldbank.org.

ISBN-13: 978-0-8213-7348-4

eISBN: 978-0-8213-7349-1

ISSN: $1726-5878$

DOI: $10.1596 / 978-0-8213-7348-4$

Cover photo by Jaap Bregman.

Library of Congress Cataloging-in-Publication Data has been Requested 


\section{Contents}

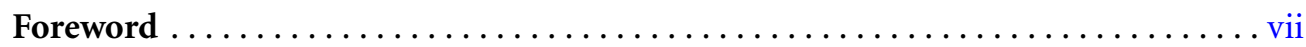

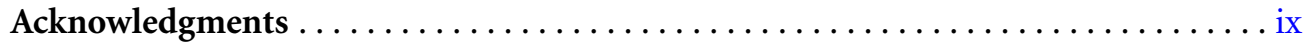

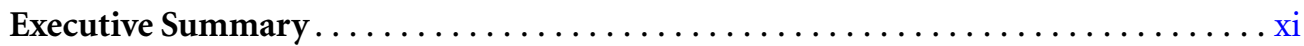

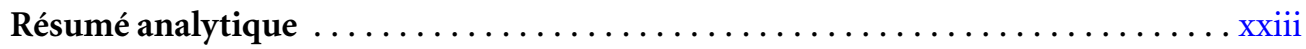

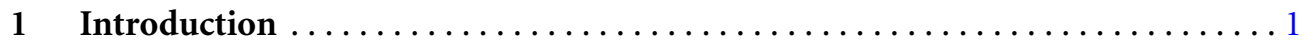

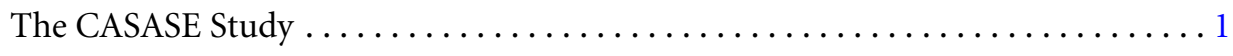

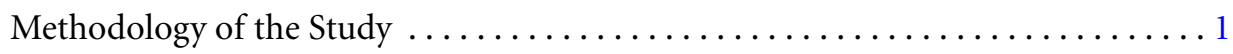

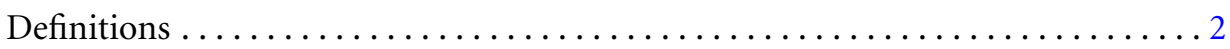

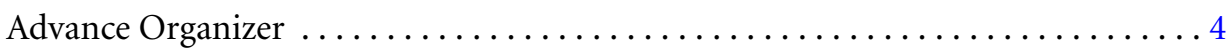

2 Context of the Sub-Saharan African Secondary Education $\ldots \ldots \ldots \ldots \ldots \ldots \ldots$

Enrollment in Secondary Education in Sub-Saharan Africa . . . . . . . . . . . 5

Primary Completion Rates, Transfer Rates, and Gross Enrollment Ratios ....... 5

Teachers and Student Teacher Ratios. . . . . . . . . . . . . . . . 7

Differences Across Sub-Saharan African Countries . . . . . . . . . . . . . . 7

Social Perceptions of Education and Vocational Education $\ldots \ldots \ldots \ldots \ldots . . .8$

3 Access, Equity, Quality, and Curriculum $\ldots \ldots \ldots \ldots \ldots \ldots \ldots \ldots \ldots \ldots \ldots$

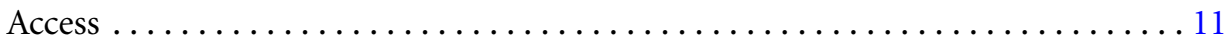

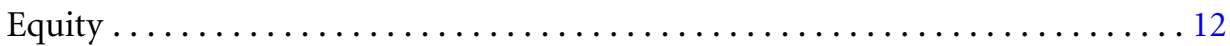

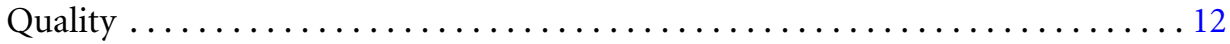

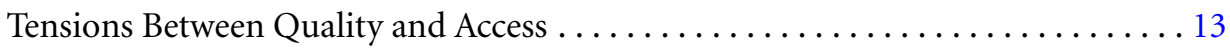

Quality and Curriculum Reform $\ldots \ldots \ldots \ldots \ldots \ldots \ldots \ldots \ldots \ldots \ldots \ldots \ldots \ldots \ldots \ldots \ldots \ldots$

4 Formal Curriculum and Curriculum Structures in Sub-Saharan Africa . . . . . 15

Lengths of Educational Cycles Across Sub-Saharan Africa . . . . . . . . . . . 15

Curriculum Structures in the Five Countries Visited . . . . . . . . . . . 15

Position of Technical and Vocational Education $\ldots \ldots \ldots \ldots \ldots \ldots \ldots \ldots \ldots \ldots \ldots \ldots \ldots$

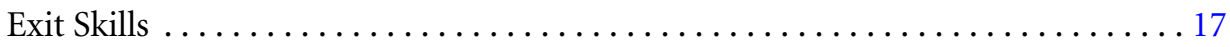

Issues in Secondary Education Curriculum $\ldots \ldots \ldots \ldots \ldots \ldots \ldots \ldots \ldots \ldots \ldots \ldots \ldots$

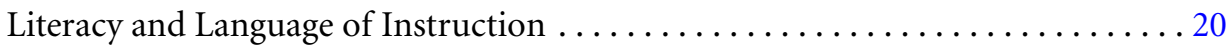

Junior Secondary Education as Part of Basic Education .............. 22 
Subjects and Learning Areas in Junior Secondary Education . . . . . . . . . 22

Curriculum Extensions at Both Junior and Secondary Level . . . . . . . . . 25

General Senior Secondary Education Curriculum Structure ............. 28

Vocationalized Education . . . . . . . . . . . . . . . . . . . 29

5 Technical and Vocational Education and Training. ............... 33

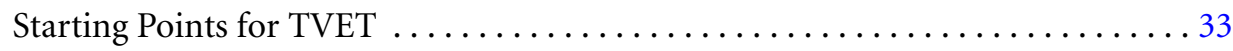

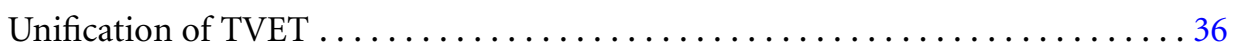

Qualification Frameworks and Integration. . . . . . . . . . . . . 36

Implications of Frameworks. . . . . . . . . . . . . . . . . 41

6 Operational Curriculum: Current Trends in Instructional Methodology . . . . . 43

The Need to Move Toward More Active Teaching and Learning Approaches . . . . . 43

Active Learning and Learner-centered Education $\ldots \ldots \ldots \ldots \ldots \ldots \ldots$

The Reality of Classroom Instruction and Learner-centered Education . . . . . . . 44

The Implementation of LCE. . . . . . . . . . . . . . . . . . 46

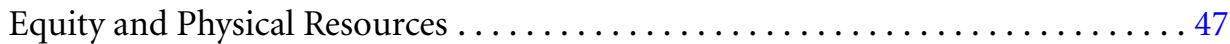

Further Curriculum Issues Influencing Instructional Quality $\ldots \ldots \ldots \ldots \ldots 48$

Curriculum, Teacher and Learner Support Materials ............... 51

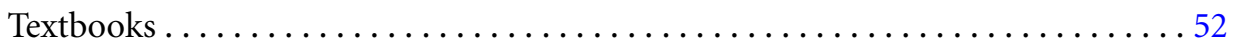

7 Attained Curriculum: Assessment and Assessment

Practices in Sub-Saharan Africa . . . . . . . . . . . . . . . . . . . . . 57

Assessment, Examination, and the Wider Picture $\ldots \ldots \ldots \ldots \ldots \ldots \ldots \ldots \ldots \ldots \ldots \ldots \ldots$

Examinations, Assessment, and the Curriculum ................. 57

Examination Results: Junior Secondary Level,

and Results of the TIMSS study ....................... 58

Examination Results Senior Secondary Level . . . . . . . . . . . . 60

Standard Setting and Quality Assurance of Secondary

Education Examinations................................ 60

Alignment Between Curriculum and Assessment ................6 62

Assessment Items and Examination Practices. . . . . . . . . . . . 62

Continuous Assessment and Assessment Instruments. . . . . . . . . . . . 64

Summary and Practical Suggestions for Examination and Assessment . . . . . . 65

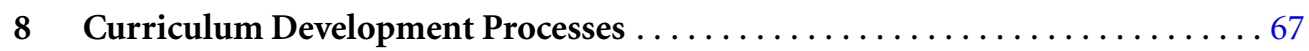

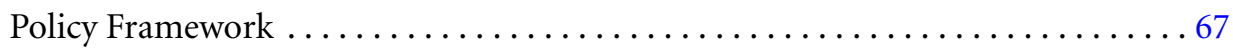

Addressing the Gap Between Plan and Achievement ............... 70

Considerations About Curriculum Implementation . . . . . . . . . . 72 
9 Capacity Building . . . . . . . . . . . . . . . . . . . . 79

The Need for Capacity Building in Sub-Saharan Africa . . . . . . . . . . . 79

Teacher Professional Development . . . . . . . . . . . . . . . . 79

Implementing In-service Education $\ldots \ldots \ldots \ldots \ldots \ldots \ldots \ldots \ldots \ldots \ldots \ldots \ldots \ldots \ldots \ldots$

Other Factors Influencing Implementation Education Reforms . . . . . . . . 84

Pre-service Teacher Education $\ldots \ldots \ldots \ldots \ldots \ldots \ldots \ldots \ldots \ldots \ldots \ldots$

10 Conclusions and Recommendations $\ldots \ldots \ldots \ldots \ldots \ldots \ldots \ldots \ldots \ldots \ldots \ldots \ldots \ldots \ldots \ldots$

Reform Potential and Focal Points $\ldots \ldots \ldots \ldots \ldots \ldots \ldots \ldots \ldots \ldots \ldots \ldots \ldots \ldots \ldots \ldots$

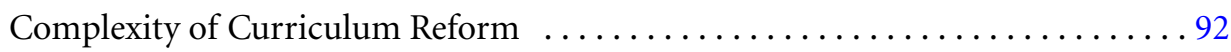

Curriculum Reform and Wider Educational Reform $\ldots \ldots \ldots \ldots \ldots \ldots$

The Importance of the Implementation Process, and the Technicalities

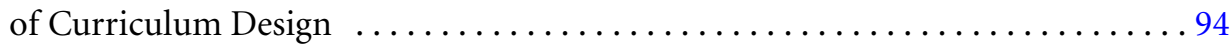

The Need for Capacity Development at All Levels . . . . . . . . . . . . . . 94

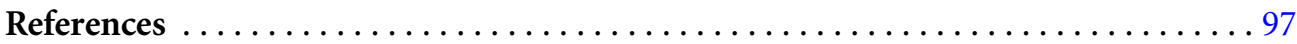

\section{LIST OF TABLES}

1. Enrollment in Junior Secondary Education in the Five Countries in the Study . . . 6

2. Enrollment in Senior Secondary Education in the Five Countries in the Study. . . . 6

3. Enrollment in Secondary Education in the Five Countries in the Study......... 7

4. Teachers and Student:Teacher Ratios in Selected Sub-Saharan African Countries. . 8

5. Curriculum Structures in Five Sub-Saharan Countries . . . . . . . . . . . 16

6. Exit Points, Continuation, and Exit Skills. .................. 18

7. Three Examples of Basic Education Curricula in Sub-Saharan Africa . . . . . . . . 23

8. Subjects and Learning Areas, Junior Secondary in Five Sub-Saharan Countries ... 24

9. Senior Secondary Curriculum Core Subjects and Options in Five Sub-Saharan Countries . . . . . . . . . . . . . . . . . . . . . . . . . . . . . . 30

10. Existing Links Between Education and Vocation in Sub-Saharan Africa . . . . . . 31

11. Levels of Physical Resources. ............................ 48

12. Examination Results Junior Secondary Level in Four Sub-Saharan Countries. .... 58

13. Examination Results at the Senior Secondary Level in Five

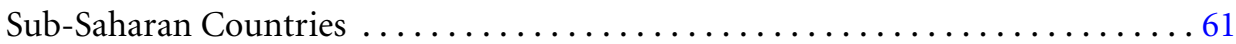

14. Curriculum Development Processes and Weights of Importance . . . . . . . . . 69

15. Potential Influence of Capacity Building on Individual and System Development. . . . . . . . . . . . . . . . . 80

16. Levels of Classroom Interaction, and Assessment . . . . . . . . . . . 82

17. Levels of School Management and School Ecology . . . . . . . . . . . . . 88 
vi Contents

\section{LIST OF FIGURES}

1. Primary Completion and Transition Rates, GER Secondary Education . . . . . . 7

2. Lengths of Educational Cycles .......................... 16

3. Different Exit Points into the World of Work $\ldots \ldots \ldots \ldots \ldots \ldots \ldots \ldots \ldots \ldots \ldots \ldots \ldots \ldots$

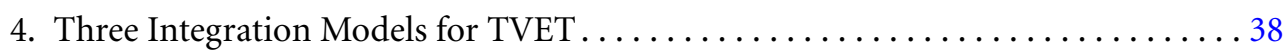

5. Attempted Qualifications Framework in Ghana .................... 39

6. The National Qualification Framework in South Africa............... 40

7. Selected TIMSS 2003 Results . . . . . . . . . . . . . . . . . . . . . . . . . . . 59

8. TIMSS 2003 international benchmarks for Math and Sciences . . . . . . . . . 60

9. FOI Interacting with Program and Context Characteristics. . . . . . . . 73

10. Shift from Centralization and Specification To Decentralization ............ 74 


\section{Foreword}

$\mathrm{M}$ any African countries are undertaking important economic reforms, improving macroeconomic management, liberalizing markets and trade, and widening the space for private sector activity. Where such reforms have been sustained they produced economic growth and reduced poverty. However, Africa still faces serious development challenges in human development, notably in post-primary education. The World Bank incorporated this within its Africa Action Plan (AAP) by underscoring the fundamental importance of expanding not only primary but also secondary and higher education, and linking it to employment options for African youth.

The Education for All-Fast Track Initiative (EFA-FTI) involves over 30 bilateral and international agencies and has made important strides. In the coming years, the key challenges are to consolidate progress towards universal primary education and expand secondary school access in response to economic and social demands. Secondary education and training are pre-requisites for increased economic growth and social development. It promotes productive citizenship and healthy living for young adolescents. To be competitive labor markets in Africa need more graduates with "modern knowledge and better skills." Asia and Latin America have shown these trends convincingly. However, expansion of post-primary education services while simultaneously improving its quality will require African countries to deliver these services more efficiently. Adoption of "innovative and best practices" from other Regions can help.

The "Secondary Education In Africa (SEIA)" study is part of the Africa Human Development Program that supports the Region's Africa Action Plan. Its objective is to assist countries to develop sustainable strategies for expansion and quality improvement in secondary education. The study program produced eight thematic studies, and additional papers, which were discussed at the regional SEIA conferences in which 38 countries and all major development partners participated (Uganda 2003; Senegal 2005; Ghana 2007). The SEIA Synthesis Report (2007) is a summary overview and discussion of all studies. All SEIA studies were produced with the help of national country teams and international institutions for which financial trust fund support is gratefully acknowledged. Study reports are available on the SEIA website: www.worldbank. org/afr/seia.

This thematic study is about curricula and assessment in Sub-Saharan Secondary Education. It is based on case studies in 10 African countries and a review of international literature by the Vrije University of Amsterdam and the University of Twente in the Netherlands. Both have been active in education in Africa for many years. The study confirms that secondary curriculum reforms are long overdue in Africa. The secondary curricula content is in most cases ill-adapted to 21 st century challenges, where young people are mobile, have competitive skills, and face health threats such as HIV/AIDS. Secondary curricula and assessment systems in Africa suffer in most cases from "severe overload," and outdated subject organization. Reforms efforts have been undertaken, but mostly led to "cosmetic" changes. This study analyzes that challenge: the quality of curricula and assessment and their development processes in secondary education in 
viii Foreword

Africa against the background of existing contexts, conditions, and ambitions on the one hand, and current pedagogical thinking on the other. I hope that this report will make a timely and useful contribution.

Jacob Bregman

Lead Education Specialist and SEIA Task Team Leader

Africa Region Human Development

The World Bank 


\section{Acknowledgments}

$\mathrm{T}$ his thematic study report on Curricula, Examinations, and Assessment in Secondary Education in Sub-Saharan Africa (CASASE) was prepared on a contractbasis by the Vrije University Amsterdam and the University of Twente (Netherlands) for the SEIA program of the Africa Region Human Development Department (AFTHD) in the World Bank. The CASASE study is SEIA Thematic Study \#5. This report was prepared with participation by national country teams in Tanzania, South Africa, Botswana, and Ghana, and Senegal. A seminar was organized by the two universities in Windhoek, Namibia in June 2005 with educators from these five African countries (and representatives from Namibia and Nigeria), and Jacob Bregman representing the SEIA team to discuss the structure and pedagogic approach of the report and the presentation of its outcomes.

The CASASE thematic study report was produced by Ramon Leyendecker and Dr. Wout Ottevanger from the Vrije University Amsterdam and Prof. Jan van den Akker from University of Twente in the Netherlands. Preliminary conclusions, methodology for the case studies and the overall objectives of this thematic study were presented at the third SEIA regional conference in Accra, Ghana, in April 2007. Comments from representatives of the country teams attending the conference were incorporated in the final version of this study. Linda Chisholm (South Africa) provided valuable feedback on the interims draft.

Earlier and final drafts of the CASASE study were also reviewed by Jacob Bregman (Task team leader SEIA, Lead Education Specialist, Africa Region, World Bank) and Adriaan Verspoor (Senior Education Consultant, Africa Region, World Bank). Kasha Klosowska (Education Consultant, Africa Region, World Bank) provided technical inputs and prepared the final draft for printing.

To prepare the study an extensive literature review was done and country visits organized to Tanzania, South Africa, Botswana, Ghana, and Senegal, in cooperation with partners in those countries. Interviews were conducted with national educators and curriculum specialists. A variety of country-specific documents were collected (policy papers, evaluation reports, international journal articles). Secondary schools and other educational institutions were visited and relevant staff interviewed. The contributions of all these stakeholders in SE are gratefully acknowledged.

This SEIA study was financed by the World Bank, the Norwegian Education Trust Fund (NETF) and the Dutch Government. Their support is gratefully acknowledged. 



\section{Executive Summary}

\section{Starting Point for Development: Access, Equity, Quality, and Curriculum}

Access impacts on curriculum where it impacts on quality, for example, rapid expansion of enrollment resulting in shortage of qualified teachers and lack of adequate physical structures. The employment of unqualified secondary school leavers as so-called "relief teachers" as a result of unplanned increases in access reduce the already low levels of teachinglearning activities in Sub-Saharan African classrooms.

Equity. While gender differences seem to have diminished over the last years, those associated with wealth have not. Children from the richest 20 percent of household have on average more than 11 times the chance to reach Grade 9 than those from the poorest households. Students in rural areas continue to experience disadvantages compared to those in urban areas. As general observations it seems that inequities in schooling represent inequities in society.

Quality. Curriculum reforms first and foremost should focus on improving the current teaching and learning processes. As a systemic challenge, these changes need to include re-orientation from secondary education as pre-academic tertiary education to a wider range of options, including vocational education and the world of work.

There is tension between increased access and quality as indicated by projections for the number of teachers needed to implement the proposed expansion. A more heterogeneous student population currently enters the secondary level in an expanded system. This requires acknowledgement of new demands on the teaching and learning strategies such as mixed ability teaching.

\section{Formal Curriculum and Curriculum Structures in Sub-Saharan Africa}

Length of secondary education varies across countries in Sub-Saharan Africa (SSA). Most common appears a structure in which secondary education starts in Grade 7 (after six years of primary education) and continues up to Grade 12, with three years of junior secondary followed by three years of senior secondary. There are many variations, including a Grade 13 option in most of the Francophone countries to accommodate the Baccalaureate. These arrangements tend to change from time to time based on new educational insights and political visions. Junior secondary education can be part of Basic Education (such as in South Ghana and Botswana), but is often an entity by itself (Tanzania, Senegal).

Position of TVET. With a limited intake capacity of tertiary education, SSA countries tend to stream their technical and vocational education (TVET), even though these currently exist only in a limited way. Educational reforms in SSA aim for more and better technical and vocational education. Social reputation of and demands for "white collar" TVET differ vastly with those of agriculture and "blue collar" TVET (technical and craftsmen) with business careers and ICT professions highly sought after, at all levels.

Exit skills marking the minimal learning outcomes required to proceed from one educational level to the next. Exit points are usually at the end of Primary, Basic Education 
(or Junior Secondary), and Senior Secondary. Table 6 provides an overview of exit skills and exit points in SSA.

Spiral Build-up of Curricula. Shortcomings at one level of education are often extended into the next level, as evidenced by the monitoring of learning in Botswana where achievement in numeracy and second language is low and carried over to the secondary level. It is observed that "spiral buildup of learning matter" in actual fact often means repeating the subject content from lower grades. In this respect it is important that clear exit skills are formulated so that this can be avoided, even though teachers often indicated that subject mastery is often so poor that re-teaching of content is absolutely necessary. A connected issue is that of integration of learning across learning areas. Although this may seem a good idea, the reality is that the same learning matter is taught in different subjects. Creating awareness for HIV and AIDS is one such topic that leads to repetition and duplicate teaching of the same content over and over again.

Language of Instruction. For the majority of students at secondary level language of instruction and the language used in examinations is not the mother tongue, but their second or third language. This is problematic, especially at junior secondary level, as there is strong evidence of a positive correlation of language proficiency and understanding. Formally, most countries use a bilingual language policy, with mother tongue instruction in the early years of primary education, changing to second language instruction (English or French mostly) around Grade 4. However, the classroom reality is that code switching is the norm, using both languages, depending on how well students appear to understand. South Africa (with 11 languages and sign language) has the most progressive and elaborate language policy, but has realized that implementation is a major problem. The bilingual policy has major implications. Language proficiency is an important entry requirement for learning at the secondary level. Students and teachers need to be proficient enough to use the instructional language at the secondary education level.

Subjects and Learning Areas in Junior Secondary. Current educational reforms in SSA organize subject content in core and optional subjects and in learning areas. The trend is to limit the number of possible subject combinations (to reduce curriculum overload, to facilitate active learning approaches, and to deal with limit availability of subject teachers). The trend is also towards a deeper (rather than broader) focus in the way content is dealt with and allow for personal development and maintenance of cultural and social cohesion. The integration of subject follows an international trend, but its implementation is not without problems as an integrated subject is usually taught by a number of individual teachers of subjects of which it is made up. For instance, integrated science is typically made up of biology, chemistry, and physics, and it is taught by the three teachers of those subjects. The lack of materials using an integrated approach is another hindrance to proper implementation.

Subjects and Learning Areas in Senior Secondary. Two basic senior secondary curriculum structures dominate in SSA, each subscribing to a different understanding of exit skills at the end of the secondary level. The first and wider-spread structure prescribes Language (either the local and the instructional language, or the instructional language only) and Mathematics as (part of) compulsory core subjects, with additional elective subjects optional for students to choose. The second structure (for example, in Tanzania) offers specialized and highly selective combinations of core courses of usually three subjects, which schools may define, and which define the school. The Senegalese SSE curriculum can be 
located in between the two structures. It offers different streams in the areas of languages, sciences, technical education, or commerce that consists of core subjects, but with different emphasis and time allocations; plus additional compulsory subjects for each stream, for example, philosophy for the languages. Although schools usually offer a large array of subject combinations, in practice some combinations dominate (sciences, business studies) with students streamed into these options based on their JSE examinations results.

Vocationalized education refers to a curriculum mainly academic in nature, but which includes vocational subjects in the timetable (JSE or SSE level). In contrast to TVET, it is part of general secondary education. SSA countries may wish to discuss continuation of vocationalized education in the light of:

The current perceptions and practices suggest that vocationalized subjects are for students from poor families.

Discontinuing vocationalized subjects relieves the pressure of an overloaded curriculum.

- Cost effectiveness: unit cost per students for vocationalized subjects are 2.5 to 4 times as high as compared to other subjects (in Botswana), 5.6 and 14.5 (Kenya) but much less high when compared to science classes (1.4 and 3.8 respectively).

Complex logistics of offering vocationalized subjects.

The need for sufficiently trained and competent teachers.

Technical and Vocational Education and Training (TVET). Across SSA, issues in TVET include:

TVET perceived as inferior to general secondary education.

Often TVET is separate from general secondary education, although now increasingly seen as part of it.

Entrepreneurship is seen as an important component of TVET to stimulate selfemployment.

There is a lack of clear standards for training, assessment and qualifications.

TVET requires flexibility from training for specific job to training for a specific occupational sector.

TVET in SSA is fragmented with many private providers offering training opportunities. The challenge for the sector is to unify it and to establish a system of quality assurance. A number of countries work on the development of a qualifications framework and have established parastatals for its organization and management, adding to already stretched human resources. In additional problem is that TVET is often the responsibility of more than one ministry, notably ministries of education and labor. To indicate the magnitude of the efforts required, Botswana has spent more than six years and extensive external support to establish a quality assurance system that covers part of its TVET program.

Qualification Frameworks. The existing or anticipated qualification frameworks are based on two determining models of differentiation based on two fundamentally different objectives:

They either attempt to encompass all primary, secondary, vocational, and tertiary education in one unifying framework to allow for mobility across all sectors (the 
NQF in South Africa), thereby not differentiating between TVET and academic education (as in Australia, Canada, England, New Zealand, and the United States). Or they attempt to differentiate curricula and institutions of TVET and of general education as a dual system (for example, Ghana). This model basically follows the German and Francophone practices, as in Senegal. The distinctions between the first exit point for continuation into TVET mark the differences within the model and the countries named.

All-inclusive qualification frameworks as contemporarily favored in many SSA countries and as part of SADC policies are political initiatives. Because of numerous systemic implications, they significantly complicate efforts to increase the quality of the formal curriculum, and blur the focus on the primary need to increase the quality of the curriculum in the classroom.

\section{Operational Curriculum: Curriculum in the Classroom}

Current Trends in Instructional Methodology. Recent curriculum reforms in SSA have focused on modernizing teaching methods in the classroom, away from teacher dominated classrooms to more active forms of learning. However, studies indicate that the implementation of active learning approaches is problematic and far removed from the ideal situation suggested in the curriculum documents. Classroom reality continues to be described in terms of dominant teachers, silent students, and chalk and talk. Reasons forwarded as to why this gap exists include cultural perceptions of what good teaching is, current inadequate levels of teachers' knowledge and practices, a general misunderstanding of the meaning of learner-centered education, and the shifting roles of teachers, resulting in implementation without the intended learning. Teachers, on the other hand, often forward the lack of physical resources, large classes and an overloaded curriculum as reasons for using teacher dominated classroom strategies.

Physical Resources. Facilities in schools in SSA are often sub-standard, especially in rural areas where the barest necessities for adequate teaching are lacking. Some countries, notably Ghana and South Africa, have introduced a system which channels larger portions of the available funding to less well endowed schools. In South Africa, the poorest 20 percent receive 35 percent of the resources. However, adequate physical resources increase the potential of a school, but it is acknowledged that eventually it is the teacher who will make the difference in the quality of instruction.

Time on Task. The limited time on task in SSA has a strong negative influence on learning opportunities. Reasons for a low time on task include a low allocation for teachers, absenteeism, lack of discipline, lack of teaching materials, and a large number of extracurricular activities. In South Africa teachers spend less on time on teaching (46 percent) than on administrative duties. Similar problems exist in SSA, especial in situations where curriculum reforms were being implemented.

Class Size. While large classes with 100 students or more is common in Junior Secondary classes, classes in Senior Secondary are usually much smaller, and often too small to be efficient. Generally, extreme class sizes point at inefficiencies in the system. 
Teacher Support Materials. Curriculum reforms in SSA advocate learner-centered teaching approaches. The changing role of teachers-from source of information to facilitator in the learning process - in such an approach requires support for teachers. Similar support is needed for new content in the curriculum. Studies, both SSA and internationally, have indicated that an effective way to structure this support is by providing exemplary teacher support materials as part of an in-service education scenario. This is in particular so in the initial stages of implementation. To be effective, support materials should:

Provide theoretical background information on the meaning of the change;

Demonstrate the practical meaning of the change;

Provide users with opportunities to experiment with exemplary activities, thereby gaining insight into the consequences of the change; and

Provide concrete resources that can serve as a frame of reference for the intended educational change.

Where such materials exist, there are persisting problems observed in most of visited SSA countries which illustrate that instructional materials will not necessarily and automatically achieve its potential for change. These include:

The distribution and availability of the learner support materials to schools;

The management, organization, and maintenance of the materials at the school level;

The opportunity for teachers to use the materials at school level; and

The will and capability of teachers to use the materials for pedagogically purposeful instruction.

Textbooks. In SSA secondary education, textbooks usually determine the depth and breadth of the curriculum. Quality of textbooks is therefore of utmost importance, both in terms of subject content and instructional processes. However, the latter part is often absent in textbooks as they mostly concentrate on content.

Textbooks are supplied free of charge (in Botswana) or are paid by the parents. Cost recovery through rental schemes have failed because of (amongst others) poor management.

Most SSA countries now have a system whereby publishers, both local and international, often working in partnership, produce and supply the textbooks. The issue of textbooks has produced calls for African publishers. In some countries and in some subjects, for example in Nigeria and Ghana, science and math teachers associations have teamed up with a local and international publishers.

Textbook selection is usually carried out by committees set up by the Ministry of Education. Selection processes should be transparent and base the selection process on adequate guidelines, but-because of the high stakes_often this is not the case and limits the productions-distribution process of textbooks. Senegal requires approval by two panels to counter corrupt practices.

Supply is problematic, especially to rural where books often do not reach the schools (especially if supplied by commercial publishers), and if they do, they are damaged, partly lost in transit or diverted to other schools. Once at the schools, books are often kept in its original box because of lack of a proper system to distribute them, or for fear of damage. The number of books available to students seems to have unacceptably declined over the last few years. 


\section{Attained Curriculum: Assessment and Assessment Practices}

Secondary education in SSA is dominated by examinations. Students write examinations at the end of a topic, end of term, the end of the year, as well as final national examinations at the end of junior secondary and senior secondary education. Educational outcomes in SSA are measured by the results of the examinations. Students, teachers, and schools derive their credit from examination results. "Teachers teach for examination success" is the often-heard phrase in SSA. The result is that teachers train students to reproduce facts and definitions, leading to rote-learning. Analysis of junior secondary examination results in the visited countries show that students generally pass in the lowest categories. Achievement in the higher cognitive domain is considered problematic. The TIMMS 2003 study (measuring mathematics and science abilities in Grade 8, first grade of junior secondary) in which Botswana, South Africa, and Ghana represented SSA positioned the three counties at the bottom of the list, way below the international average and well below the North African countries Morocco, Tunisia, and Egypt.

In examination results at senior secondary education, achievements are mostly in the lower and middle range. However, the value of the examination results must be seen in the light of measures taken by universities in many of the countries to establish entry examinations. This queries both the quality of the examination as well as the trustworthiness of the results of the exams. There are numerous reports of leakages in the examination system and fraudulent practices.

Most SAA countries have localized curricula, and localized examinations, or are in the process of localization. Namibia and Botswana have kept ties with the University of Cambridge Examination board to ensure appropriate standard setting in their SE examinations. Ghana and Nigeria conduct their examinations under the auspices of the West African Examination Council (WAEC). South Africa has re-established a quality assurance board for secondary education (Umalusi), and in 2005 has compared the standard of its examination questions against Scottish standards because the increases in pass rates in South Africa since 1994 have raised concerns.

Current curriculum reform activities in SSA countries are not always matched by reforms in assessment practices. The lack of alignment between curriculum and assessment is seen as a hindrance to efforts to implement modern teaching and learning practices as intended. The lack of alignment can be attributed to the lack of communication and cooperation between agencies at the national level, It also indicates problems with institutional capacities in many SSA countries.

Continuous assessment is more and more executed as a way to test achievement at school level, especially of skills. However, in reality it appears to more of the same written test for knowledge, sometimes understanding. Interestingly, in Nigeria students call CASS "Continuous Harassment."

At a technical level, SSA countries face practical problems that often stand in the way of implementing more adequate assessment strategies. In addition to questions of logistics, alignment, professionalism and accountability, other assessment and examination challenges include:

The definition of standards and accepted levels of performance;

Differentiation between standard (core) and higher grade;

New forms of assessment of skills, particularly as part of continuous assessment (CASS); 
Improvements in the quality of examinations, especially in the area of assessment items, and training for those setting these items;

Improvements in moderating and monitoring, professional development and building capacity in the examination system;

Sensitivity to language problems of students; and

Statistical analysis of the examination results to provide feedback on progress and effectiveness of the implementation of the curriculum.

The introduction of new and reliable assessment instruments need to be supported by professional development programs (both in in-service scenarios and in pre-service teacher education programs) in support of teachers introducing them. The suggestion in SSA for portfolio assessment in secondary education needs to be viewed with the necessary care, as the implementation of this will be a daunting task.

\section{Curriculum Development Processes}

In spite of the intentions expressed in past and current curricula, the outcomes have so far been well below expectations. This is in line with general observations of curriculum reform, both in SSA and internationally, that is described as the gap between ideals and outcomes, between rhetoric and reality.

Important conditions for a successful implementation of curriculum reforms include:

Acknowledgement of the complexity of curriculum development processes involving many stakeholders and different system levels;

Political will and social consent and widespread agreement from all stakeholders, over prolonged periods of time;

Realistic level of ambition and formulation of achievable objectives; and

Emphasis of curriculum development process to include analysis, design as well as implementation. Past orientations have mostly been on developing policies and plans, but have focused little on implementation.

\section{Addressing the Gap Between Plan and Achievement}

Realistic Timelines. Political pressures often dictate short timelines, leading to limited design possibilities and often little attention for implementation, professional development and capacity building. The C2005 curriculum in South Africa is a case in point. However, some countries have learned from the past and have set much more adequate timelines (for example, Botswana and Senegal).

Systemic Alignment. Curriculum development units (either parastatal, or ministerial departments) have the responsibility for curriculum development. Their roles is often restricted to syllabus writing, although sometimes in-service education activities are part of the mandate, but these are not always carried out due to lack of capacity, accountability or professional culture. Work is often carried out in isolation. Better communication structures with relevant institutions (examinations, teacher education, inspectorate), combined with clear formulation and distribution of responsibilities, will contribute to systemic alignment. Observations in this study suggest that adequate ICT structures can help in this process and more generally can address the complexities of curriculum development. 


\section{Curriculum Implementation}

Fidelity of Implementation. Internationally, more and more attention is given to curriculum adaptation and school-based curriculum development, within the confines of a national curriculum. Such a system of decentralized curriculum development seems currently outside the possibilities of SSA countries due to the absence of enough well qualified and experienced capacity for curriculum development, inspectorate and teaching.

Formative Evaluation. A shift in emphasis to a more implementation orientation in curriculum development should include formative evaluation as part of the analysis, design and implementation process. The focus of formative evaluation is on the quality criteria of relevance, curriculum consistencies, practicality in implementation, and effectiveness of the prototype curriculum.

Development research has been successfully employed as part of curriculum development, both internationally and in SSA. It serves the following purposes in the curriculum development processes:

Optimization of the development of prototypical products including provision of empirical evidence for their effectiveness;

Generation of methodological directions for the design and evaluation of such products; and

Contributing to the body of knowledge, and thereby increasing systemic capacity.

\section{Upscaling}

In recent years, a number of efforts for large-scale curriculum changes have been attempted in Africa (Namibia, South Africa), or are about to be attempted (Ghana, Senegal, Tanzania, Uganda). Evaluations of attempts to introduce large-scale curriculum reforms in SSA indicate a number of common findings. While the aims of the intended curriculum changes were and still are noble and valid in themselves, the changes have hardly made it into the classroom. The following list indicates the main factors for the shortcomings, many of them known by now:

The intended change was too far-reaching to be bridged in one step, beyond the capacity of the system, and too ambitious.

Not enough time was provided and not enough technical expertise was used in the initial analysis and design of the curriculum.

Lack of clarity of the meaning of the curriculum reform, a rushed implementation and lack of instructional materials.

Inadequate professional development infrastructure.

\section{Conclusions and Recommendations}

\section{Reform Potential and Focal Points}

Against the background of the goals of Equity, Access and Quality in education, two major ambitions drive contemporary curriculum reform attempts in SSA:

Better and more appropriate, relevant student' learning; and

Expanding and restructuring of secondary education, also to include TVET as part of educational opportunities. 
Curriculum reform has the potential to fully respond to the aim for better learning, and to partly respond to the restructuring of SE. Reform can increase curriculum quality mainly in the following areas:

The formal curriculum: the design of the form and content of the written curriculum frameworks and materials.

The implemented curriculum: the curriculum development and implementation processes, and the curriculum enacted in the classroom. The implemented curriculum, particularly the improvement of the quality of the instructional process ("teaching"), is the most important factor for achieving better learning.

The restructuring of secondary education to change its traditional routing-from entry to academic tertiary education to more technical and vocational education-demands the extension, unification, and integration of TVET. The task for more and better TVET involves in many countries the establishment or re-establishment of the complete sector. To limit an already enormous task, it is recommended to base the change on existing TVET contexts. The selection of the model for differentiation and integration of TVET should be based on realistic and practical considerations. The theoretical appeal of highly integrative integration frameworks, for example, the NQF in South Africa and other countries, is not matched by realistic outcomes, and the numerous practical problems originating from it.

To realize its reform potential, changes need to extend into the context and framework in which the curriculum operates. The focal points for curriculum reform for most countries in SSA are:

The complexity of curriculum reform, and the uniqueness of each reform attempt; Curriculum reform as the central part of educational reform, including the need to gain consent and agreement from society and the educational field for and on the reform;

The importance of the implementation process, and the technical process of curriculum design and development;

The need for capacity building and professional development at all levels, but especially in support of teachers implementing the reforms in their classrooms; and

The need to further develop organization and management of institutions in education, alongside and in interaction with curriculum reform.

\section{Complexity of Curriculum Reform}

Curriculum reforms in SSA require comprehensive approaches directed at the complexity of the educational system at large. It requires the acknowledgement of past obstacles and current challenges to reform, as well as the challenges additionally created by the reforms.

Human and physical resources, perceptions, experiences with past reforms and current school and classroom practices determine the limits of what educational systems can absorb in terms of development. Many high political ambitions have implications that are beyond current context and conditions. It therefore makes sense to have realistic ambitions and scope of curriculum reform, because these may increase the potential for successful implementation. Sometimes, less could actually be more. It is recommended that curriculum reform and strategies be based on the realities on the ground and much less on political ambitions. 
The resources (structures, instructional materials, textbooks, but also number of staff and their qualifications) available at schools to a large extent determine the learning conditions, and therefore the learning potential. Disadvantaged schools carry higher burdens. However, it is the active or passive quality of school cultures that are equally determining for learning. Many schools inside and outside of SSA show that:

Actively managed schools can alleviate disadvantages and make a difference (although a minimum level of resources is an elementary prerequisite);

Advantaged schools gain little with passive school cultures; and

Advantaged schools with active school cultures have the greatest benefit by far for students' learning.

It is recommended that physical resources be provided on a poorest-schools-first basis, to equalize conditions and to enable quality learning, while focusing on development of teacher capacity and school cultures.

\section{Curriculum Reform and Wider Educational Reform}

Coordination of Efforts. Implementation of curricula depends on improved coordination of development efforts with a focus on curriculum. The strong hierarchical structures in education in some SSA countries limit the communication between organizations so needed to tackle the complex tasks of curriculum development. It is recommended to increase the efficiency, clearly define institutional responsibilities, and provide for more and better cooperation and communication with and across existing institutions and departments. Site observations in SSA have shown that those organizations with wellworking ICT facilities are better prepared to respond to the management requirements of complex reforms.

Curriculum Consistency. Curriculum consistencies increase the scope of learning and learning potential. Three areas are of particular interest for contemporary curriculum reform in SSA:

Learning achievements at the primary level provide a strong base for learning at the secondary level; or in reverse, failures will extend into the secondary level and accumulate. Ensuring exit skills at the end of an educational cycle is vital for continuation in education (either academic or vocational), and suggests to design down the curriculum from higher levels to lower ones.

The issue of proficiency in the instructional language at the secondary education is a major obstacle to learning for most students in SSA. It deserves high attention and remedial interventions that need to include, mainly for Anglophone countries, the instructional language proficiency of teachers. Present approaches to instructional languages and bi-lingualism suggest the use of mother tongue instruction during the first years of primary education to provide for basic literacy skills, after which there is a transition to learning and using the second language as a medium of instruction.

Building learning potential on prior learning and across educational levels requires the spiral and age-relevant build-up of related subject matter across syllabi. It is 
recommended that curriculum designers communicate and cooperate across educational levels.

Socio-Political Influences. The more technical component of implementation cannot function without acknowledgement of its socio-political influence. Many factors determining curriculum reform are fluid variables depending on the societal context, influencing the societal context, and being influenced by the societal context. Not all of these variables can be completely influenced by curriculum designers.

Accountability. Ultimately, better learning and teaching depends on increased accountability at all levels of the educational and the political system. At the classroom level, a distinction needs to be made between the job side of teaching, and the professional side of it. Increasing accountability in classrooms cannot be achieved through pressure only, teachers also need to be supported and acknowledged.

\section{The Importance of the Implementation Process, and the Technicalities of Curriculum Design}

Implementation Perspective. Current curriculum reforms and larger educational reforms, of which they are part of, focus to a large extent on ambitions and on the "intended" part of the curriculum. "What" shall be achieved, and "what" must be done is clearly spelled out in policies and documents. Often even the specifications ("how") are detailed and backed up by literature and worldwide experiences. Yet, the actual and resulting accomplishments made in reality differ widely from initial intentions. This is largely because of the lack of a focus on implementation of the reforms. It is recommended that curriculum is developed using an implementation perspective. The adage should be "think big, start small.”

Development Research in Support of Curriculum Development. There are good experiences with curriculum development exercises that have embraced research as part of the development process. Development research typically consists of: (1) an analysis of state-of-the-art knowledge from the literature and of examples from similar contexts; (2) development of prototypes of the curriculum; (3) iterative process of design and formative evaluation; and (4) a summative evaluation to gauge effectiveness of the curriculum in terms of achieving learning objectives. During development, research typically moves its focus from validity and relevance of the intended curriculum (how relevant are the changes for the student and for subject learning) to issues of practicality (how feasible is it for teachers to implement the new curriculum in the classroom without changing their usual teaching practice too much) to measuring effectiveness (how well do students achieve the learning objectives of the new curriculum).

Exemplary Teacher Support Materials. Quality teacher (and student) support materials have a strong potential for implementation. It is suggested that professional developers together with experienced teachers produce such support materials for teachers to facilitate the complex forms of modern pedagogy. In several countries in SSA, exemplary materials have been developed as part of research guiding the development of the new curriculum. SSA regional cooperation may successfully share developed materials, or share the efforts for their development. 


\section{The Need for Capacity Development at All Levels}

Teacher knowledge and practices are the primary factors affecting the improved students' learning outcomes. The change in instructional processes depends on teachers' professional development, which is has a direct positive effect on teachers' knowledge and practices. Technical sound curriculum design (curriculum consistency), implementation-oriented curriculum development, alignment of curricula with assessment and examinations, and the interaction between all factors further influence instructional practices. The quality of co-operation between educational functions (curriculum development, assessment, in-service, evaluation) affects the feasibility and quality of educational reform. Professional developments in all sections of the educational system support the technical and managerial capacity of the educational system at large, and will increase the potential of curriculum reform.

Teacher Professional Development. Changing teachers' classroom practices does not work by replacement, but by incremental change over sustained periods of time supported by coaching activities of peers, heads of department and external agencies. Teachers' current beliefs and practices cannot simply be substituted but they can be build-upon towards better instructional quality and better fitting methodologies. Teacher professional development is key to more successful curriculum implementation and better student learning.

Job and Professional Standards. Professionalization cannot be mandated, but requires organizational learning and incremental change. Modeling the change is of high value for learning. Adherence to, first, job standards, and secondly professional standards, strongly contribute to professionalization. It is recommended to promote and model high levels of accountability for job standards. It is further recommended to facilitate the definition of professional standards by teachers or teacher organizations.

Capacity Building for Staff of Curriculum Development Units and Examination Agencies. Besides professional development programs for teachers, similar programs for other relevant staff in the education system would be hugely beneficial to efforts of curriculum reform. Such development programs are often attached to national curriculum development activities on an ad hoc basis. There are also examples in SSA where this happens in a structured way. For instance, at the University of Dar es Salaam there is a two year professional MEd program to train staff of ministries, curriculum development units and examination agencies.

External Support to Implementation. Many Western countries have decades of experience with active learning approaches. Over the years, and across SSA, small to mediumscale professional development activities tapping these experiences have shown to make a positive difference for classroom instruction in SSA. Provided that appropriate requirements are met, external experience can contribute to capacity building and professional development in SSA. 


\section{Résumé analytique}

\section{Point de départ pour le développement : accès, égalité, qualité et programmes scolaires}

L'accès a un impact sur les programmes lorsqu'il affecte la qualité, par exemple lorsque l'augmentation du nombre des inscriptions résulte en une pénurie d'enseignants qualifiés et en une insuffisance de structures matérielles. L'embauche d'enseignants non qualifiés fraîchement issus de l'enseignement secondaire en tant que "remplaçants ", suite à des augmentations non planifiées de l'accès, réduit le niveau déjà faible des activités d'enseignement et d'apprentissage dans les classes de l'Afrique subsaharienne.

Egalité : même si les disparités entre les sexes semblent avoir diminué ces dernières années, on ne pourrait en dire autant de celles associées à la richesse. Les enfants issus des $20 \%$ de ménages les plus riches ont en moyenne au moins 11 fois plus de chances d'atteindre la neuvième année que ceux qui sont issus des ménages les plus pauvres. Les élèves des milieux ruraux continuent à être désavantagés par rapport à ceux des milieux urbains. De façon générale, il semble que les inégalités scolaires sont représentatives des inégalités sociales.

Qualité : les réformes des programmes scolaires doivent en priorité se concentrer sur l'amélioration des processus actuels d'enseignement et d'apprentissage. En tant que défi systémique, ces changements doivent prévoir la réorientation de l'enseignement secondaire, aujourd'hui essentiellement considéré comme une préparation à l'université, vers l'intégration d'un plus large éventail d'options, incluant l'enseignement professionnel et le monde du travail.

Il existe une tension entre l'amélioration de l'accès et la qualité de l'enseignement, comme l'indiquent les projections du nombre d'enseignants nécessaires au développement envisagé. La plus grande hétérogénéité de la population d'élèves qui intègre le secondaire exige, dans un système en expansion, de reconnaître de nouvelles exigences en termes de stratégies d'enseignement et d'apprentissage, telles que la pédagogie différenciée.

\section{Les programmes scolaires officiels et leurs structures en Afrique subsaharienne}

La durée de l'enseignement secondaire varie selon les pays de l'Afrique subsaharienne. La structure la plus répandue semble être celle où l'enseignement secondaire commence en septième année (après six années d'enseignement primaire) et se poursuit jusqu'en douzième année, avec trois ans de premier cycle, suivis de trois ans de deuxième cycle. Il existe de multiples variations, notamment dans la plupart des pays francophones où une treizième année est souvent prévue pour préparer le baccalauréat. Ces dispositions tendent à changer de temps à autre en fonction de nouvelles approches d'éducation ou visions politiques. Le premier cycle de l'enseignement secondaire peut être intégré à l'enseignement fondamental (comme au Ghana du Sud et au Botswana), mais le plus souvent, il forme une entité distincte (Tanzanie, Sénégal) (Sections 4.1 et 4.2). 
Position de l'EFTP - Avec un enseignement de troisième cycle aux capacités d'absorption limitées, les pays d'Afrique subsaharienne ont tendance à répartir les matières qui relèvent de l'EFTP (Enseignement et formation techniques et professionnels), même si celles-ci n'existent actuellement que de façon limitée. L'objectif des réformes de l'enseignement en Afrique subsaharienne est d'augmenter et améliorer l'enseignement technique et professionnel. Le statut social et la demande d'EFTP de type «col blanc » diffèrent du tout au tout de ceux de l'agriculture et de l'EFTP de type « col bleu » (formation technique et métiers manuels) - les carrières en entreprise et les professions de type TIC (technologies de l'information et de la communication) étant très recherchées, à tous les niveaux (Section 4.3).

Les compétences de fin de cycle précisent les résultats minimaux d'apprentissage nécessaires au passage d'un cycle d'enseignement au suivant. Les fins de cycle se situent généralement à la fin du primaire, de l'enseignement fondamental (ou du premier cycle secondaire) et du deuxième cycle secondaire. Le tableau xx offre un aperçu des compétences de fin de cycle et des fins de cycle en Afrique subsaharienne (Section 4.4).

Développement en spirale des programmes scolaires - Les lacunes d'un niveau d'enseignement se répercutent souvent sur le suivant, comme le démontre le suivi de l'apprentissage au Botswana, où les niveaux de réussite en arithmétique et en deuxième langue sont faibles au niveau primaire et se retrouvent au secondaire. Dans les faits, on observe que le " développement en spirale des matières d'enseignement » implique souvent une répétition du contenu des matières des niveaux inférieurs. Pour éviter ce phénomène, il est donc important de définir clairement les compétences de fin de cycle, même si les enseignants affirment régulièrement que la maîtrise des matières est souvent tellement faible que la répétition de leur contenu est absolument nécessaire. L'autre question, liée à la précédente, est celle de l'intégration de l'apprentissage à travers les différents domaines d'enseignement. Même si l'idée semble bonne, en réalité, un même contenu reste souvent enseigné dans différentes matières. On sensibilise les élèves à la question du VIH et du SIDA, par exemple, en répétant plusieurs fois et dans plusieurs cours un contenu identique (Section 4.5)

Langue d'enseignement - Pour la majorité des élèves du secondaire, la langue d'enseignement, de même que celle qui est utilisée lors des examens, n'est pas leur langue maternelle mais une deuxième, voire un troisième langue, ce qui pose problème, surtout pour le premier cycle du secondaire, puisqu'il existe une corrélation positive prouvée entre maîtrise d'une langue et compréhension. Officiellement, la plupart des pays ont une politique de bilinguisme, l'enseignement en langue maternelle dans les premières années du primaire étant suivi d'un enseignement dans une deuxième langue (anglais ou français le plus souvent) autour de la quatrième année. Cependant, la réalité des salles de classe est que le jonglage entre les codes reste la norme et que, selon le niveau de compréhension des élèves, l'utilisation des deux langues est fréquente. C'est en Afrique du Sud (où coexistent 11 langues, langage des signes compris) que la politique linguistique est la plus progressiste et élaborée, même si l'on y réalise combien sa mise en œuvre est problématique. La politique de bilinguisme a d'importantes implications : la maîtrise de la langue est une condition d'entrée essentielle pour l'apprentissage dans le secondaire ; en outre, élèves et enseignants doivent suffisamment la maîtriser pour qu'elle puisse être utilisée comme un outil pédagogique dans le secondaire (Section 4.6). 
Matières et domaines d'apprentissage dans le premier cycle de l'enseignement secondaireLes réformes actuelles de l'enseignement en Afrique subsaharienne répartissent le contenu des cours entre matières de base et en option, et entre les domaines d'apprentissage. La tendance est à la limitation du nombre de combinaisons de matières possibles (afin d'éviter la surcharge du programme, de faciliter les approches d'apprentissage actif, et pallier le manque d'enseignants dans les matières concernées). La tendance est aussi à l'approfondissement (plutôt qu'à l'élargissement) de la manière dont les contenus sont traités, au développement personnel et au maintien d'une cohésion culturelle et sociale. Si l'intégration des matières relève d'une tendance internationale, sa mise en œuvre n'est pas sans difficulté étant donné qu'une matière "intégrée » est généralement enseignée par les enseignants d'un certain nombre de matières qui la constituent. Par exemple, les sciences intégrées incluent généralement la biologie, la chimie et la physique, et sont enseignée par les enseignants de chacune de ces trois matières. Le manque de supports didactique appliquant une approche intégrée est un autre obstacle à une mise en œuvre adéquate.

Matières et domaines d'apprentissage dans le deuxième cycle de l'enseignement secondaireLes deux structures qui dominent les programmes scolaires du deuxième cycle secondaire en Afrique subsaharienne correspondent chacune à une approche différente des compétences de fin de cycle secondaire. La première, qui est aussi la plus répandue, préconise l'apprentissage de la langue (langue parlée localement et langue d'enseignement, ou langue d'enseignement uniquement) et des mathématiques comme tout ou partie d'un tronc commun de matières obligatoires, avec la possibilité, pour les élèves, de choisir des matières optionnelles supplémentaires. La seconde structure, dont la Tanzanie est un exemple, offre en tronc commun des combinaisons spécialisées et très sélectives de cours de base (trois en général), définies par les établissements eux-mêmes et qui caractérisent ceux-ci. Le programme scolaire du deuxième cycle secondaire au Sénégal est à mi-chemin entre ces deux structures. Il offre différentes filières en langues, sciences, enseignement technique ou commerce, avec un tronc commun accordant aux matières, selon l'orientation, un niveau de détail et un temps différents. Il comprend également des matières obligatoires supplémentaires pour chacune filière, comme la philosophie pour les langues. Même si les établissements proposent généralement un large éventail de combinaisons de matières, dans la pratique certaines filières dominent (sciences, études commerciales), les élèves étant répartis entre ces options selon leurs résultats aux examens du premier cycle secondaire (Section 4.8).

L'enseignement professionnalisé consiste en un programme de nature essentiellement académique dont l'emploi du temps comprend des matières professionnelles (premier ou deuxième cycles secondaires). Contrairement à l'EFTP, il fait partie intégrante de l'enseignement secondaire général. Le débat sur la poursuite de l'enseignement professionnalisé dans les pays de l'Afrique subsaharienne devrait notamment prendre en compte des faits suivants :

Les perceptions et pratiques actuelles laissent supposer que les matières professionnelles sont destinées aux élèves des familles pauvres ;

La suppression des matières professionnelles permet de soulager un programme surchargé ;

Rentabilité : le coût unitaire par élève pour les matières professionnelles est de 2,5 à 4 fois plus élevé que pour les autres matières (au Botswana) et de 5,6 à 14,5 fois plus élevés (au Kenya), mais beaucoup moins élevés que pour les classes de science (de 1,4 à 3,8 fois moins élevés, respectivement) ; 
La complexité logistique de l'offre de matières professionnelles ;

Le besoin d'enseignants suffisamment bien formés et compétents (Section 4.11).

Enseignement et formation techniques et professionnels (EFTP) - En Afrique subsaharienne, différentes questions se posent à propos de l'EFTP :

L'EFTP est considéré comme inférieur à l'enseignement secondaire général ;

Il est souvent séparé de l'enseignement secondaire général, même s'il est maintenant de plus en plus considéré comme en faisant partie ;

L'esprit d'entreprise est considéré comme une composante décisive de l'EFTP, qui stimule l'initiative individuelle;

L'absence de normes claires en matière de formation, d'évaluation et de qualifications ; Le besoin de flexibilité : de la formation à un travail spécifique, à la formation à un secteur d'activité spécifique.

L'EFTP en Afrique subsaharienne est fragmenté sur un grand nombre de prestataires privés offrant des opportunités de formation. Pour le secteur, le défi est de s'unifier et d'établir un système d'assurance qualité. Plusieurs pays travaillent au développement d'un cadre de qualifications, organisé et géré par des parastataux, qui viennent s'ajouter à des ressources humaines déjà à la limite de leurs possibilités. Un autre problème vient du fait que l'EFTP dépend souvent de plus d'un ministère, notamment des ministères de l'Education et du Travail. A titre d'exemple des efforts à consentir, il a fallu plus de six ans, ainsi qu'un apport extérieur étendu, pour que le Botswana se dote d'un système d'assurance qualité couvrant une partie de son programme d'EFTP.

Cadres des qualifications - Les cadres des qualifications existants ou futurs s'inspirent de deux modèles déterminants de différentiation basés sur deux objectifs fondamentalement distincts :

soit ils cherchent, comme le NQF (National qualification framework ou cadre national des qualifications) sud-africain, à regrouper tout l'enseignement primaire, secondaire, professionnel et universitaire dans un cadre unique et unifié permettant la mobilité entre les secteurs, en ne différentiant pas EFTP et enseignement académique (comme par exemple en Angleterre, aux Etats-Unis, en Australie, au Canada ou encore en Nouvelle-Zélande);

soit ils cherchent à différencier les programmes et les institutions de l'EFTP et de l'enseignement général dans un système dual (comme au Ghana). Ce modèle s'inspire des approches allemande et francophone, comme au Sénégal. L'identification de la première fin de cycle permettant le passage vers l'EFTP constitue la différence essentielle au sein du modèle dans les pays concernés (Section 5.1-5.4).

Les cadres de qualifications exhaustifs, actuellement en faveur dans de nombreux pays d' Afrique subsaharienne ou dans le cadre des politiques de la SADC (Communauté de développement de l'Afrique australe), sont des initiatives politiques. À cause de nombre d'implications systémiques, elles compliquent considérablement les efforts d'amélioration de la qualité des programmes officiels et remettent en cause le besoin majeur d'améliorer la qualité des programmes dans les salles de classe. 


\section{Programme scolaire opérationnel - le programme scolaire en salle de classe}

Tendances actuelles en matière de méthodologie pédagogique - Les récentes réformes des programmes scolaires en Afrique subsaharienne se sont concentrées sur la modernisation des méthodes d'enseignement en salle de classe, en privilégiant les formes participatives d'apprentissage par rapport aux schémas traditionnels d'enseignement dominé par l'enseignant. Les études soulignent cependant que la mise en œuvre d'approches participatives est problématique et très éloignée de la situation idéale préconisée dans les documents des programmes scolaires. La réalité des classes reste caractérisée par le rôle prédominant de l'enseignant, des élèves silencieux et de l'exposé au tableau. Parmi les raisons avancées pour cet écart, on trouve la perception culturelle de ce qu'est un enseignement de qualité ; l'inadaptation actuelle du niveau des enseignants, tant du point de vue de leurs connaissances ou des pratiques; un malentendu généralisé sur ce que signifie « mettre l'élève au centre de l'apprentissage "; et l'évolution du rôle des enseignants que ceux-ci doivent assumer sans avoir reçu la formation adéquate. De leur côté, les enseignants font souvent état, pour justifier leur utilisation de stratégies centrées autour de l'enseignant, d'un manque de ressources matérielles, de classes trop nombreuses et de programmes surchargés (Sections 6.1-6.4).

Ressources matérielles - Les installations des établissements scolaires d'Afrique subsaharienne sont souvent inférieures aux normes, surtout dans les zones rurales qui ne disposent même pas du minimum requis pour permettre un enseignement correct. Certains pays, comme le Ghana et l'Afrique du Sud, ont introduit un système qui oriente une large part des financements disponibles vers les établissements les moins favorisés. En Afrique du Sud, les $20 \%$ d'établissements les plus pauvres reçoivent $35 \%$ des ressources. Même si des ressources matérielles adéquates peuvent effectivement accroître le potentiel d'un établissement, il faut bien reconnaître qu'au final, la qualité de l'enseignement dépend avant tout de l'enseignant (Section 6.5).

Temps réel d'activité - Le peu de temps réellement consacré à l'activité d'enseignement en Afrique subsaharienne a une influence très négative sur les opportunités d'apprentissage. Parmi les causes de ce faible temps d'activité, on trouve le nombre limité d'heures de cours attribuées aux enseignants, l'absentéisme, le manque de discipline et de supports pédagogiques, et le nombre important d'activités parascolaires. En Afrique du Sud, les enseignants passent moins de temps (46\%) à enseigner qu'à accomplir des tâches administratives. Il existe des problèmes similaires en Afrique subsaharienne, en particulier dans les situations où des réformes des programmes sont en cours de mise en œuvre.

Taille des classes - Si des classes de 100 élèves ou plus sont fréquentes au premier cycle du secondaire, elles sont habituellement moins nombreuses en deuxième cycle, et souvent trop réduites pour être efficaces. En général, des tailles de classes extrêmes de taille sont un symptôme du manque d'efficacité du système (Chapitre 6.6).

Supports pédagogiques destinés aux enseignants - Les réformes des programmes en Afrique subsaharienne plaident pour des approches qui placent l'élève au centre de l'apprentissage. Dans une telle approche, l'évolution du rôle des enseignants - d'une position 
où ils constituent la source des connaissances, à celle d'animateurs du processus d'apprentissage - exige que ceux-ci soient soutenus par un matériel pédagogique adéquat. Un soutien semblable est également nécessaire lorsque le contenu des programmes est modifié. Des études menées en Afrique subsaharienne et au niveau international ont montré qu'une des manières de structurer efficacement un tel soutien est d'offrir aux enseignants des supports pédagogiques modèles dans le cadre d'un scénario de perfectionnement. Il devrait en particulier en être ainsi dans les phases initiales de mise en œuvre. Pour avoir des effets concrets, ces supports pédagogiques doivent :

fournir l'arrière-plan théorique expliquant le changement ;

démontrer la signification pratiques du changement ;

donner aux utilisateurs des possibilités d'expérimenter les activités modèles, afin d'acquérir un aperçu des conséquences du changement ;

fournir des ressources concrètes pouvant servir de cadre de référence au changement envisagé en matière d'enseignement.

Lorsqu'un tel matériel existe, les problèmes qui subsistent dans la plupart des pays de l'Afrique subsaharienne illustrent le fait que les supports pédagogiques ne permettent pas forcément et automatiquement d'accomplir les objectifs du changement. Ces problèmes sont :

la distribution et la disponibilité des supports pédagogiques destinés aux enseignants dans les établissements ;

la gestion, l'organisation et la maintenance des supports au niveau des établissements ;

la possibilité pour les enseignants d'utiliser les supports dans les établissements ;

la volonté et la capacité des enseignants d'utiliser les supports dans le cadre d'un enseignement à but résolument pédagogique (Chapitre 6.7).

Manuels scolaires. Dans l'enseignement secondaire de l'Afrique subsaharienne, les manuels déterminent en général l'étendue et la profondeur du programme scolaire. C'est pourquoi la qualité des manuels scolaires est d'une importance capitale, tant en termes de contenu des matières que de processus pédagogiques. Ce dernier aspect est souvent absent des manuels, qui se concentrent principalement sur le contenu.

Les manuels sont fournis gratuitement (au Botswana) ou payés par les parents. La récupération des coûts à travers un système de prêt a échoué, (entre autres) du fait de la mauvaise gestion de ce système.

La plupart des pays d'Afrique subsaharienne se sont actuellement dotés d'un système où les éditeurs, tant locaux qu'internationaux, travaillent souvent en partenariat pour produire et fournir des manuels scolaires. La question des manuels a généré une demande au niveau des éditeurs africains. Dans certains pays et pour certaines matières - au Nigeria et au Ghana par exemple - les associations d'enseignants de sciences et mathématiques ont mis en place des collaborations avec des éditeurs locaux et internationaux.

La sélection des manuels se fait généralement par le truchement de comités mis en place par le ministère de l'Education. Les processus de sélection devraient rester transparents et se fonder sur des directives adéquates, mais les enjeux font que ce n'est pas toujours le cas et que les possibilités de production et de distribution des manuels scolaires restent 
souvent limitées. Le Sénégal lutte contre les trafics d'influence en exigeant l'accord de deux comités.

La fourniture reste un problème, surtout dans les zones rurales où il est fréquent que les livres ne parviennent pas jusqu'aux établissements (surtout lorsque le fournisseur est un éditeur commercial), et où, lorsqu'ils arrivent enfin à destination, les manuels sont abîmés, égarés pendant le transport, ou détournés vers d'autres établissements. Dans les établissements, en l'absence d'un système de distribution approprié ou parce qu'on craint de les endommager, les manuels sont souvent gardés dans leur boîte d'origine. Le nombre de livres disponibles pour les élèves semble aussi avoir diminué de manière inacceptable au cours des dernières années.

\section{Réalisation des programme scolaires : évaluation et pratiques d'évaluation}

L'enseignement secondaire en Afrique subsaharienne est dominé par les examens. Les élèves passent des examens à la fin d'un cours, à la fin d'un terme, à la fin de l'année, ainsi qu'au niveau national, à la fin du premier et du deuxième cycle de l'enseignement secondaire. Les résultats scolaires en Afrique subsaharienne sont mesurés d'après les résultats aux examens. Étudiants, enseignants et écoles tirent tous leur crédit des résultats des examens. «Les enseignants enseignent pour la réussite aux examens », entend-on souvent dire en Afrique subsaharienne. Il en résulte que les enseignants forment les élèves à reproduire des faits et définitions, ce qui les pousse au " par cœur». Dans les pays visités, l'analyse des résultats des examens du premier cycle secondaire montre qu'en général, les élèves sont tombés au niveau des catégories inférieures. Leurs acquis d'un niveau cognitif plus élevé semblent problématiques. Dans l'étude TIMMS 2003 (qui mesure les capacités des élèves de huitième année d'étude, la première année du premier cycle secondaire, en mathématiques et en sciences) où l'Afrique subsaharienne était représentée par le Botswana, l'Afrique du Sud et le Ghana, ces trois pays se sont classés en fin de liste, très en dessous de la moyenne internationale, et loin derrière le Maroc, la Tunisie et l'Egypte représentant l'Afrique du Nord (Chapitres 7.2-7.3).

En ce qui concerne les examens du deuxième cycle secondaire, les résultats vont de faible à moyen. L'évaluation des résultats aux examens doit néanmoins se faire à la lumière de ceux obtenus dans les universités de beaucoup de pays qui se sont dotées d'examens d'entrée. Ils posent la question de la qualité de l'examen et de la fiabilité des résultats des examens. On parle beaucoup de fuites et de pratiques frauduleuses au niveau du système d'examens (Chapitres $7.4 \& 7.5$ ).

Dans la plupart des pays de l'Afrique subsaharienne, les programmes scolaires et les examens sont localement adaptés, ou sont en passe de l'être. La Namibie et le Botswana ont gardé des liens avec l'University of Cambridge Examinations Board (le bureau chargé des examens de l'Université de Cambridge) pour s'assurer de l'adéquation de leurs examens aux normes de l'enseignement secondaire. Au Ghana et au Nigeria, les examens se déroulent sous les auspices du West African Examination Council (conseil ouest-africain des examens ou WAEC). L'Afrique du Sud a réinstauré un bureau d'assurance qualité de l'enseignement secondaire (Umalusi). En 2005, devant l'augmentation suspecte de ses taux de réussite depuis 1994, ce pays a comparé le niveau de ses questions d'examens avec celles de l'Ecosse (Chapitre 7.5). 
Les activités de réforme des programmes en cours dans les pays d'Afrique subsaharienne ne trouvent pas toujours d'équivalent dans les pratiques d'évaluation. L'absence de concordance entre les programmes et l'évaluation est considérée comme un obstacle aux efforts de mise en œuvre de l'enseignement et des pratiques d'apprentissage modernes envisagées. Cette absence de concordance est attribuable à un manque de communication et de coopération entre agences au niveau national. Elle souligne aussi les problèmes de capacité institutionnelle de nombreux pays de l'Afrique subsaharienne. (Chapitres $7.5 \& 7.6$ ).

On procède de plus en plus souvent à l'évaluation continue (CASS) pour tester les acquis des élèves dans les établissements scolaires, en particulier en matière de compétences. Dans la réalité cependant, il s'agit encore fréquemment de tests écrits des connaissances, et parfois de compréhension. Au Nigeria, il est symptomatique que les élèves traitent le CASS de « harcèlement continu » (Chapitre 7.8).

Techniquement, les pays d'Afrique subsaharienne sont confrontés à des problèmes pratiques qui font souvent obstacle à la mise en œuvre de stratégies d'évaluation plus adéquates. Au-delà des questions logistiques, de concordance, de professionnalisme ou de responsabilité, les défis auxquels il faut faire face en matière d'évaluation et d'examens sont :

la définition des normes et des niveaux de performance admis ;

la différenciation entre études générales (éducation de base) et études de plus haut niveau ;

les nouvelles formes d'évaluation des compétences, en particulier celles qui font partie de l'évaluation continue ;

les améliorations dans la qualité des épreuves, en particulier dans les domaines des questions d'évaluation et de la formation de ceux qui en décident;

les améliorations dans la modération et le suivi, la formation professionnelle et le développement de capacités en matière de systèmes d'examens ;

la sensibilisation aux problèmes de langage des élèves ;

l'analyse statistique des résultats d'examens pour fournir un feedback sur les progrès et l'efficacité de la mise en œuvre des programmes scolaires (Chapitre 7.7).

L'introduction de nouveaux instruments fiables d'évaluation doit être appuyée par des programmes de développement professionnel (dans le cadre de scénarios à la fois de perfectionnement et de préparation à l'entrée en fonction des enseignants) pour aider les enseignants chargés de les introduire. La possibilité d'une évaluation du portefeuille de l'enseignement secondaire en Afrique subsaharienne doit être envisagée avec toute l'attention qu'elle mérite, car sa mise en œuvre sera particulièrement ardue.

\section{Processus de développement des programmes scolaires}

En dépit des intentions exprimées dans les programmes passés et actuels, les résultats sont jusqu'à présent restés bien en deçà des attentes. Ceci est en accord avec l'observation générale qu'en matière de réforme des programmes scolaires, tant en Afrique subsaharienne qu'au niveau international, il y a un fossé entre idéaux et résultats, entre rhétorique et réalité : 
Conditions essentielles à la mise en œuvre réussie d'une réforme des programmes scolaires :

Reconnaître la complexité des processus de développement de programmes scolaires, qui impliquent un grand nombre de parties prenantes et différents niveaux de système.

Volonté politique, consensus social et accord élargi de toutes les parties prenantes, sur une période de temps prolongée.

Réalisme des ambitions et formulation d'objectifs susceptibles d'être atteints.

Accent mis sur le fait que le processus de développement des programmes scolaires doit prévoir une analyse, une conception et une mise en ouvre. Par le passé, la tendance a surtout été de développer des politiques et des plans, mais très peu de les mettre en œuvre.

\section{S'occuper des écarts entre plans et résultats}

Réalisme des délais. Les pressions politiques imposent souvent des délais raccourcis, ce qui réduit la réflexion sur la conception et l'attention accordée à la mise en œuvre, au développement professionnel et au développement des capacités. Le programme scolaire C2005 de l'Afrique du Sud en est un bon exemple. Certains pays comme le Botswana ou le Sénégal ont pourtant tiré les leçons du passé et se sont fixé des objectifs moins ambitieux en termes de délais.

Concordance systémique. Des entités (organismes parastataux, départements des ministères) sont responsables de l'élaboration des programmes scolaires. Leur rôle est souvent limité à la rédaction de syllabus. Des activités de perfectionnement de l'enseignement peuvent parfois faire partie de leur mandat mais cette tâche n'est pas toujours assumée à cause d'un manque de capacités, de responsabilité ou de culture professionnelle. Le travail est fréquemment effectué dans l'isolement. La mise en place de structures de communication mieux adaptées avec les institutions concernées (examen, formation des enseignants, inspections), ainsi qu'une formulation et une distribution claires des responsabilités, peuvent contribuer à une meilleure concordance systémique. Les observations faites par la présente étude indiquent que des structures TIC adaptées peuvent soutenir ce processus et, plus généralement, offrir des solutions aux questions complexes d'élaboration des programmes scolaires.

\section{Mise en ouvre des programmes}

Fiabilité de la mise en œuvre. Au niveau international, une attention de plus en plus soutenue est portée à l'adaptation des programmes scolaires et à leur développement au niveau des établissements dans les limites des programmes nationaux. Un tel système d'élaboration décentralisée des programmes semble actuellement dépasser les possibilités des pays de l'Afrique subsaharienne, en raison d'une absence de capacités et d'expérience qualifiée suffisantes en matière de développement des programmes, d'inspectorat et d'enseignement.

Evaluation formative. Un changement d'orientation en faveur de la mise en ouvre dans le processus de développement des programmes doit prévoir un volet d'évaluation formative dans les phases d'analyse, de conception et de mise en œuvre. 
L'attention de l'évaluation formative est concentrée sur les critères de qualité que sont la pertinence, les cohérences entre les programmes, l'aspect pratique de la mise en œuvre, et l'efficacité du prototype de programmes.

La recherche sur le développement a été utilisée avec succès comme élément du développement des programmes, tant au niveau international qu'en Afrique subsaharienne. Elle poursuit les buts dans les processus de développement des programmes :

Optimisation du développement de produits prototypes permettant d'apporter des preuves empiriques de leur efficacité ;

Définition d'orientations méthodologiques pour la conception et l'évaluation de ces produits ;

Contribution au corpus de connaissances et renforcement des capacités systémiques.

\section{Passage à l'échelle supérieure}

Ces dernières années, un certain nombre d'efforts ont été consentis (Namibie, Afrique du Sud), ou sont en passe de l'être (Ghana, Sénégal, Tanzanie, Ouganda) en faveur d'un changement à grande échelle des programmes. Les différentes évaluations des tentatives de réformes de ce type en Afrique subsaharienne ont fait un certain nombre de constatations communes. Même si les objectifs des changements de programmes étaient en eux-mêmes nobles et valables, leur application dans les salles de classe a été difficile. La liste qui suit fait le point sur les principaux facteurs responsables des déficiences, dont beaucoup sont désormais connues :

Le changement envisagé était de trop grande envergure pour être accompli en une étape, il dépassait les capacités du système, et était trop ambitieux ;

L'analyse et la conception initiales des programmes n'ont pas bénéficié du temps et de l'expertise techniques suffisants ;

La signification de la réforme des programmes n’a pas été clairement expliquée, la mise en œuvre précipitée et les supports pédagogiques insuffisants ;

L'infrastructure de développement professionnel était inadaptée.

\section{Conclusions et recommandations}

\section{Potentiel et points d'attention de la réforme}

Au-delà des objectifs d'égalité, d'accès et de qualité de l'enseignement, deux ambitions majeures guident les actuelles tentatives de réformes des programmes en Afrique subsaharienne :

L'amélioration de la qualité, de l'adéquation et de la pertinence de l'apprentissage des élèves ;

L'expansion et la restructuration de l'enseignement secondaire, avec une intégration de l'EFTP dans les opportunités éducationnelles.

La réforme des programmes scolaires a le potentiel pour satisfaire intégralement l'objectif d'amélioration de l'apprentissage, et partiellement celui de restructuration de l'enseignement 
secondaire. La réforme peut permettre d'améliorer la qualité des programmes principalement dans les domaines suivants :

Programmes scolaires officiels : conception de la forme et du contenu du cadre et des supports écrits des programmes;

Mise en œuvre des programmes : le processus d'élaboration et de mise en œuvre des programmes et l'application de ceux-ci dans les salles de classe. La mise en œuvre des programmes, et plus particulièrement l'amélioration de la qualité du processus pédagogique ( l'enseignement»), est le facteur le plus important d'amélioration de l'apprentissage.

Pour que le parcours traditionnel de l'enseignement secondaire puisse passer d'une orientation vers la préparation aux études supérieures à celle d'un apprentissage plus technique et professionnel, sa restructuration exigera l'extension, l'unification et l'intégration de l'EFTP. Dans de nombreux pays, la mise en place d'un EFTP plus complet et de meilleure qualité implique d'établir, ou de rétablir le secteur dans son ensemble. Afin de simplifier cette tache déjà immense, il est conseillé de s'appuyer sur les schémas d'EFTP existants. Le choix du modèle de différenciation et d'intégration de l'EFTP doit se fonder sur des considérations à la fois réalistes et pratiques. Si les systèmes fortement intégrés, comme le NQF en Afrique du Sud et dans d'autres pays, sont théoriquement séduisants, leurs résultats concrets ne sont pas à la hauteur et nombre de problèmes pratiques en résultent.

Pour réaliser pleinement leur potentiel de réforme, les changements doivent être étendus au contexte et au cadre de mise en ouvre des programmes scolaires. Pour la plupart des pays d'Afrique subsaharienne, les points d'attention de la réforme des programmes scolaires sont :

La complexité de la réforme des programmes et le caractère unique de chaque tentative de réforme ;

La réforme des programmes en tant qu'élément central d'une réforme de l'éducation, et en particulier la nécessité d'obtenir le consentement et l'accord de la société et du secteur pédagogique en faveur de la réforme et sur son contenu ;

L'importance du processus de mise en œuvre et du processus technique de conception et d'élaboration des programmes ;

- La nécessité de renforcer les capacités et la formation professionnelle à tous les niveaux, en particulier pour soutenir les enseignants qui appliquent les réformes dans leurs classes ;

La nécessité d'un renforcement de l'organisation et de la gestion des institutions de l'enseignement, concomitamment et en interaction avec la réforme des programmes.

\section{Complexité de la réforme des programmes}

La réforme des programmes en Afrique subsaharienne nécessite une approche globale tenant compte de la complexité du système éducatif dans son ensemble. Elle nécessite aussi une reconnaissance des obstacles passés et des difficultés actuelles auxquels est confrontée la réforme, ainsi que des défis générés par la réforme elle-même.

Les ressources humaines et matérielles, les perceptions, les expériences des réformes passées et les pratiques pédagogiques des établissements et dans les classes fixent les limites 
de ce qu'un système éducatif peut absorber en termes d'évolution. Beaucoup d'ambitions politiques ambitieuses ont des implications qui dépassent le contexte et les conditions actuelles. Il serait donc raisonnable de faire en sorte que les ambitions et l'envergure de la réforme des programmes restent réalistes, ce qui permettrait d'améliorer ses chances de réussite. Le mieux étant parfois l'ennemi du bien, il est donc recommandé de fonder les stratégies et réformes des programmes scolaires sur les réalités du terrain plutôt que sur des ambitions politiques.

Les ressources disponibles dans les établissements (exemples : structures, supports pédagogiques, manuels scolaires mais aussi le nombre de membres du personnel et leurs qualifications) déterminent dans une large mesure les conditions et par conséquent le potentiel d'apprentissage. Les établissements les plus désavantagés ont un fardeau plus lourd à porter mais le caractère actif ou passif de la culture des établissements est tout aussi déterminant pour l'apprentissage. Dans de nombreux établissements d'Afrique subsaharienne ou d'ailleurs, on constate que :

Les établissements gérés avec dynamisme arrivent à limiter leurs handicaps et à faire la différence (même s'il est évident qu'un niveau minimum de ressources est une condition aussi nécessaire qu'élémentaire) ;

Les établissements avantagés tirent peu de bénéfices d'une culture de passivité ;

Ce sont les écoles avantagées dotées d'une culture d'établissement active qui, de loin, tirent le plus de bénéfices en termes d'apprentissage.

Il est recommandé d'allouer les ressources matérielles en premier lieu aux écoles les plus désavantagées de manière à équilibrer les conditions et à favoriser un apprentissage de qualité, tout en ne perdant pas de vue le renforcement des capacités des enseignants et des cultures d'établissement.

\section{Réforme des programmes et réforme de l'enseignement en général}

Coordination des efforts : La mise en œuvre des programmes scolaires dépend de l'amélioration de la coordination des efforts de développement en général, avec une attention particulière portée aux programmes. La rigidité des structures hiérarchiques du système éducatif de certains pays d'Afrique subsaharienne restreint la communication entre organisations, si nécessaire pour s'attaquer aux tâches complexes d'élaboration des programmes scolaires. Il est conseillé d'améliorer l'efficacité, de définir clairement les responsabilités institutionnelles, et de renforcer et améliorer la coopération et la communication avec et entre les institutions et départements existants. Les observations sur sites réalisées en Afrique subsaharienne montrent que les organisations bien équipées en TIC sont mieux préparées à répondre aux exigences de gestion de réformes complexes.

Cohérence des programmes scolaires : la cohérence des programmes augmente la portée et le potentiel de l'apprentissage. Trois domaines sont particulièrement intéressants pour une réforme moderne des programmes :

Les acquis de l'enseignement primaire sont une base solide pour l'apprentissage au secondaire et, inversement, les lacunes du primaire s'étendent au niveau du secondaire et s'y accumulent. S'assurer des compétences à la fin d'un cycle scolaire est 
essentiel à la poursuite des études (qu'elles soient universitaires ou professionnelles) et exige donc de concevoir les programmes scolaires en partant des niveaux supérieurs vers les niveaux inférieurs;

Le manque de maîtrise de la langue d'enseignement au niveau du secondaire est un obstacle majeur à l'apprentissage pour la plupart des élèves d'Afrique subsaharienne. C'est là une question qui requiert la plus grande attention et toute intervention visant à y remédier doit tenir compte, dans les pays anglophones en particulier, de la maîtrise de la langue d'enseignement par les enseignants. Actuellement, les approches adoptées en matière de langue d'enseignement et de bilinguisme sont favorables à l'utilisation de la langue maternelle comme langue d'enseignement dans les premières années primaires pour permettre l'acquisition des connaissances de base. Une transition permet ensuite de passer à l'apprentissage et à l'utilisation de la seconde langue en tant qu'outil pédagogique.

La constitution d'un potentiel d'apprentissage en s'appuyant sur les acquis du niveau précédent exige de développer les syllabus des différentes matières en spirale et en fonction de l'âge. Il est conseillé aux concepteurs des programmes scolaires de communiquer et de coopérer à tous les niveaux de l'enseignement.

Influences sociopolitiques: La composante plus technique de la mise en œuvre ne peut fonctionner sans une reconnaissance préalable de ses influences sociopolitiques. Beaucoup des facteurs déterminants de la réforme des programmes scolaires sont des variables fluides, qui dépendent du contexte sociétal, influencent le contexte sociétal et sont influencées par lui. Les concepteurs des programmes scolaires ne peuvent pas forcément agir sur toutes ces variables.

Responsabilisation : L'amélioration de l'apprentissage et de l'enseignement dépend finalement d'une meilleure responsabilisation à tous les niveaux des systèmes pédagogique et politique. Dans les classes, il est important de faire la distinction entre l'aspect travail de l'enseignement et son aspect professionnel. Mettre la pression sur les enseignants ne peut en aucun cas suffire à accroître la responsabilisation au niveau des classes, les enseignants doivent aussi se sentir soutenus et reconnus.

\section{Importance du processus de mise en ouvre et aspects techniques de la conception des programmes}

Perspective de mise en auvre : Les réformes actuelles des programmes scolaires, et les réformes pédagogiques dont elles font partie, se focalisent en grande partie sur les ambitions et les « intentions » des programmes scolaires. "Ce » qui doit être réalisé et être fait pour y arriver est clairement explicité dans les politiques et les documents. Souvent, les spécifications (le « comment») y sont aussi détaillées et appuyées par la littérature ou des expériences tirées d'autres exemples internationaux. Dans la réalité cependant, les résultats concrets sont souvent très différents des intentions initiales, en grande partie à cause du peu d'attention portée à la mise en œuvre des réformes. Il est recommandé de développer des programmes scolaires dans une perspective de mise en œuvre. La devise devrait être « voir grand mais commencer petit».

Recherche en développement en appui à l'élaboration des programmes scolaires: Il existe des expériences positives d'exercices d'élaboration de programmes scolaires qui ont intégré la 
recherche dans le processus de développement. En général, la recherche en développement consiste en (1) une analyse de l'état des connaissances actuelles à partir de la littérature et d'exemples tirés de contextes similaires ; (2) le développement de prototypes de programmes scolaires ; (3) un processus itératif de conception et d'évaluation formative ; et (4) une évaluation sommative qui mesure l'efficacité des programmes scolaires en termes de réalisation des objectifs d'apprentissage. Pendant le développement, les priorités de la recherche se déplacent de l'analyse de la validité et de la pertinence des programmes scolaires concernés (le degré de pertinence des changements pour les élèves et pour la matière) vers leurs aspects pratiques (est-il possible que les enseignants mette en œuvre le nouveau programme dans leurs classes sans trop changer leurs méthodes habituelles d'enseignement ?), puis vers une évaluation de leur efficacité (à quel point les élèves ont-ils atteints les objectifs d'apprentissage des nouveaux programmes de cours?).

Supports pédagogiques modèles destinés aux enseignants: Des supports pédagogiques de qualité destinés aux enseignants (et aux élèves) peuvent contribuer de manière substantielle à la mise en œuvre. Il est conseillé que les développeurs professionnels produisent ce type de supports en collaboration avec des enseignants expérimentés pour faciliter l'accès des enseignants aux formes complexes de pédagogie moderne. Dans plusieurs pays d'Afrique subsaharienne, des supports pédagogiques modèles ont été développés dans le cadre de recherches guidant le développement des nouveaux programmes scolaires. La coopération régionale en Afrique subsaharienne devrait permettre un partage entre pays des supports développés ou des efforts de leur développement.

\section{Nécessité de renforcement des capacités à tous les niveaux}

Les connaissances et les pratiques des enseignants sont les principaux facteurs affectant l'amélioration des résultats des élèves. L'évolution des processus pédagogiques dépend du développement professionnel des enseignants, qui a lui-même un effet positif direct sur les connaissances et les pratiques de ces derniers. Une solide conception technique des programmes (par exemple leur cohérence), un développement des programmes axé sur leur mise en œuvre, l'alignement des programmes avec les évaluations et examens, et l'interaction entre l'ensemble des facteurs influence aussi les pratiques pédagogiques. La qualité de la coopération entre fonctions éducatives (exemples : élaboration des programmes, estimation, perfectionnement, évaluation) affecte la faisabilité et la qualité de la réforme de l'enseignement. Le développement professionnel dans tous les domaines du système éducatif soutient les capacités techniques et de gestion du système éducatif dans son ensemble, et accroissent le potentiel de la réforme des programmes.

Développement professionnel des enseignants : Faire évoluer les pratiques des enseignants dans les classes ne se fait pas à travers un simple remplacement, mais par un changement progressif étalé sur une longue période et soutenu par un accompagnement des pairs, des chefs de département et d'agences extérieures. Les convictions et les pratiques actuelles des enseignants ne peuvent pas être simplement remplacées, elles doivent servir de bases à la construction d'une meilleure qualité pédagogique et d'une plus grande adaptation de la méthodologie. Le développement professionnel des enseignants est une clef pour la réussite de la mise en œuvre des programmes de cours et l'amélioration de l'apprentissage des élèves. 
Normes de travail et normes professionnelles : La professionnalisation ne peut être simplement imposée par mandat, elle nécessite un apprentissage organisationnel et un changement progressif. Une bonne modélisation du changement est un atout de valeur pour l'apprentissage. L'adhésion à, d'une part, des normes de travail, et d'autre part, à de normes professionnelles contribue énormément à la professionnalisation. Il est conseillé de promouvoir et modéliser des niveaux élevés de responsabilisation pour les normes de travail. Il est également recommandé de faciliter la définition des normes professionnelles par les enseignants ou leurs organisations.

Renforcement des capacités du personnel des unités de développement des programmes et des agences chargées des examens : En plus des programmes de développement professionnel destinés aux enseignants, des programmes similaires conçus pour les autres personnels du système éducatif concernés devraient être extrêmement bénéfiques aux efforts de réforme des programmes. Ces programmes de développement sont souvent rattachés de manière opportuniste aux activités nationales de développement des programmes. Il existe néanmoins des exemples en Afrique subsaharienne où cela se fait de manière structurée. Par exemple, l'Université de Dar es Salam propose un programme professionnel MEd (Master en éducation) de deux ans destiné à former les membres du personnel des ministères, des unités de développement des programmes scolaires et des agences chargées des examens.

Soutien extérieur à la mise en œuvre: Beaucoup de pays occidentaux ont une expérience active de plusieurs décennies en matière d'approches d'apprentissage actif. Avec les années, et dans toute l'Afrique subsaharienne, les activités de développement professionnel à petite ou moyenne échelles inspirées de ces expériences ont prouvé qu'elles pouvaient faire une vraie différence pour la pédagogie dans les salles de classe en Afrique subsaharienne. À condition que les exigences appropriées soient remplies, l'expérience extérieure peut contribuer au renforcement des capacités et au développement professionnel en Afrique subsaharienne. 



\section{Introduction}

\section{The CASASE Study}

The study on quality of Curricula, Examinations, and Assessment in Sub-Saharan Secondary Education (CASASE) is one of the thematic studies in the Secondary Education in Africa (SEIA) initiative. SEIA is a multi-year (2002-2005) and a co-operation between Sub-Saharan countries, the World Bank, and other donors. SEIA consists of eight thematic studies; the CASASE study is thematic study number 5 .

Curriculum reforms are part of everyday life in education, in Sub-Saharan Africa (SSA), and elsewhere. Different strategies and methodologies have been tested, new emphases have emerged, in SSA often following the latest developments in the United States and Europe. The results of these curriculum reforms have often been fairly minimal, despite the best intentions and efforts. Identifying and critically analyzing past and present curriculum reform attempts, at both the national and international level will provide learning for future curriculum reform attempts. CASASE study analyses the quality of curricula and assessment and their development processes in Sub-Saharan Secondary Education (SE) against the background of existing contexts, conditions and ambitions on the one hand and current pedagogical thinking on the other. Taking curriculum perspectives as a basis, the CASASE objective is to provide practical and feasible recommendations for policymakers for the improvement of SE.

\section{Methodology of the Study}

The study has tried to answer the question: How can the relevance and quality of curricula, examinations, and assessment be improved at the classroom level in junior and senior secondary education in Sub-Saharan Africa? 
CASASE study reviewed and analyzed the overall situation regarding curriculum, examinations and assessment in junior and senior secondary education in selected countries in SSA. The main issues for curriculum, examination, and assessment reform have been identified and documented. The study included an extensive literature review and country visits to the four Anglophone countries of Tanzania, South Africa, Botswana, and Ghana, and francophone Senegal. The country visits have been planned and conducted in co-operation with partners in those countries.

CASASE country studies collected and analyzed data on curricula and assessment, and examined promising country-specific curriculum issues illuminative for the objective of the research. During country visits, interviews were conducted across educational levels and curriculum representations. A variety of country-specific documents were collected (policy papers, evaluation reports, international journal articles). Schools and other educational institutions were visited and relevant staff interviewed.

In addition to the data collection in-country, cross-national, international and curriculumspecific literature was analyzed. In a cross-country analysis, the findings from the individual country studies and the cross-national literature were synthesized to identify trends and patterns in the area of curriculum and assessment in secondary education in Sub-Saharan Africa. The research data also incorporates recent research experiences of the related SEIA thematic study on Science, Mathematics and ICT Education (SMICT).

At a seminar in Windhoek, first findings were discussed with experts from the countries visited and beyond. The interims draft was sent out to SSA educators for commenting. Linda Chisholm provided valuable feedback on the interims draft.

\section{Definitions}

\section{Secondary Education}

Secondary education follows the cycle of primary education, and can be divided into two phases. Different countries use different terminologies for the two phases (lower/upper secondary; O-level/A-level; enseignement moyen/enseignement secondaire; or junior secondary and senior secondary). This report uses the terms of junior secondary education (JSE) and senior secondary education (SSE) to refer to the two phases. The term secondary education (SE) encompasses both JSE and SSE.

\section{Organizational Levels of Education}

Education is organized and executed at different levels, which have different foci and influences on the curriculum:

The supra level of international policies;

The macro level of national governments and the educational system;

The meso level of educational institutes and schools;

The micro level of classes and groups; and

The nano level of individual students.

\section{Curriculum Levels}

The term curriculum is understood in its most generic form as a plan for learning. This understanding entails three major questions: what to learn, how best to learn and to teach, 
and how best to enable the teaching and learning. The curriculum is thus perceived as more than just a list of subjects and subject syllabi. It is best distinguished in the three interdependent levels of:

Intended curriculum: Consisting of the ideal curriculum reflecting the original assumptions, visions and intentions, and the formal curriculum reflecting the actual curriculum documents including textbooks, teacher guides and student materials.

- Implemented curriculum: Consisting of the perceived curriculum represented in the interpretations of its users (especially teachers); and the operational curriculum reflected in the actual instructional processes that take place in the classroom. Attained curriculum: Consisting of the experiential curriculum reflected in students' experiences, and the learned curriculum representing the learning results of students.

\section{Assessment}

The term assessment refers to all instruments applied to measure students' achievements. This includes so-called norm-referenced and criterion-referenced formal examinations, and continuous assessment practices.

\section{Relevance}

The Terms of Reference for this study explicitly refers to the relevance of curricula in the African context. In the research framework used, relevance features as the very first of the criteria used to examine the quality of curricula.

\section{Quality}

Demands for quality in education are common and frequent, but the understanding of quality is highly controversial and ambiguously applied. It is important to be clear about the distinction between the quality of instruction, and the quality of a curriculum.

The quality of instruction can be analysed by describing the interaction and interdependency of aims and objectives, content, learning activities, teacher role, materials and resources, grouping, locations, time, and assessment.

The quality of a curriculum includes the quality of instruction, but exceeds this criterion by analysing the processes and systemic context that are meant to transport the quality instruction into the classroom. Quality in curricula in this report is based on the following criteria:

Relevance of the curriculum, distinguished in relation to the subject, to the society, and to the student.

Internal and external consistency of the curriculum; the "fit" within the curriculum, and the fit between curriculum and other functions that are relevant for the curriculum, for example, assessment, professional development, and organization.

Practicality, measuring the consistency between the intended and the implemented curriculum (see curriculum levels) pointing to the feasibility of successful implementation within an existing system. 
Effectiveness, examining the consistencies between the intended and the attained curriculum.

Sustainability, analyzing the factors contributing to the short- and medium-term longevity of the curriculum.

\section{Advance Organizer}

This report in the following is organized into 10 chapters focusing on the:

Context of secondary education in SSA countries,

Formal curriculum issues and structures,

Operational curriculum (the curriculum "in action"),

Attained curriculum (about examinations and student achievement),

Curriculum development processes, and

Capacity building and professional development.

Chapter 1 introduced the CASASE study, the methodology it has used and an overview of the various definitions of relevant aspects it uses in the curriculum domain.

Chapter 2 and 3 describe the context of secondary education in Sub-Saharan African countries. Chapter 2 provides statistics for enrollment, completion and transfer rates and the like, while chapter 3 outlines the three main pillars of educational reforms (access, equity, and quality) in SSA and connects these to curriculum issues.

Chapter 4 and 5 focus on the formal (or "intended") SE curriculum in SSA. Chapter 4 looks at the way the SE curriculum is organized and reflects on the position of Technical and Vocational and Training (TVET). It focuses on important issues such as the spiral buildup of the curriculum, integration of learning and issues surrounding the language of instruction. Chapter 5 looks at the position of TVET and reflects on the TVET debate and the attempts in some countries to establish National Vocational Qualifications Frameworks (NVQFs).

Chapter 6 focuses on the implemented curriculum, the way the curriculum is put "in action." It deals with the need to modernize the teaching and learning approaches used in SSA classrooms. It contrasts the high ambitions of politicians with the realities of education in schools and classrooms and makes a case of an implementation-oriented curriculum development process.

Chapter 7 looks at examination results at JS and SS levels and reflects on the results of SSA countries in the TIMSS study. It also focuses on the important position of examinations in the curriculum implementation efforts, as well as on a number of practical issues to do with examinations and assessment.

Chapter 8 focuses on the curriculum development processes and makes an argument for a strong focus on curriculum implementation right at the early stages of the development process. It recommends the use of development research as a support activity.

Chapter 9 draws the conclusion that capacity building at all levels of the educational system is key to successful design and implementation of curriculum. This includes professional development for serving teachers, but also for relevant staff of curriculum development units and examinations agencies.

Chapter 10 focuses on a small number of conclusions and recommendations. 


\section{Context of the Sub-Saharan African Secondary Education}

\section{Enrollment in Secondary Education in Sub-Saharan Africa}

Enrollment in secondary education varies across countries in sub Saharan Africa, due to population size but also because of educational policies which is some cases restrict transition from primary to junior secondary and to senior secondary rather a lot. Tables 1, 2, and 3 provide details of the countries included in the study, for junior secondary, senior secondary, and secondary education as a whole. It also provides details on the size of the technical vocational programs in the countries.

With the success of Universal Primary Education in many SSA countries, the push for places in secondary schools has become immense. For example, in Uganda, the number of primary school leavers is increasing from 400,000 to over a million. In Tanzania, from 450,000 to 1.2 million, in Malawi it will grow from 200,000 to over 500,000 (Lewin 2004b). Even when the existing transition rates from primary to secondary are maintained (but the aim is to rather increase them), the existing schools capacities cannot absorb such large increases.

\section{Primary Completion Rates, Transfer Rates, and Gross Enrollment Ratios}

Most of the 63 million children out of an estimated 86 million children of secondary school age in SSA who are excluded from school are concentrated in four poor countries (Bregman and Simmonet 2004). In Botswana, nearly 100 percent of primary students enter junior secondary education, and 52 percent of junior secondary school leavers move on to senior secondary education; in other SSA countries (notably Tanzania and Senegal among the countries included in the sample) transition rates from primary to secondary education are a lot lower. Gross Enrollment Rates (GER) for secondary school students across Africa vary between below 20 percent and above 80 percent. Figure 1 provides an overview 
Table 1. Enrollment in Junior Secondary Education in the Five Countries in the Study

\begin{tabular}{lccc}
\hline & General programs & Tech/vocat. programs & All programs \\
\hline Senegal & 277,106 & na & 277,106 \\
Botswana & 117,574 & na & 117,574 \\
Ghana & 919,334 & na & 919,334 \\
Tanzania & 402,285 & - & - \\
South Africa* & $1,878,879$ & na & $1,878,879$ \\
Sub Sahara Africa & - & 639,395 & - \\
& & &
\end{tabular}

* 2003 figures.

Source: UNESCO 2006.

of three groups of primary completion rates, the transition rates from primary into secondary education, and the GER of the junior and secondary education cycle. Taking the Millennium Development Goal of equal access as a cornerstone for educational reform means that the inequalities significantly determine policy choices for those countries with low GER, and puts different emphasis on countries' choices of priorities for reform and spending.

With transition rates of nearly 100 percent from the primary to the junior secondary level (or the equivalent to it in South Africa), for example in Botswana 10 years and in South Africa 9 years, junior secondary education in these countries is understood as an extension of primary education to complete basic education. The transition rate in Ghana from Grade 6 to the first year in junior secondary education is 91.4 percent, but does not recognize the high dropout rates (approximately 20 percent) occurring from Grade 1 to Grade 6.

Inequities in education persist in SSA countries along lines of household incomes, location, ethnicity, and gender. Data indicates that while gender differences are diminishing (for example, Senegal JS enrollment rates are 29 percent for males, 21 percent for females; Botswana, SS: 57 percent for males and 58 percent for females), those associated with income have not. Wealth is generally a more important determinant of enrollment at secondary level than either gender or location (urban versus rural). According to Lewin (2004a), children from the richest 20 percent of households have on average more than 11 times the chance of reaching Grade 9 than those from the poorest 40 percent households.

Table 2. Enrollment in Senior Secondary Education in the Five Countries in the Study

\begin{tabular}{lccc}
\hline & General programs & Tech/vocat. programs & All programs \\
\hline Senegal & 78,626 & 4,284 & 82,910 \\
Botswana & 40,984 & 11,169 & 52,153 \\
Ghana & 338,664 & 18,672 & 357,336 \\
Tanzania & - & - & - \\
South Africa & - & - & - \\
Sub Saharan Africa & & & \\
\hline
\end{tabular}

Source: UNESCO 2006. 
Table 3. Enrollment in Secondary Education in the Five Countries in the Study

\begin{tabular}{lccc}
\hline & General programs & Tech/vocat. programs & All programs \\
\hline Senegal & 355,732 & 4,284 & 360,016 \\
Botswana & 158,558 & 11,169 & 169,727 \\
Ghana & $1,328,986$ & 18,672 & $1,350,410$ \\
Tanzania & 433,286 & $\ldots$ & $\ldots$ \\
SouthAfrica & $4,186,882$ & $\ldots$ & $4,446,841$ \\
Sub Saharan Africa & $28,722,579$ & $1,849,467$ & $30,576,317$ \\
\end{tabular}

Source: UNESCO 2006.

Rural schools are disadvantaged in terms of access and quality of education caused by, among others, difficulties to post qualified teachers to rural areas.

\section{Teachers and Student Teacher Ratios}

The number of teachers, the percentage of them trained and the student to teacher ratios vary considerable across countries in SSA. Table 4 shows details for these for four of the five countries in the study, as well as STRs for the whole of SSA, and North America and Europe. STRs in Botswana are similar to the ones in the United States and Europe. In the other countries in the sample, these are much higher.

\section{Differences Across Sub-Saharan African Countries}

The current political, economical, and developmental situations of African countries are very different. Socioeconomic factors like Gross Domestic Product (GDP) vary between countries with less than US $\$ 400$ and countries with over US $\$ 3,500$ per year, putting Botswana into the range of upper middle-income countries, South Africa and Namibia in

\section{Figure 1. Primary Completion and Transition Rates, GER Secondary Education}

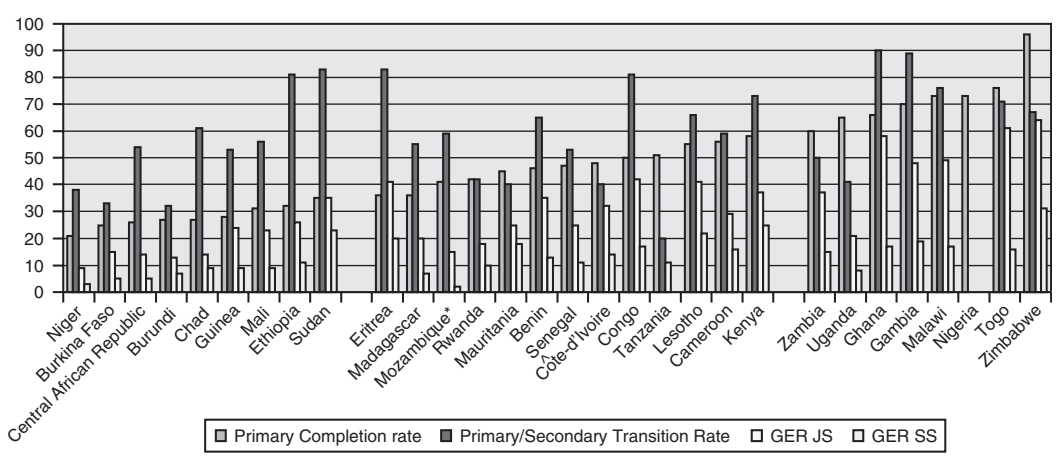

Source: Mingat 2004. 
Table 4. Teachers and Student:Teacher Ratios in Selected Sub-Saharan African Countries

\begin{tabular}{|c|c|c|c|c|c|c|c|}
\hline & \multirow[b]{2}{*}{ Total } & \multicolumn{2}{|c|}{ Teaching staff } & \multirow{2}{*}{$\begin{array}{l}\text { Trained teachers \% } \\
\text { Total secondary }\end{array}$} & \multirow{2}{*}{ Total } & \multicolumn{2}{|c|}{$\begin{array}{c}\text { Pupil:teacher } \\
\text { ratio }\end{array}$} \\
\hline & & Lower & Upper & & & Lower & Upper \\
\hline Botswana & 11,845 & 6,716 & 4,924 & 93 & 14 & 17 & 11 \\
\hline Ghana & 71,763 & 55,958 & 15,805 & - & 19 & 18 & 22 \\
\hline South Africa & 149,046 & 67,185 & 81,861 & 89 & 30 & 28 & 31 \\
\hline Senegal & 13,654 & 10.357 & 3,297 & 51 & 26 & 27 & 25 \\
\hline Tanzania & - & - & - & - & - & - & - \\
\hline Sub-Saharan Africa & $1,060,471$ & - & - & - & 29 & - & - \\
\hline East Asia (pacific) & $8,468,977$ & - & - & - & 18 & - & - \\
\hline North America/ w.e & $4,865,994$ & - & - & & 14 & - & - \\
\hline
\end{tabular}

Source: UNESCO 2006.

the range of lower middle-income countries, and the majority of SSA in the low-income category (based on a classification of the World Bank). Population numbers range form 1.6 million in Botswana, to 132 million in Nigeria, making the provision of equity in education a task of different magnitude. Annual population growths range from less than 1 percent to countries with more than 3 percent. The percentage of the population living below the international poverty line of US $\$ 2$ per day ranges from 35 percent in some countries up to 96 percent in others. African countries feature quite differently on the corruption perception list of transparency international (Transparency International 2005), for example, Botswana ranks 32nd, and the majority of African countries found in the last third and towards the low end of the list of 158 countries.

Politics in African countries have seen a multitude of varying developments influencing the current situation and peoples' lives. Ghana gained independence in 1957, Zimbabwe in 1980, South Africa held its first free election in 1994. The current levels of political stability and democratization are anything but equal. Colonial heritages have left their imprints on the educational system, with the Francophone and the Anglophone systems as the two main sources of origin. Differences in population densities and levels of urbanization between the more arid and the more tropical countries are immense. The differences extend into the countries where the educational contexts vary considerably between rural areas and urban centers, and between the poor and the wealthier.

\section{Social Perceptions of Education and Vocational Education}

Traditionally, general secondary education (SE) is regarded as a stepping-stone into socially and financially more valued white-collar jobs, or, better still, for entry into universities. With the increasing access to education and the stagnation of economies, neither tertiary education nor white-collar business can provide for the increased number of graduates leaving junior and senior secondary schools. The absorptive capacity of tertiary education is limited, 
and neither universities nor the white-collar job market can absorb present numbers of school leavers, let alone the increased numbers of secondary students in the years to come. To provide for alternative avenues in education, SSA countries intend to stream students not only into general secondary education, but into technical SSE or vocational education as well, although the latter two presently only exist in limited quantity and quality. Some countries, for example, Senegal, intend to actively limit the percentage of general SSE education, and increase technical and vocational SSE education.

To pursue goals of socioeconomic development, curriculum reforms in SSA countries aim for more and better technical and vocational education (TVET). The term TVET encompasses occupational areas ranging from agriculture to "blue collar" manual and technical trades and crafts, to "white collar" secretarial and business related careers, and the ICT related professions. Both the social reputation and the demands for blue versus white collar TVET differ considerably in SSA, with business careers and ICT professions highly sought after. The public attitude towards manual work is rather negative (Towse and others 2005). Many SE students in SSA and their families who very often bear the financial strains of education for the perspective of increased social reputation and income, presently perceive the prospective "blue collar" jobs as rather unattractive option.

Increasingly, the social perspective on secondary education shifts, particularly in urban areas. The shift is marked by perceptions that education does not make any difference for the majority of school leavers. Employment opportunities are scare, either with or without education, and for the few that find jobs it is rarely education that accounts for the difference. The success stories existing do not necessarily tell of the value of education, but of the ability to manoeuvre in rather informally structured economies and changing societies. As a result, in some areas and instances the motivation of both students and parents for education are increasingly dwindling.

In some areas, schooling is perceived of low value because of lack of teachers and resources. In a few areas, schooling conflicts with other "adult" interests, for example, early marriage of girls, or field labor. 



\section{Access, Equity, Quality, and Curriculum}

ccess, equity, and quality are the three main pillars upon which educational reform
efforts rest since the Jomtien declaration in 1990. The Dakar conference in 2002 has
highlighted that access to education does not mean access to a place for schooling
only, but equal access to quality education.

\section{Access}

Providing access to schooling is, to some extent, a fiscal and distributional question of educational and national policies, and less of curriculum reform. It overlaps with curricula where the provision of access impacts on quality, for example, rapid extension of students' enrollment and subsequent shortages of qualified teachers, and level of physical resources. The provision of equal access to schools is linked to the definition of minimum standards of physical structures. A minimum level of physical structures and resources are prerequisites for quality.

For the majority of SSA countries, increasing equity in access in secondary education is understood as to immensely expand secondary enrollment, particularly in countries with successful UPE programs. In Uganda, for example, the number of primary school leavers is increasing from 400,000 to over a million. In Tanzania, the number of primary school leavers will increase from 450,000 to 1.2 million, in Malawi it will grow from 200,000 to over 500,000 (Lewin 2004a). Even when the existing transition rates from primary to secondary are maintained (and the goals are to rather increase them), the existing schools capacities cannot absorb such large increases without increased resources. Levin (2004a) reasons that the maintenance of existing transition rates has a backwash effect on achieving 
high primary completion rates, as the dropout rates at the upper primary level will increase for students who don't see opportunities to progress further.

\section{Equity}

Equity in education depends on the revision of existing inequities in the educational systems that widely exist. Educational inequities are largely representative of inequities in society at large. While equity in education is often cited as a steppingstone to create equity in society, the question of equity in society is more dependent on other factors that cannot be influenced by education. Without changes in the society at large, existing inequities inside and outside of education are likely to be reproduced instead of eliminated. In this respect, the logic seems to be inverse: it is less the equity in education that produces equity in society, it is more equity in society that will allow for more equity in education. One should be aware that aiming at alleviation of inequities in SSA will necessitate the discussion about existing power distributions among social classes, gender, and ethnicities, and is therefore a complex and political issue. In-country disputes about equity in education and equity in society, and about the interdependency between the two often impact on educational and curriculum reform.

SE has inherited inequity. In the past, education particularly at the secondary level was provided exclusive for a minority of African children, disadvantaging those who where not enrolled. Where students were enrolled in secondary schools, they had access to different levels of quality education. These differences still persist considerably in current Africa along lines of household incomes, location, ethnicity and gender. Data indicates that whilst gender differences have been diminishing, those associated with wealth have not. Various studies, comments and observations throughout Africa show that wealth is generally a more important determinant of enrollment at secondary level than either gender or location (urban versus rural). According to Lewin (2004b), children from the richest 20 percent of households have on average more than 11 times the chance of reaching Grade 9 than those from the poorest 40 percent households. This question of access demands solutions from policies, where feasible such as by providing bursary schemes or scholarships to needy students, and/or by decreasing the relative costs of secondary education to contain private contributions within affordable limits. As well, there has not been much change in the disadvantaging differences of rural against urban areas.

The disadvantages refer to both the access to a place at school, as well as to the quality of the education provided. Providing for equal quality is strongly linked to questions of professional development, and questions of organization and management.

The question of disparity in the quality of education between rural and urban areas is largely caused by difficulties to post qualified teachers to rural areas. Solutions to this problems again calls upon policies, e.g. to provide subsidies for teachers serving in rural areas, and/or to limit the time posted in rural areas per teacher, and/or to promote teachers after a minimum time served in rural areas.

\section{Quality}

Contemporary curriculum reform in SSA refers, in one way or another, to the quality aspect of education. The need for quality in education is commonly justified from three different positions: 
To break away from the current limitations in learning of most classrooms in SSA, in terms of teaching and learning processes as well as assessment procedures.

To adapt secondary education from its traditional task to prepare for continuation into academic tertiary education, to a wider range of destinations like technical secondary education, vocational education and the world of work. As a result of increased access and increased numbers in students' enrollment, not all students can follow the common path of general secondary and subsequent tertiary education. The structural implications for the adaptation will be discussed in Chapter 5 .

To shift secondary education from academic subject learning to include more generic learning skills, in SSA mainly justified because of the need to adapt to the increase and speed of change of global knowledge, and to adapt to the changes in the political and socioeconomic context in SSA, particularly to support or boost economic development.

\section{Tensions Between Quality and Access}

The issue of quality in education overlaps with the issue of access to education where disadvantages exist less in the provision of a place at school, but in the provision of quality. Many SSA countries (such as Uganda, Senegal, and Tanzania) reply to the Education for All (EFA) development goals by focusing their policy on the quantitative aspect of education. The projections for the required number of teachers to implement the expansion and new curricula are immense (for example, SEDP in Tanzania), and for most SSA countries it seems unrealistic and hardly feasible to deliver the required output in teacher numbers (Lewin 2004a, 2004b), let alone in quality. Some countries (Senegal) employ relief-teachers that are often secondary school leavers without any pedagogical education and limited content knowledge that are widely reported to reduce the already low levels of instructional quality for years to come. The rapid expansion of educational systems suffering from lack of previously qualified teachers trades-off educational quality against access.

One further problem for the expansion of educational systems arises from the need to cater for the change in students' population. Secondary education systems that in the past have been highly selective and picked the best achievers only have to cater for a student population with mixed ability in expanded systems. Mixed ability teaching even more demands qualified and motivated teachers.

\section{Quality and Curriculum Reform}

Present learning in SSA is, for a variety of reasons to be discussed, teacher centered, oriented on the memorisation of fact, and restricted to low levels of cognitive learning. Better learning depends as a first step on the more effective and motivated use of any classroom instruction, and as a second step on the effective and motivated departure from the traditional teaching-learning approaches and methodologies to more appropriate pedagogies. The teacher is central to any improvement to occur.

Often because of the focus of the intended impact of education on economic development, the understanding of "better learning" is usually centered on the definition of 
competencies. The competencies named for contemporary curriculum reform in SSA are, at one hand, redefined from existing and commonly known learning objectives (reading, writing, numeracy), at the other hand they define learning goals that have not been spelled out before, or that are intended to be newly incorporated (learning to learn, problem solving). For the curriculum, competencies mark, amongst others, the exit skills at one educational level to progress into either the next educational level, or into the world of work. The exit skills are more or less equally defined in SSA, and fairly agreed upon. The difficulties with defining competencies begin when exit skills are translated into a conceptual and/or pedagogical framework that is less agreed upon for a number of reasons, for example, competencebased teaching approaches. It is even more difficult when these frameworks are made compulsory. Under the premises that better learning in general are only possible if the teaching-learning approaches and methodologies in classrooms change, Chapter 7 will discuss the pedagogical issues in detail. 


\section{Formal Curriculum and Curriculum Structures in Sub-Saharan Africa}

his Chapter focuses on the formal curriculum in SSA. It looks at the way the curriculum is organized, the length of educational cycles in primary and secondary education, and issues such spiral curricula, exit skills, the position in TVET in secondary education, and language of instruction. In some of the countries included in the study, curriculum content is organized in learning areas. These are highlighted for junior and senior secondary education. At both the both junior and secondary level the curriculum is extended with societal and technological requirements. These are highlighted as well.

\section{Lengths of Educational Cycles Across Sub-Saharan Africa}

The basic structures of curricula (lengths of the educational cycles. primary, junior secondary, senior secondary) vary across Sub-Saharan Africa, as depicted in Figure 2.

UNICEF considers nine years basic education as the minimum level of basic education. To prevent child labor, basic education is partly connected to the age of 15 years that in many African countries is permitted as the earliest legal entry into the labor market.

\section{Curriculum Structures in the Five Countries Visited}

Table 5 provides an overview of the curriculum structures in the countries visited for the study. In South Africa, Ghana, and Botswana; the junior secondary cycle is part of basic education, although there are considerable differences in transition rates. In Tanzania and Senegal, as in most other SSA countries (for example, Uganda and Namibia), junior secondary education is rather a separate entity in the curriculum. 
Figure 2. Lengths of Educational Cycles

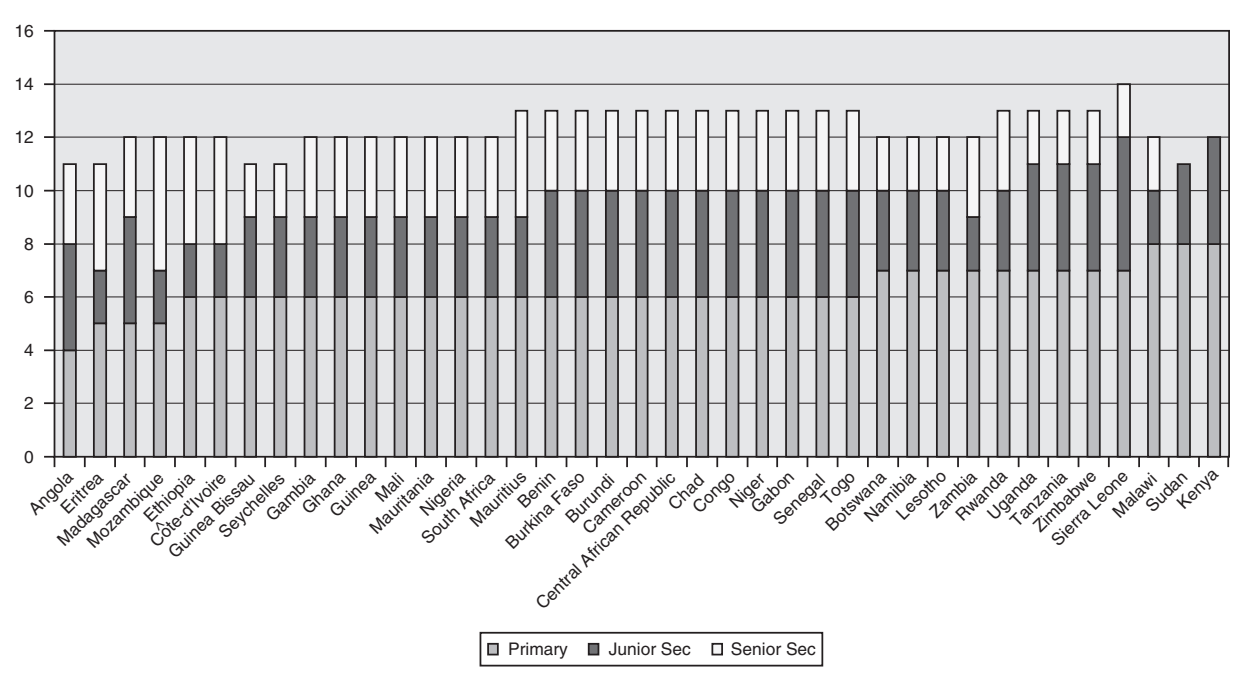

\section{Position of Technical and Vocational Education}

Traditionally, general secondary education (SE) is regarded as a stepping-stone into socially and financially more valued white-collar jobs, or, better still, for entry into universities. With the increasing access to education and the stagnation of economies, neither tertiary education nor white-collar business can provide for the increased number of graduates leaving junior and senior secondary schools. The absorptive capacity of tertiary education is limited, and neither universities nor the white-collar job market can absorb present

Table 5. Curriculum Structures in Five Sub-Saharan Countries

\begin{tabular}{|c|c|c|c|c|}
\hline \multicolumn{3}{|c|}{ Basic education and secondary education } & \multicolumn{2}{|c|}{$\begin{array}{l}\text { Primary education, junior } \\
\text { secondary education, senior } \\
\text { secondary education }\end{array}$} \\
\hline $\begin{array}{l}\text { South Africa } \\
\text { Basic education } \\
\text { (9 years): }\end{array}$ & $\begin{array}{l}\text { Botswana } \\
\text { Basic education } \\
\text { (10 years): }\end{array}$ & $\begin{array}{l}\text { Ghana (Free } \\
\text { Compulsory } \\
\text { Universal Basic } \\
\text { Education: } \\
\text { FCUBE) }\end{array}$ & $\begin{array}{l}\text { Tanzania, } \\
\text { (Uganda) }\end{array}$ & Senegal \\
\hline $\begin{array}{l}\text { Foundation (3) } \\
\text { Intermediate (3) }\end{array}$ & $\begin{array}{l}\text { Primary level: } \\
\text { lower primary (4) }\end{array}$ & $\begin{array}{l}\text { Primary } \\
\text { education (6) }\end{array}$ & $\begin{array}{l}\text { Primary } \\
\text { education (7) }\end{array}$ & $\begin{array}{l}\text { Primary } \\
\text { education (6) }\end{array}$ \\
\hline Senior phase (3) & $\begin{array}{l}\text { upper primary (3) } \\
\text { Junior secondary } \\
\text { (3) }\end{array}$ & $\begin{array}{l}\text { Junior Secondary } \\
\text { (3) }\end{array}$ & $\begin{array}{l}\text { Junior Secondary } \\
\text { (4) }\end{array}$ & $\begin{array}{l}\text { Junior Secondary } \\
\text { (4) }\end{array}$ \\
\hline $\begin{array}{l}\text { Senior secondary } \\
\text { (3) }\end{array}$ & $\begin{array}{l}\text { Senior secondary } \\
\text { (2) }\end{array}$ & $\begin{array}{l}\text { Senior secondary } \\
\text { (3) (to become 4) }\end{array}$ & $\begin{array}{l}\text { Senior secondary } \\
\text { (2) }\end{array}$ & $\begin{array}{l}\text { Senior secondary } \\
\text { (2) }\end{array}$ \\
\hline
\end{tabular}


numbers of school leavers, let alone the increased numbers of secondary students in the years to come. To provide for alternative avenues in education, SSA countries intend to stream students not only into general secondary education, but also into technical SSE or vocational education although these two presently only exist in limited way. Some countries, e.g. Senegal, intend to actively limit the percentage of general SSE education, and increase technical and vocational SSE education.

To pursue goals of socioeconomic development, curriculum reforms in SSA countries aim for more and better technical and vocational education (TVET). The term TVET encompasses occupational areas ranging from agriculture to "blue collar" manual and technical trades and crafts, to "white collar" secretarial and business related careers, and the ICT related professions. Both the social reputation and the demands for blue versus white collar TVET differ considerably in SSA, with business careers and highly sought-after ICT professions. The public attitude towards manual work is rather negative (Towse and others 2005). Many SE students in SSA and their families who very often bear the financial strains of education for the perspective of increased social reputation and income, presently perceive the prospective "blue collar" jobs as rather unattractive option.

Increasingly, the social perspective on secondary education shifts, particularly in urban areas. The shift is marked by perceptions that education does not make any difference for the majority of school leavers. Employment opportunities are scare, either with or without education, and for the few that find jobs it is rarely education that accounts for the difference. The success stories existing do not necessarily tell of the value of education, but of the ability to maneuver in rather informally structured economies and changing societies. In some areas in some countries, schooling is perceived of low value because of lack of teachers and resources. In a few areas across SSA, schooling conflicts with other "adult" interests (for example, early marriage of girls, or the use of children for field labor).

Although limited to some areas and instances, the overall observation indicates that the motivation of both students and parents for education are dwindling. A T-Shirt imprint seen in Dakar, Senegal exaggerates but may symbolize this trend: "If it weren't for the girls, I'd quit school."

\section{Exit Skills}

Exit skills mark the minimum learning outcomes that are required to proceed from one educational level to the options given at the next level. The definitions of exit skills at the various exit points are critical for the curriculum. Without clearly defined exit skills, learning at the next level is severely limited.

The respective educational minimum targets (either UPE or basic education) determine the length of the first educational cycle, and mark the first terminal exit point for exit into the world of work. The first terminal exit point usually marks the departure gate for continuation into further academic education, further vocational education, or the world of work (including various forms of self-employment). Depending on the curriculum structures, the exit points into the world of work in SSA can vary considerably. Figure 3 shows the different exit points into the world of work as are either theoretically or realistically given in the various SSA countries. 


\section{Figure 3. Different Exit Points into the World of Work}

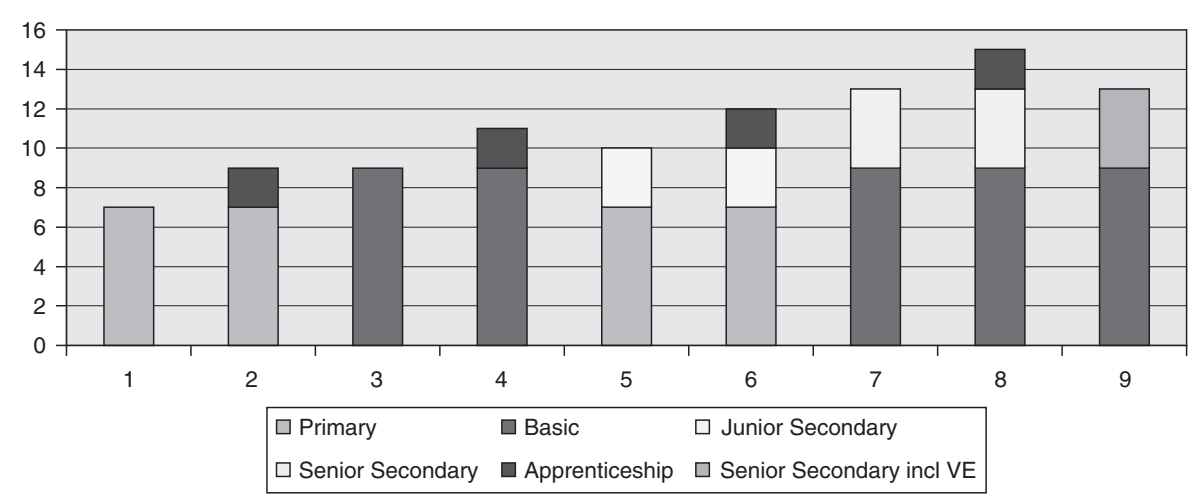

The provision of either UPE or basic education determines the length of the first educational cycle and the first terminal exit point. Table 6 summarizes exit points, intended exit destination, and the minimum level of competencies as extracted from present and recent SSA curriculum reforms. Because of socioeconomic realities, the continuation into the world of work is a theoretical option only for most students.

Most SSA countries detail the "new" competencies (learning to learn) into further subcompetencies. In all of the five SSA countries visited, the need for additional competencies

Table 6. Exit Points, Continuation, and Exit Skills

\begin{tabular}{|c|c|c|c|}
\hline & When? & Continuation into & Exit skills (competencies) \\
\hline $\begin{array}{l}\text { Exit } \\
\text { point } 1\end{array}$ & $\begin{array}{l}\text { After primary } \\
\text { education }\end{array}$ & $\begin{array}{l}\text { World of work (unskilled } \\
\text { labor) and society. } \\
\text { Junior secondary education. }\end{array}$ & $\begin{array}{l}\text { Reading and writing. } \\
\text { Basic numeracy. } \\
\text { Language proficiency in the } \\
\text { instructional language for } \\
\text { continuation into JSE } \\
\text { Basic problem solving. }\end{array}$ \\
\hline $\begin{array}{l}\text { Exit } \\
\text { point } 2\end{array}$ & $\begin{array}{l}\text { After junior } \\
\text { secondary (in } \\
\text { countries with } 9 \\
\text { or } 10 \text { years of } \\
\text { basic education, } \\
\text { this is the first } \\
\text { exit point) }\end{array}$ & $\begin{array}{l}\text { Secondary education, } \\
\text { general streams } \\
\text { Secondary education, } \\
\text { technical streams. } \\
\text { Vocational education. } \\
\text { World of work (low-skilled } \\
\text { labor) and society. }\end{array}$ & $\begin{array}{l}\text { Self and social } \\
\text { responsibilities. } \\
\text { Basics of learning to learn. } \\
\text { Problem solving. } \\
\text { English (French). } \\
\text { Mathematics (including } \\
\text { Geometry). } \\
\text { Academic knowledge for } \\
\text { continuation into general } \\
\text { secondary education. }\end{array}$ \\
\hline $\begin{array}{l}\text { Exit } \\
\text { point } 3\end{array}$ & $\begin{array}{l}\text { After senior } \\
\text { secondary } \\
\text { education }\end{array}$ & $\begin{array}{l}\text { General tertiary education. } \\
\text { Technical tertiary education } \\
\text { (polytechnics). } \\
\text { World of work and society. }\end{array}$ & $\begin{array}{l}\text { Advanced learning to learn. } \\
\text { Problem solving. } \\
\text { Specific subject and } \\
\text { discipline knowledge. }\end{array}$ \\
\hline
\end{tabular}


to respond to the increasing changes in values and culture of SSA societies are stated, for example, by adding competencies of cultural knowledge and civic education to the list. Most countries include HIV and AIDS awareness in the list of competencies. Some countries, such as Senegal, see HIV awareness as an important area of concern to be addressed in society at large, and therefore do not incorporate it into their curriculum.

\section{Issues in Secondary Education Curriculum}

\section{Spiral Buildup of Curricula: Knowledge within Subjects}

The groundwork for successful secondary education lies at the primary levels. Independently of whether junior secondary education forms part of basic education or not, teaching opportunities and learning potential at the junior secondary level depend strongly on the exit skills at the end of the primary level, particularly elementary skills like reading, writing, and basic mathematics. Shortcomings at the primary level are inevitably extended into junior secondary education. A report on the monitoring of learning achievements in Botswana (Republic of Botswana 2001) has confirmed common observations: primary students' achievements in numeracy and the second language (English) are particularly weak, and the weaknesses correlate with weaknesses in the same subjects at the junior secondary level. Solving the language proficiency and numeracy problem at the secondary level needs to start by tackling the problems at primary education. Weaknesses in the second language to become the instructional language at the secondary level are of particular concern. Second language proficiency is a pre-requisite for both continuation into further education, and increasingly for successful communication and participation in society. The current organization of SSA curricula expects primary school leavers to be proficient in the instructional language at the SSE level (English, French).

Research has shown that the formal curricula in SSA have improvement potential. It has repeatedly been observed that the intended spiral build-up within a subject often revolves around repetition of the same subject content with similar degrees of difficulty across educational levels.

In many areas of subjects or learning areas of one educational level, further learning depends upon achievements of knowledge or methodological skills attained at prior educational levels (vertical consistency). Particularly where the depths and standards of concept learning in a subject increase in the course of schooling, the learning potential at the higher level depends on learning achievements at lower levels. The formal curriculum can contribute to vertical consistency by designing graded learning outcomes and subject matter spirally built-up across educational levels. Curriculum design needs to cater for sequencing, progression and the pace of learning matter. It needs to be acknowledged that different subjects or learning areas have different design requirements and different "fits" with modern teaching-learning approaches. It deserves attention that even with a learningcentered or learner-centered approach, content knowledge still matters. For some subjects in some countries, such as geometry in Senegal, the time gap between related subject content of two levels is too long to allow for connectivity of prior to new learning.

The progress from one knowledge and skills level to the next one, either within a subject or from grade to grade, benefits from clear definitions of the required transition knowledge and skills in both curriculum and assessment. The learning programs and 
assessment practices at the various education levels must ensure that the prescribed exit skills are covered effectively and comprehensively. In general, exit skills need to be clearly defined. They are needed to "design down" the curriculum from the higher to the lower levels. Both the design of subject matter across educational levels, and the definition of clear exit skills require co-operation and communication amongst curriculum designer of one subject, and/or assessment.

Over the years, societal developments have led to the tendency to include a variety of new topics into the curriculum, or at least into parts of the curriculum, for both JSE and SSE. The general tendency to add these topics without replacing and omitting less relevant ones have led to widespread complaints that subject curricula have become overloaded, thereby exchanging quantity of learning matter against potential quality in learning.

\section{Integration of Learning}

On a horizontal level, a curriculum can promote the integration of learning of both content and skills across subjects or learning areas by combining related learning matter within a grade. A coordinated approach to more appropriate methodologies and assessment methods, such as portfolios or project work, will enhance the students understanding and versatility with it. However, this relevant ideal for classroom and school practice depends less on a formal curriculum, but more on a well-developed professional school culture.

In an interest to integrate learning by formal curriculum restructuring, for some subjects or learning areas it has been observed that the formal reorganization of content matter is prone to create an overlap of similar if not the same learning matter across subjects that doubles up teaching and efforts, and wastes teaching time. For example, in some countries it was reported that the high emphasis to create awareness about HIV and AIDS has resulted in repetition and an over-teaching of the same facts again and again.

\section{Literacy and Language of Instruction}

Literacy, particularly reading and writing, is an important skill for participation in society in general. Literacy and language proficiency in the instructional language are of utmost importance for entry into junior secondary education, and a prerequisite for learning of most subjects and for many skills. Students need to be able to read fluently across a range of texts and to reflect critically on what is read, and to write fluently for a range of purposes and audiences. The need and complexity for language proficiency and literacy skills increases for exit skills at the senior secondary level, particularly for students continuing into tertiary education.

For most students in the majority of SSA countries the language of instruction and the language of most examinations at the secondary level is not the mother tongue of the student. The linguistic classroom reality, particularly at the junior secondary level, seems for the majority of students to be more of an obstacle than a medium for instruction and examination. Particularly for the sciences and mathematics there is a positive correlation between language proficiency and understanding (Howie 2002). In SSA countries, the majority of students struggle to learn academic content because of the foreign medium. In South Africa, the language proficiency of second language learners at the lower range of the secondary level did not even compare with Scottish students at the foundation level, and 
is identified as a major contributor to poor learning and poor performances (Umalusi 2005). Where students diverge in their command of the instructional language, examinations may measure language competency rather than mastery of understanding.

Brock-Utne and Hollmarsdottir (2004) argue for both Tanzania and South Africa that in the classroom teachers' use whatever language they and their students are comfortable with. Particularly if students appear not to understand the teacher in the instructional language, the teacher performs what is known as code-switching (switch in language between sentences) and code-mixing (switch within the same sentence), and translations. However, at the end of the day students have to decipher and write examinations in English (respectively French in Francophone countries).

Prophet (1995) indicates that mother tongue instruction benefits the understanding of scientific cognitive concepts as compared to instruction in a second language (in this case English), in which students are not sufficiently fluent. In some countries, switching to the use of vernaculars as languages of instruction in SSA secondary classrooms is currently controversially debated, partly because of its political connotations. Languages are bearers of cultures. Vernacular instruction bears the danger to open a gap of the door to tribalism, particularly if the vernacular is not the mother tongue of the student. Instruction in vernacular languages has, it has been argued, promoted ethnic difference and conflicts, especially when the indigenous language on offer is not that of the student. One major argument against promoting the indigenous language over another in context of many languages is the promotion of ethnic rivalry and conflict.

Another argument against the use of mother tongue instruction for all students is that it is difficult to achieve practically, particularly if there are more than one mother tongue in a classroom as often pertains in Ghana and South Africa, and if the mother tongues of students and the teacher differ. In some regions of SSA countries, there may also be differences between dialects, and problems around the choice of the dialect. Concerning instructional material, further practical challenges arise in countries with a multitude of mother tongues. Some African languages have no written framework, such as in some parts of Ghana. Second African language speaking students may be further disadvantaged by the syllabi of the African language, which may not promote higher cognitive learning (Umalusi 2005; such as South Africa).

South Africa initially embraced a very ambitious language policy ( 11 official languages plus sign language), and a comprehensive language development plan that intended to use whatever language for all ways of life including education. However, this policy seems in practice to have had to step back from its high ideals because of lack of practical and feasible solutions for the classroom.

Increasingly, bilingualism is considered a reality in many parts of the world, and termed as the norm in SSA. Research results suggest that bilingual schooling offers benefits for learning. The UNESCO report (2005), citing a reference to Benson (2004), claims that "in the most successful models, the mother tongue is used in the early years of schooling so that children can acquire and develop the literacy skills that enable fuller participation in learning activities." Educational bilingualism is based on the principle to maintain home language while providing access to and the effective acquisition of an additional language. which. According to the same report, the research findings are said to be encouraging for the aims of societal and individual multilingualism.

A cross-national study of twelve Anglophone SSA countries (Human Sciences Research Council 2006) established that all language policies aim to eventually establish 
English as the method of instruction (MOI) at the primary level. However, there is variation in terms of when the transition from mother tongue to English is made, and consequently the level at which English is first introduced. In eight of the countries the MOI in the first three years is the local language of the learners, or a specified indigenous language. In this way initial reading and writing skills are acquired, and the acquisition of the second language to become the medium of instruction for the rest of the school years will be facilitated more easily. English is taught as a second language, and in the fourth year of primary school, the transition to English as the MOI is made. In six of the twelve countries the secondary language curriculum is structured around four main language skills: listening, speaking, reading, and writing. There seems to be general agreement that the teaching of a local and English at the primary level should focus on reading, writing, dictation and comprehension to equip students with the required exit skills of basic literacy.

Senegal, a Francophone country, presently pilots a comparable language policy for 6 out of 12 languages, where mother tongue instruction is used for the first three years for learning reading, writing and maths, before the switch is made to French as the instructional language at the secondary level.

The idea behind the policy of bilingualism is that primary students learn a new language rapidly if instructed properly. This way out of the language problem in SSA acknowledges both the cultural as well as the cognitive aspect of mother tongue instruction. It has two major implications for the curriculum: first, the syllabi for the first language should be developed with the development of higher cognitive learning in mind; and secondly and particularly for the Anglophone countries, more language and other subject teachers are required who are more proficient in the second language themselves, particularly at the primary level.

Other curriculum interventions in SSA aim at tackling the problem of language proficiency at the beginning of the JSE level. For example, some schools in Tanzania voluntarily provide for additional remedial English language classes or courses at the beginning of secondary schooling. The Botswana secondary curriculum notes that the focus on SE English will be on the use of second language methodologies and pedagogical approaches while still maintaining high standards for the subject.

\section{Junior Secondary Education as Part of Basic Education}

Table 7 shows the objectives and structure of the junior secondary education cycle as located between the extension of primary education, and the continuation into senior secondary education or the world of work. The excerpts of the three curricula in Botswana, Ghana, and South Africa show different aspects of junior secondary education as a continuation of primary education (objectives, aims, structure). It is worth noting that the primary curricula at the first level concentrate on foundational literacy (reading, writing, comprehension), and on numeracy.

\section{Subjects and Learning Areas in Junior Secondary Education}

Considering that junior secondary education is an exit point into both the world of work and further secondary education, the challenges for junior secondary education are to equip students to prepare for the triple requirements of the world of work, society, and senior secondary education. There is general agreement that the learning matter at the 
Table 7. Three Examples of Basic Education Curricula in Sub-Saharan Africa

\begin{tabular}{|c|c|c|}
\hline Botswana & Ghana FCUBE & South Africa \\
\hline $\begin{array}{l}\text { Lower primary level (4 years): } \\
\text { broad subject packaging, some } \\
\text { subjects integrated to facilitate } \\
\text { theme and project teaching; } \\
\text { learner-centered approach }\end{array}$ & \multirow{2}{*}{$\begin{array}{l}\text { Primary education (6 years): } \\
\text { Reduction of too many subjects } \\
\text { is the key-word. Basic literacy } \\
\text { with focus at the early stage on } \\
\text { reading, writing, dictation and } \\
\text { comprehension of texts in both } \\
\text { Ghanaian language and English. } \\
\text { Numeracy as the second major } \\
\text { focal point, and social science as } \\
\text { the third. }\end{array}$} & \multirow[t]{2}{*}{$\begin{array}{l}\text { Foundation phase } \\
\text { (3 years): } \\
\text { Literacy } 40 \% \\
\text { Numeracy } 35 \% \\
\text { Life skills } 25 \%\end{array}$} \\
\hline $\begin{array}{l}\text { Upper primary ( } 3 \text { years): } \\
\text { mainly development of } \\
\text { pre-requisite skills for junior } \\
\text { secondary curriculum. }\end{array}$ & & \\
\hline $\begin{array}{l}\text { Junior secondary (three years): } \\
\text { acquisition of foundation skills } \\
\text { such as decision making, } \\
\text { problem solving, team work, } \\
\text { computing, vocational } \\
\text { orientation of academic } \\
\text { subjects, knowledge and } \\
\text { processes and the appreciation } \\
\text { of technology; familiarity with } \\
\text { tools and materials. Cross- } \\
\text { curricular issues infused. }\end{array}$ & $\begin{array}{l}\text { General curriculum preparing } \\
\text { for entry into Senior Secondary } \\
\text { (Senior Secondary specialized in } \\
\text { one of the following: Grammar, } \\
\text { Technical, Vocational, and } \\
\text { Agricultural courses). }\end{array}$ & $\begin{array}{l}\text { Intermediate and senior } \\
\text { phase (junior secondary) } \\
\text { of basic education cycle } \\
\text { ( } 3+3 \text { years): } \\
\text { Languages } 25 \% \\
\text { Mathematics } 18 \% \\
\text { Natural Sciences } 13 \% \\
\text { Social Sciences } 12 \% \\
\text { Technology } 8 \% \\
\text { Economic and manage } \\
\text { ment sciences } 8 \% \\
\text { Life orientation } 8 \% \\
\text { Arts and culture } 8 \%\end{array}$ \\
\hline
\end{tabular}

junior secondary education should move to be more deeply structured than broad-based, and aiming at the transmission of generic knowledge structures, skills, and methodologies.

Although most SSA countries accept schools with exceptional subject combinations that are either given by the availability of teachers, or by traditional school profiles, current educational reforms in all of the countries visited promote the reduction of subjects from formerly overloaded curricula with sometimes extensive subject options. Reducing the overload allows for an adjustment to more modern pedagogies, enable a more focussed, cost-effective and manageable structure of the curriculum, and allow for valuable extracurricular activities that have a high potential for personal development and the maintenance of cultural and social cohesion (Republic of Ghana 2002; O-saki 2001).

Table 8 provides an overview of the curriculum structures (subjects and learning areas) of the junior secondary level in five SSA countries. For comparison, the subjects and learning areas are grouped in related categories. Time allocations are in brackets.

In most SSA countries, issues of health education, particularly HIV prevention, and increasingly drug prevention, are mainly infused into other subjects. Senegal has taken HIV/AIDS out of the curriculum and has made it part of a nationwide awareness program.

The average percentage of time allocated for Mathematics at the junior secondary level (year 8 and 9 of formal schooling) across SSA is with 17.2 percent above the international average of 13.2 percent. On an international level, environmental education and technologyrelated education have received the most notable increases in time allocations in recent years. The time allotted to subjects related to moral values has increased over the last two decades 


\section{Table 8. Subjects and Learning Areas, Junior Secondary in Five Sub-Saharan Countries}

\begin{tabular}{|c|c|c|c|c|}
\hline $\begin{array}{l}\text { Tanzania SEDP curriculum } \\
\text { Junior Secondary level } \\
\text { core subjects }\end{array}$ & $\begin{array}{l}\text { Ghana Junior Secondary } \\
\text { curriculum }\end{array}$ & $\begin{array}{l}\text { Botswana Junior Secondary } \\
\text { curriculum core subjects }\end{array}$ & $\begin{array}{l}\text { South Africa C2005 learning } \\
\text { areas of the revised } \\
\text { curriculum JSE level }\end{array}$ & $\begin{array}{l}\text { Senegal (curriculum of } \\
\text { 1980, final year JSE, based } \\
\text { on } 28 \text { periods/week) }\end{array}$ \\
\hline Kiswahili & $\begin{array}{l}\text { Ghanaian language and } \\
\text { culture }(10 \%)\end{array}$ & Setswana (10\%) & Languages (25\%) & French (21\%) \\
\hline English & English language (15\%) & English (12.5\%) & & $\begin{array}{l}\text { Living language 1: English } \\
\text { or German (14\%) }\end{array}$ \\
\hline Mathematics & Mathematics (15\%) & Mathematics (12.5\%) & Mathematics (18\%) & Mathematics (18\%) \\
\hline Biology & Integrated Science (10\%) & Integrated Science (12.5\%) & Natural Sciences (13\%) & Earth and Life Science (7\%) \\
\hline Physics with Chemistry & & & & Physics or Technology (7\%) \\
\hline \multirow[t]{9}{*}{ Civics } & Social Studies (7.5\%) & Social Studies (10\%) & $\begin{array}{l}\text { Social Sciences (12\%); now } \\
\text { two subjects of history and } \\
\text { geography }\end{array}$ & $\begin{array}{l}\text { Civic education (3.5\%) } \\
\text { History and Geography (7\%) }\end{array}$ \\
\hline & Pre-technical skills (7.5\%) & $\begin{array}{l}\text { Design and Technology } \\
(10 \%)\end{array}$ & Technology (8\%) & \\
\hline & Agricultural Science (7.5\%) & Agriculture (10\%) & & \\
\hline & & & $\begin{array}{l}\text { Economics and } \\
\text { Management (8\%) }\end{array}$ & \\
\hline & $\begin{array}{l}\text { Religious and Moral } \\
\text { education (7.5\%) }\end{array}$ & Moral education (5\%) & Life Orientation (8\%) & \\
\hline & & & Arts and Culture (8\%) & Music or Arts (3.5\%) \\
\hline & Pre-vocational skills (7.5\%) & & & \\
\hline & Life skills (5\%) & & & \\
\hline & & & & Physical education (7\%) \\
\hline Plus: options where offered & $\begin{array}{l}\text { Plus: French }(7.5 \%) \text {, where } \\
\text { teachers available; Music } \\
\text { and Dance; Physical } \\
\text { Education for morning } \\
\text { shift schools }\end{array}$ & $\begin{array}{l}\text { Plus: options of practical } \\
\text { studies, plus options of gen- } \\
\text { eral studies }\end{array}$ & & $\begin{array}{l}\text { Plus: options where teacher } \\
\text { available: Living language } 2 \\
\text { (e.g. Arabic, German, } \\
\text { Spanish); } \\
\text { Home economics }\end{array}$ \\
\hline
\end{tabular}


in SSA (World Bank 2005). It is important to note that the time allocations only indicate the learning potential awarded to a subject, but nothing about the learning outcomes.

South Africa has organized its C2005 (Grades 7 to 9) in eight learning areas instead of subjects. Over the last two decades, other curriculum reforms in SSA aim at a limitation of subjects for the junior secondary curriculum to the number of eight. The integration of subjects, such as in science, follows an international trend, not without problems even in developed countries. Theoretically, integrated science (and other learning areas) allows for a more contextualized and holistic learning approach by combining elements of related subject areas (for example, biology and chemistry), and allows focusing on integrated learning and the teaching of competencies instead of content subject matter.

Tanzania, for example, combines physics and chemistry into one subject. The combination is commonly perceived as formal only. In practice, schools will teach the subjects with two teachers, and divide the time allocated between the two subjects. In Ghana offering integrated science at both the junior and the senior secondary level, the subject is mainly divided into its components (Chemistry, Physics, Biology, Agricultural Science), and taught by more than one teacher.

While this holistic approach and the combination of subjects into learning areas are consistent with modern educational philosophies, it has created numerous practical problems, or likely will meet the following problems:

Teachers expected to teach the learning areas lack the required combined knowledge of related subject contents to teach the learning areas in a meaningful way since they have neither themselves been educated like this, nor in the majority of cases have been trained accordingly (although Ghana provides for integrated science studies at the teacher education level).

The instructional materials (especially textbooks) for both learning areas and the new pedagogical approaches are lacking.

Teachers already struggle with new teaching approaches in subjects in which they are comfortable and knowledgeable.

Where learning areas or integrated subjects have been introduced in the junior secondary curriculum (Namibia, South Africa), students are reported to dramatically lack the basic content knowledge for continuation at the senior secondary level where education follows the traditional subject divisions.

\section{Curriculum Extensions at Both Junior and Secondary Level}

\section{Life Skills}

In the majority of SSA countries, the end of primary or basic education will be a terminal point for many students. For those students who cannot find continuation into TVET or general education, African countries feel the need to provide for so-called life skills as part of the upper grades in primary or basic education (for example, Ghana, and Tanzania Grades 4 to 7; in Tanzania recommended by Mosha Task Force, 1993). The definition of the term life skills varies across African countries and educational levels. In the context mentioned before life skills are meant as skills allowing a low-scale participation within the 
economy in the immediate environment of the student. The subject life skills in Tanzania includes skills such as needlework, tailoring, simple metalworking, or domestic wiring; in Ghana life skills is understood as pre-vocational options of local crafts like basketry, leatherwork, weaving, pottery, textiles, and sculpture, to name a few.

The teaching of these life-skills is located at the primary education level aiming at primary school leavers. For this report, focusing on formal secondary education, it is of no further relevance.

Note: The learning area Life Skills in Namibia at the JSE level has a different conceptual background, and cannot be compared to the subject before.

\section{Guidance and Counselling, Citizenship}

Young people in SSA today continue to face new challenges and realities such as limited opportunities for further training and employment. The internationalisation of culture influences children in SSA stronger than adults. The traditional setup of the extended African family networks change, and traditional social services and support systems continue to fragment. Formerly unknown social problems arise. SSA societies, like many others in the world, are becoming more and more complex. Some SSA countries (strongly Botswana, but also Senegal) increasingly feel the need to introduce more and effective guidance and counselling and/or citizenship as part of the secondary curriculum to positively influence societal developments, or to counter the vacuum created by the disintegration of traditional structures. Schools are expected to provide services and activities focusing on the educational, social, and personal and career concerns of their studentsfor the latter, assisting students in career orientation, subject and examination choices, and handling of wider ability groups. One needs to acknowledge that the socio-correctional potential of the curriculum is limited, and that positive changes are rather dependent on policies and societies at large, such as creation of employment.

\section{ICT}

Particularly Botswana and Ghana emphasize the need to include computing skills into the curriculum to by providing computer science courses at the junior level. Other African countries similarly attempt to make efforts to include ICT into their curricula, although mainly at the senior secondary level.

Regarding ICT it is worth distinguishing between the two different conceptual starting points of:

ICT as an object or subject of study with the rationale to prepare students for jobs and for the technically advanced society to come (so-called computer literacy). The use of the word "literacy" in this context implies a high-ranking educational aim, comparable to language literacy. It also implies the transfer or building of high-ranking intellectual capacity. These implications may lead to faulty conclusions. Computer literacy usually refers to usually technical mastery of computer skills (keyboard skills) and applications such as Office software. However, basic knowledge about the use of computers and software should be regarded as part of modern education, and most of the ten countries surveyed for the SEIA study on Science, Mathematics 
and ICT education (Ottevanger, van den Akker, de Feiter 2004) have introduced ICT as a separate subject with its own assessment. As an alternative, computer knowledge may theoretically be infused into the curriculum as a cross-curricular issue (as is the case in the JS curriculum in Botswana), but this is much more difficult to implement.

ICT proves to be a powerful tool when trying to shift teaching and learning to more active forms. It will alter teachers' roles to a facilitator in the teaching and learning process. The biggest challenge in this area is to update teachers' skills using ICT as pedagogical tools for learning. The current important focus in SSA on ICT infrastructure has perhaps made that sight has somehow been lost on this important aspect of ICT use in teaching and learning. Some of the applications in teaching and learning may require specific skills (simulations, animations, micro-based laboratories) as well as additional facilities such as sensors and interfaces for measuring.

The use of ICT in education requires considerable resources, for equipment, maintenance, and internet access. In many African countries donors relatively easily sponsor the generation and installation of computers in schools. The subsequent maintenance of computers and of the related infrastructure has developed into substantial challenges for schools and educational systems in SSA. ICT laboratories with many more broken down computers than actually functioning ones are common sights across SSA. Educational developments in SSA that in one way or another bank on ICT (in in-service, for support structures, or for knowledge dissemination) have proven to stall or encounter difficulties because of regular maintenance problems, breakdowns, or because of lack of infrastructure (such as telephone lines). The SchoolNet movement in Africa provides support to schools in their implementation of ICT facilities in schools. Especially SchoolNet Namibia has been exemplary in setting up structures for school networks using refurbished computers and server and using Open Source software. It has also set up structures in areas in Namibia without telephone lines and mains electricity.

\section{Education with Production, and Agriculture}

Education with Production (EwP) originated in community-based vocational education in Botswana in the 1960s. Based on the philosophy of self-reliance, some countries (Zimbabwe and former SWAPO schools in Zambia) transferred the idea of Education with Production $(\mathrm{EwP})$ from vocational education into general secondary education. In Namibia, a diluted version of EwP was supposed to be part of the subject "Life Science" at the junior secondary level. Due to the loss of the initial appeal of the idea of self-reliance, and the changed expectations at secondary education, EwP has found a natural death at the secondary schooling level, and seems to be terminated soon as the brigades' model of vocational education in Botswana, where it will be exchanged with another program (BTEP).

However, the somehow related area of agriculture deserves special interest. Apart from the fact that most African cultures are based on "tang of the soil" (Ki-Zerbo 1977), the majority of current African economies rely on it. In Tanzania the agricultural sector employs 80 percent of the work force, accounts for 85 percent of exports, and provides 48 percent of the GDP (Ottevanger, van den Akker, and de Feiter 2004). In Ghana, agriculture accounted for 37.6 percent of the GDP in 1998 (although down from 56.2 percent in 1977), and the 
traditional sector of agricultural and informal activities employs over 80 percent of the labor force (Towse and others 2005). In spite of the importance of agriculture for the economy and the society, Tanzania has dropped agriculture from the secondary curriculum in preparations to provide for the modern society to come. In contrast, in Ghana agricultural science is still part of the junior secondary curriculum and an option for continuation at senior secondary level.

\section{General Senior Secondary Education Curriculum Structure}

The context and objectives of the senior secondary education sector (SSE) in SSA are bound to change. Most SSA countries intend to stream JSE graduates not only into general and rather academic secondary education, but as well into technical SSE or vocational education. The conceptual starting point for SSE is whether it is designed to prepare students for both tertiary and non-academic education (technical, vocational), or if technical and vocational education runs parallel to general SSE. In the latter case, general SE caters mainly for continuation into tertiary education. The questions about integration and demarcation of education, of technical and vocational education (TVET), and the structural options and implications will be discussed in Chapter 5 .

Independently of the designation for SSE, it is wedged in between comprehensive junior secondary education with its new exit profile, and, at least in some countries, the academic necessities to continue to tertiary education. Where JSE in SSA has intended to include ideas of LCE and/or has expanded its access and/or has shifted to learning areas, senior secondary teachers frequently complain about lack of skills and knowledge of junior secondary leavers on an even higher level as already existed before. The reported lack of skills and knowledge ranges from lack of basic reading, writing, and basic mathematical skills, to the lack of foundational and pre-requisite subject content knowledge. This lack of pre-requisite knowledge is particularly grave in all subjects where knowledge and skills are spirally built-up, and where a meaningful continuation at the SSE level depends on a foundation of prior knowledge. Secondary education is challenged with the provision of a minimum of exit knowledge and exit skills to allow for quality tertiary education. Yet, similar complaints about the lack of basic skills are reported from the tertiary level as well.

Across SSA, SSE curricula show a great variety of organization and subject structures. They have in common some that they provide for some kind of specialization that are expected to treat selected content and objectives in greater depth and breadth. Two basic SSE curriculum structures dominate in SSA, each subscribing to a different understanding of exit skills at the end of the secondary level. The first and wider-spread structure prescribes Language (either the local and the instructional language, or the instructional language only, for example, Ghana and Senegal) and Mathematics as compulsory core subjects, or as part of a wider range of compulsory core subjects, with additional elective subjects optional for students to choose.

The second structure, for example in Tanzania, offers specialized and highly selective combinations of core courses of usually three subjects, which schools may define, and which define the school.

The Senegalese SSE curriculum can be located in between the two structures. It offers different streams in either areas of languages, sciences, technical education, or commerce 
that consists of core subjects, but with different emphasis and time allocations; plus additional compulsory subjects for each stream, e.g. philosophy for the languages.

In many countries where subjects or subject combinations are offered, schools are eager to offer as many combinations as possible. Students are reported to be more motivated to learn in chosen subjects. In theory, students may choose the combination based on their preferences. In reality it appears as if some combinations are highly sought after (for example, science combinations, or business studies), and students will be streamed into subject combinations according to their junior secondary examination results. In Ghana, schools in most cases modify the choice of subjects because of lack of teachers or to satisfy university entry requirements (Ampiah, Akyeampong, and Leliveld 2002). For private schools, the financial capacity of parents may be of advantage for the selection possibilities of students with poorer examination results. Table 9 provides an overview of the variety of senior secondary curriculum in five SSA countries.

\section{Vocationalized Education}

Increasing the economic relevance of education, and linking education and particularly secondary education to the world of work is a major concern in SSA countries. The challenges for this are two-pronged: it is firstly the structural challenge to systemically interlink secondary and vocational, and it is secondly the actual provision and quality of both vocational (TVET) and vocationalized education. The term "vocationalized" education is not to be understood as vocational education. Vocationalized education is part of the curriculum of general schools. At the secondary education level it aims to prepare students for the world of work in the sense of development of attitudes, skills and knowledge relevant to the adult society. It does not mean specific vocational courses as an entry into a particular trade or occupation. The main distinctions between vocationalized education and TVET are:

Vocationalized education refers to a curriculum mainly "academic" in nature, but which includes vocational or practical portions in the timetables during either junior and/or secondary cycle (as in partly the Senegalese curriculum). Vocational education is part of general education, and does not imply that students have left the path to tertiary education.

Technical and vocational education and training (TVET) is usually designed for occupations, clusters of occupations, or the world of work. TVET can be either school-based or apprenticeship based, and the courses are dominated by practical skills learning directly related to theory. The continuation into tertiary education is limited, and where existing, usually restricted to technical subjects at universities.

In present SSA, the linking of education to vocation shows a variety of existing possibilities, as depicted in Table 10.

The inclusion of vocationalized subject into general education streams cannot be expected to increase economic relevance, and does not prepare for self-employment (Lauglo 2004). According to Athumani (2003), secondary school leavers in Tanzania receive additional training before entering wage employment, and employers seem to have little interest in recruiting those with secondary education only. For Botswana, which still offers 
Table 9. Senior Secondary Curriculum Core Subjects and Options in Five Sub-Saharan Countries

\begin{tabular}{|c|c|c|c|}
\hline Country & Compulsory core subjects & $\begin{array}{l}\text { Options/streams/ } \\
\text { biases/programs }\end{array}$ & Choice \\
\hline Botswana & English; Setswana; Mathematics & $\begin{array}{l}\text { Humanities and } \\
\text { Social Sciences, } \\
\text { Sciences (Single, } \\
\text { Double, Pure) } \\
\text { Creative, technical } \\
\text { and vocational } \\
\text { Enrichment }\end{array}$ & $\begin{array}{l}\text { Minimum of } 8 \text { subjects: } \\
\text { one subject minimum } \\
\text { from humanities, } \\
\text { sciences, and social } \\
\text { sciences. In addition, } \\
\text { two subjects from } \\
\text { creative, technical and } \\
\text { vocational. One subject } \\
\text { from enrichment. }\end{array}$ \\
\hline Ghana & $\begin{array}{l}\text { English, Mathematics, } \\
\text { Integrated Science, Social } \\
\text { Science, Religious and Moral } \\
\text { Education, Physical Education }\end{array}$ & $\begin{array}{l}\text { Agriculture, } \\
\text { Business } \\
\text { (Accounting \& } \\
\text { Secretarial), } \\
\text { General (Science), } \\
\text { General (Arts), } \\
\text { Vocational (Home } \\
\text { Economics \& Visual } \\
\text { Arts), Technical }\end{array}$ & $\begin{array}{l}3 \text { or } 4 \text { choices elective } \\
\text { subjects, a variety of } \\
\text { different choices } \\
\text { offered for each of the } \\
\text { programs chosen. } \\
\text { Elective M on higher } \\
\text { difficulty level and with } \\
\text { additional topics } \\
\text { compulsory for } \\
\text { General Science. }\end{array}$ \\
\hline $\begin{array}{l}\text { South } \\
\text { Africa }\end{array}$ & $\begin{array}{l}\text { Afrikaans and English } \\
\text { compulsory; plus } 4 \text { more core } \\
\text { subjects from the groups: } \\
\text { A: compulsory language group; } \\
\text { B: Mathematics; C: Additional } \\
\text { language; D: Bible studies, } \\
\text { economics, geography, history; } \\
\text { E: TVET subjects }\end{array}$ & $\begin{array}{l}\text { General education } \\
\text { Science orientation } \\
\text { Economical }\end{array}$ & $\begin{array}{l}\text { Minimum of } 6 \text { core } \\
\text { subjects, plus } 4 \\
\text { subjects from steams. }\end{array}$ \\
\hline Tanzania & \multicolumn{2}{|c|}{$\begin{array}{l}\text { Exemplary subject choices, depending on JSE results: } \\
\text { HGL (history, geography, English); } \\
\text { ECA (economics, commerce, accountancy, } \\
\text { plus basic applied M); } \\
\text { PGM (physics, geography, advanced M); } \\
\text { PCM (physics, chemistry, M); } \\
\text { CBN (chemistry, biology, nutrition); } \\
\text { EGM (economics, geography, advanced M); } \\
\text { CBG (chemistry, biology, geography); } \\
\text { HKL (history, Kiswahili, language) } \\
\text { More subject choices are offered. }\end{array}$} & $\begin{array}{l}\text { Some of the subject } \\
\text { combinations are } \\
\text { greatly under } \\
\text { subscribed. }\end{array}$ \\
\hline Senegal & $\begin{array}{l}\text { Core subjects, except for the } \\
\text { technical stream, with different } \\
\text { allocations of time: French; } \\
\text { Mathematics; Physical Science; } \\
\text { Science of Life and Earth; English, } \\
\text { History \& Geography. }\end{array}$ & \multicolumn{2}{|c|}{$\begin{array}{l}2 \text { language streams ( } 67 \% \text { of students); } \\
2 \text { science and } 1 \text { technical stream }(\sim 28 \%) \text {; } \\
1 \text { economy stream }(\sim 5 \%)\end{array}$} \\
\hline
\end{tabular}


Table 10. Existing Links Between Education and Vocation in Sub-Saharan Africa

\begin{tabular}{ll}
\hline Link between education and vocational area \\
\hline Primary level & Inclusion of cultural and local crafts and skills in the upper primary \\
& curriculum to equip primary school leavers with low level work skills \\
& applicable in their immediate local and cultural environment, e.g. \\
& Ghana. A probably non-intended side effect is the reinforcement of \\
& cultural traditions. Resulting occupational work opportunities are \\
expected to be low-paid.
\end{tabular}

vocationalized subjects at both junior secondary and senior secondary level, additional specialized vocational education is a requirement to find wage employment. Good marks from general education perceived as proxies for being "bright" and "hardworking" and "able to learn on the job" may count more for finding jobs than vocationalized education (Lauglo 2004).

General secondary education at the larger level can contribute to the economic relevance of secondary education by increasing the scope and quality of educational outcomes like language proficiency, numeracy, methodological and social skills, and improved working attitudes. Guidance and counseling may tackle the historically negative attitudes towards manual work, although this depends on societal changes in the perceptions of values. Other specific skills directly related to a particular occupation are best taught in specially designated TVET settings (school, apprenticeships), although the TVET section across SSA is in needs of quality improvements. 
Countries with vocationalized subjects as part of the junior secondary and/or general senior secondary curriculum may discuss the continuation of these subjects in the light of the following arguments:

Selection of vocationalized subjects is limited to students from poor families, while students from better endowed families can choose academic subjects.

Dropping the vocational subjects relieves the pressure of a burdened curriculum, and provides space for the gradual inclusion of different teaching approaches geared towards delivering a wider range of skills.

Vocational subjects are not cost-effective and reduce already scarce resources, particularly in perspective of the need to increase language skills and numeracy. According to Lauglo (2004), theunit costs per student per subject for the vocationalized subjects in Botswana are between 2.5 and 4 times as high as compared to other subjects, and in Kenyan schools the ratios between 5.6 and 14.5 are even higher (the ratio for sciences of 1.4 in Botswana, and 3.8 in Kenya, but 1.4 and 1.5 only for agriculture in both countries).

The logistics attached to the facilitation and teaching of vocationalized subjects are very complex and not easy to be maintained and sustained; particularly for an educational system that intends to expand dramatically.

Teaching of vocationalized subjects requires sufficiently trained and competent teachers, and a lack of those will have a more serious impact on the quality of the subject as in other subjects.

The following checklist provides for arguments to continue vocationalized subjects as part of SE. The sometimes alleged positive impact of vocationalized education on economic development, increased entrepreneurship, and easing the transition into wage employment have been largely refuted and are therefore not represented.

The contra arguments can be refuted.

The secondary system is well functioning and well resourced, and the inclusion of vocationalized subjects will not depend on donor funding.

Vocationalized subjects may teach respect for manual labor (although this is a two-way street with disrespect for manual labor affecting vocational education: a headmaster in Ghana has remarked about the use of the word "carpenter" as an insult among students).

The syllabi for the vocationalized subjects can be developed appropriately in respect to the requirements for quality instruction.

Vocationalized subjects may count towards admission into related fields at higher education, including that the selection at the school level is not paired with other subjects that in effect bars access to higher education.

The occupational segment for which the vocationalized education would be preparatory is large enough to offer potential work opportunities, which may particularly apply for business subjects and agriculture.

The decision about vocationalized subjects should be based on appropriate discussion and acceptable levels of agreement within society, and acknowledge the human, organizational, financial capacity, and the implementation requirements. 


\section{Technical and Vocational Education and Training}

\section{Starting Points for TVET}

\section{TVET Trends and Patterns}

SSA countries currently follow a similar approach to technical and vocational education (TVET). In contrast to vocationalized education, technical and vocational education and training (TVET) refers to specialized education for and about a particular occupation or occupational area. Ideally, vocational education aims at education through the occupation. Within the limitations of existing differences in context in SSA countries, the following trends and patterns can be observed for TVET in SSA:

Education is increasingly regarded as 'holistic', and TVET should be included as part of SE. SSA educational systems strive for horizontal (from and to general education) and vertical (from junior secondary into senior secondary into tertiary education) mobility within the educational system. The wall between general education and TVET stands in the way of integration of TVET into secondary education.

The general public considers TVET secondary education as inferior to general secondary education. Where opportunities for TVET and academic SE exist next to each other, one needs to caution against selection processes disadvantaging students because of familiar background, ethnicity, location, or gender.

- Primary school leavers increasingly compete with JSE schools leavers, who in return compete with SSE school leavers for both TVET and job opportunities.

Unemployment rates are high. Job opportunities for skilled labor in the SSA are scarce. Employers seem to increasingly opt for secondary education qualifications and specialized vocational education before offering employment. Enabling students 
to become self-employed and entrepreneurs is regarded an important component of TVET.

To alleviate the lack of educational opportunities in the past, and to better use the existing experiences and knowledge in a society, countries increasingly aim to recognize prior learning (RPL), which in fact means recognizing non-standardized competencies gained in informally trained employments and occupations.

TVET in SSA countries is fragmented. Private vocational training institutions proliferate. The lack of clear training and assessment standards and standardized qualifications question the quality of education. TVET and TVET assessment are in need of standardization. TVET learning programs should be organized in units or modules that focus on the attainment of certain competences or skills. Qualifications are described as competencies or skills, which need to be achieved by the student. Skills and competencies are categorized in qualification levels building up on each other, for example, level 1 foundation skills, level 2 intermediate skills, level 3 advanced skills.

It is generally perceived that employees need to be flexible, and that they will not be in the same position for the rest of their life. As a result, TVET shifts to prepare students in a particular occupational sector rather than for a particular job.

In contemporary SSA, the structural organization of TVET to unify and at the same time integrate vocational education into the secondary education sector is the main challenge. Unification of TVET and integration of education are two sides of one medal with numerous but different implications. Experiences gained from South Africa and Botswana show that unification and integration are mammoth tasks for each educational system with enormous practical challenges.

The unification and attached challenge of quality assurance for the TVET sector is a prerequisite for the provision of any TVET. The aim of quality assurance is to provide for reliable, valid, accountable and comparable standards, assessment instruments, qualifications, and certification; in short to assure for the quality of each that together add up to quality education. The issue of assessment and examination is closely connected to issues of qualification frameworks, and a demanding task. Botswana has spent more than six years and extensive external support to establish quality assurance that covers parts of its TVET program.

The integration of education requires a key political decision about the boundaries and differentiation between general education and TVET. Part of the challenge is to combine and coordinate educational sectors (general secondary education, vocational education, tertiary education) that are part of the portfolio of two or even more ministries; for example, Ministry of Education and Ministry of Labor.

SSA countries have responded to the new task of organizing and managing a national qualification framework (NQF) by establishing new parastatals or agencies into existing structures which are already challenged for their low levels of effectiveness and communication in its organization and management. Efforts of restructuring are prone to further inflate already inflated organizations, and to rather add challenges than solving existing ones. The discussion in Chapter 9 on capacity building (particularly context characteristics) equally refers to the restructuring and integration of TVET. 


\section{Entrepreneurship, and the Formal and Informal Economy}

One of the substantial expectations on curriculum reform in SSA is to reduce the high rates of unemployment. The civil service or parastatals in SSA no longer provide the principal entry into the labor market. It is not likely that the majority of secondary school leavers will find formal employment. There is hope that more qualified labor may be absorbed by qualified job demands to come, and that curriculum reforms enable students to become entrepreneurs and self-employed. In many SSA countries, the term "entrepreneurship" in the current African situation is a rather euphemistic term, and should not be mistaken with "seemingly creative job alternatives fashioned voluntarily to escape the conventionality of salaried positions in corporate structures" (Lauer 2000). Realistic self-employment in current African economies mainly refers to the informal sector, and McLean (2000) goes as far as describing development of the informal sector as no economy at all, but the desperation of impoverishment. Al-Samurai and others (2003) in their cross-country study of four African countries state that the self-employment among school-leavers and graduates was quite high and growing over time, but that incomes from wage employment are generally much higher than earnings from self-employment.

The political expectations on entrepreneurship (self-employment, establishment of enterprises, job creations) are high. Entrepreneurship in this ambitious understanding hinges on surrounding conditions and framework to enable self-employment that develop concurrently to socio-political developments. The contexts and requirements of entrepreneurship in formal or informal setting are quite different. The development of entrepreneurial attitudes, commonly regarded as a requisite for self-employment, have different mouldings for targeting formal or informal economies. Equally, the extent of economical knowledge to function in informal or informal economies differ. The present provision of entrepreneurial program components as part of TVET curriculum reforms appear to be rather vague, probably because the theoretical framework for their development is vague about the setting towards which the self-employment intends to be directed.

\section{TVET Quality}

In addition to constraints of social reputation and lack of job opportunities, present constraints on the attractiveness of TVET are the comparatively high school fees charged for vocational education (in comparison to the lower fees in general education), employers' preferences for secondary school graduates, and the actual and perceived lack of quality of TVET. Regarding increases in quality, the discussion about teaching and learning approaches, curriculum development, coordination between curriculum and assessment, and questions of professional development and capacity building are similar to the discussions on general secondary education in this report.

For TVET in more detail, the specialized vocational area skills (job skills) for most occupations can only to a limited extent be taught and simulated in training institutions. Quality TVET requires students' to practice in realistic workplace settings. On-the-job training and work-place learning provide for experiences and consolidation of skills (work ethics, workplace reality) that the training institution can only offer to a limited extent. Experiences from Botswana indicate that it is difficult to provide opportunities for workplace learning because of limitations in space and support of trade and industry. 


\section{Unification of TVET}

Across SSA, the present provision of quality TVET exists on a limited level only. Where existing, it is scattered and marked by fragmentation and lack of organization, or marked by its fragmented and scattered past. While the structures and experiences with general secondary education exist in each SSA country, for most countries (with some slight exceptions, for example, Botswana) the establishment of TVET as part of organized secondary education is a more novel task. Botswana has spent five years and immense efforts and funding on the establishment of a TVET structure at SE level (the BTEP: Botswana Technical Education Programme), built upon and re-organized from existing structures of formerly named vocational training centers (VTC). While considerable progress has been made particularly in quality assurance and re-structuring, more challenges are still ahead, such as for teacher education, further integration of other existing vocational education structures (the brigades). The Botswana example tells about the magnitude of the task to provide and unify TVET, which will be even higher for countries where nationally organized quality TVET presently refers to more of an ambition or theory than to reality. The already enormous task of unification does not yet include the additional tasks deriving from aims of integration.

Because of the differences in pre-conditions and context, and the restructuring of TVET needs to be discussed in a different light than general SE. Across SSA, various public, semipublic, and private institutions provide TVET, in different quality and with different qualifications. Non-institutional apprenticeship programs exist in addition to more institutionalized TVET. Most countries lack clear frameworks for the accreditation and quality assurance of existing TVET providers. Fragmentation and inconsistent qualification system lead to confusion and lack of comparability of learning outcomes. In many SSA countries, more than one ministry, particularly the two Ministries of Education and Ministries of Labor, share the responsibilities for examination and qualification of vocational education; in Ghana it is even spread across six ministries. The unification of TVET in SSA requires solutions to:

The need to accredit and register TVET providers and to ensure that quality education is delivered;

The need to develop appropriate curriculum and examination requirements for TVET providers (which depends on the skills to be provided);

The setting, administrations, and quality control of appropriate examinations, and the awarding of comparable qualifications along a set of unified standards; and The organization of qualifications in a unified TVET framework that ensures comparability and continuation.

\section{Qualification Frameworks and Integration}

\section{Integration}

The mobility between vocational education and academic education in most countries of SSA is limited, as it is in many educational systems in this world. Most TVET qualifications are not recognized as entry qualifications for the academic system. Where they are recognized theoretically, they do not necessarily in reality. To allow for more horizontal (into and from general education) and vertical (into tertiary education) mobility, SSA countries 
aim to establish a unified qualification framework. The highly critical knot in this endeavor is the key decision about the boundaries, which establish a differentiation between general and TVET. SSA countries have developed or are currently in the process of developing different solutions to this. South Africa has already established its National Qualification Framework (NQF), Botswana is in the process of establishing a National Vocational Qualification Framework (BNVQF), and Ghana and Tanzania aim at establishing a qualification framework not yet completely specified for its scope of integration.

The existing or anticipated frameworks are based on two characterizing models of differentiation based on two fundamentally different objectives:

They either attempt to encompass all primary, secondary, vocational, and tertiary education in one unifying framework to allow for mobility across all sectors (the NQF in South Africa), thereby not differentiating between TVET and academic education (as in Australia, Canada, England, New Zealand, and the United States). Or they attempt to differentiate curricula and institutions of TVET and of general education as a dual system (for example, Ghana). This model basically follows the German and Francophone practices, as in Senegal. The distinctions between the first exit point for continuation into TVET mark the differences within the model and the countries named.

\section{Trends and Patterns of Integration}

The issue of a unified National Qualification Framework (NQF) in SSA resonates with the language, policies and practices of international education and experiences, particularly of the industrialized countries of UK, Scotland, and New Zealand. Policies in SSA increasingly followed these during the 1990s, suggesting the establishment of inclusive qualification frameworks for SSA that would integrate general and vocational education and training awards in a single system to cover all levels of qualifications. Chisholm (2005) locates the origins of the NQFs in competency-based frameworks, and the shift from provider to employer-led training. Initially borrowed from educational conservative 'Northern' ideas, the NQF in South Africa in contrast to its conservative origin has a strong progressive association, and has been implemented in South Africa's particular context of 1994. In the course of local transformations of the NQF in South Africa over the years, South African NGOs and consultants have expanded the idea of the NQF 'into Africa', amongst other things, via regional conferences (Chisholm 2005). The first Southern African Development Community (SADC) Protocol on Educational Training in 1997 adopted the new key figure of South African education: the NQF. One of the principles articulated in the SADC protocol is the importance of developing equivalence of qualification within the region, and a Technical Committee on Certification and Accreditation has been established under the protocol. Planning has begun to develop a SADC Regional Qualifications Framework. By 2004, a number of SADC and SSA countries (Botswana, Tanzania, Ghana) are formulating qualification frameworks with a strong vocational slant. Yet it is surprising that the idea of a national qualification framework that in the country of SSA origin itself (South Africa) has been considerably transformed and very much rejected because of its proven complications and ineffectiveness, is seemingly exported to other countries as the potential solution to the problems it does not solve in its country of origin. 
Figure 4. Three Integration Models for TVET

\begin{tabular}{|c|c|c|c|c|c|c|}
\hline \multicolumn{3}{|c|}{ Existing structures, point of departure } & \multicolumn{2}{|c|}{$\begin{array}{l}\text { Option } 1 \text { (e.g. Ghana, roughly the } \\
\text { French and German model) }\end{array}$} & \multicolumn{2}{|c|}{$\begin{array}{l}\text { Option } 2 \text { (e.g. South Africa, } \\
\text { following the Anglo-Saxon model) }\end{array}$} \\
\hline \begin{tabular}{|l|} 
Tertiary \\
(universities, \\
teacher \\
education)
\end{tabular} & $\begin{array}{l}\text { Poly- } \\
\text { technics, } \\
\text { business } \\
\text { studies }\end{array}$ & & $\begin{array}{l}\text { Tertiary } \\
\text { education }\end{array}$ & $\begin{array}{l}\text { Open } \\
\text { Colleges } \\
\mathbf{4}\end{array}$ & \multicolumn{2}{|c|}{$\begin{array}{l}\text { Tertiary education (universities, } \\
\text { teacher education, former } \\
\text { polytechnics) }\end{array}$} \\
\hline $\mathbf{4}$ & 4 & & 4 & i & 4 & 4 \\
\hline $\begin{array}{l}\text { General } \\
\text { sec } \\
\text { education }\end{array}$ & $\begin{array}{l}\text { Institutiona- } \\
\text { lized } \\
\text { TVET }\end{array}$ & $\begin{array}{l}\frac{0}{\bar{E}} \\
\frac{0}{0} \\
\frac{0}{0} \\
\frac{0}{0} \\
\frac{0}{20} \\
\frac{0}{0} \\
\end{array}$ & $\begin{array}{l}\text { General and } \\
\text { technical- } \\
\text { professional } \\
\text { secondary } \\
\text { education }\end{array}$ & $\begin{array}{l}\text { Pure technical } \\
\& \text { vocational } \\
\text { education }\end{array}$ & $\begin{array}{l}\text { General } \\
\text { secondary } \\
\text { education }\end{array}$ & $\begin{array}{l}\text { Technical and } \\
\text { vocational } \\
\text { education }\end{array}$ \\
\hline 4 & 4 & $\mathbf{4}$ & 4 & 4 & 4 & 4 \\
\hline \multicolumn{3}{|c|}{$\begin{array}{l}\text { Basic education (respectively } \\
\text { primary education) }\end{array}$} & \multicolumn{2}{|c|}{$\begin{array}{l}\text { Basic education (respectively } \\
\text { primary education) }\end{array}$} & \multicolumn{2}{|c|}{$\begin{array}{l}\text { Basic education (respectively } \\
\text { primary education) }\end{array}$} \\
\hline
\end{tabular}

\section{Models for Differentiation}

The all-inclusive model of the South African NQF dominates present development discussions in other SSA countries. Other models exist in theory and practice. Figure 4 approximates structures and conditions to show three simplified models for differentiation. For many SSA countries, the left model marks the closest point of departure, and the middle and right side models depict the choices.

The differences between the two options (middle and right) may at first look minimal only, but the subsequent practical implications are far-reaching. The similarities between both models are:

Basic education (respectively primary) marks the first exit point. Independently of the future paths of students, all students need a minimum set of skills to continue in society and economy. All responsibilities for provision and quality assurance rest with Ministries of Education.

Post-basic education increases access for students, SE is not necessarily meant as a pathway into academic and/or tertiary education only.

All post-secondary TVET at both Universities and Polytechnics (or what used to be Polytechnics in some countries) is categorized as tertiary education. The pathway to tertiary education allows for access from both general SSE students, and TVET secondary education students. Examinations and qualifications for general but and for vocational SE must be of comparable standard and reliability.

The two models (middle and right) are importantly distinguished by the differentiation respectively lack of differentiation between TVET and general education. The middle model is marked by:

The terminal character of a rather pure TVET, for example, apprenticeship courses and industrial crafts. The curriculum for graduates from the pure TVET does not 
include learning outcomes particularly in English, mathematics, and the sciences, at least not on the general level qualifying for tertiary education. Graduates from this stream do not automatically have the possibility to continue into tertiary education. If they wish to do so, they have to individually and additionally add on qualifications assessed via external examinations. At the same time, general senior secondary education offers different streams of academic education and "technicalprofessional" TVET;

The technical-professional TVET caters for minimum levels of general skills in English, mathematics, and the sciences. Graduates are qualified to continue into tertiary education, which realistically means into technical and business tertiary education.

The finer details of both models will be discussed along the example of the planned qualification framework for Ghana, and the NQF of South Africa.

\section{The Qualification Framework in Ghana}

The qualifications framework in Ghana is still under development. Its proposed structure is presented in Figure 5 below. The Basic Examination Certificate in Education (BECE) marks the first exit point. The examination is delivered and certified by the Ministry of Education (MoE). Successful graduates compete for various courses offered at senior secondary schools that offer both academic education and institutionalized technical and vocational education. Graduates of all of the before mentioned streams qualify of tertiary education, although in different areas. Industry-based apprenticeship courses are alternative routes for BECE graduates (although not qualifying for tertiary). Primary school leaver dropouts, unsuccessful BECE candidates, and BECE candidates unsuccessful for either secondary schooling or apprenticeship are left with pre-vocational skills.

Figure 5. Attempted Qualifications Framework in Ghana

\begin{tabular}{|c|c|c|c|}
\hline $\begin{array}{l}\text { School } \\
\text { grades }\end{array}$ & $\begin{array}{l}\text { Education } \\
\text { cycle }\end{array}$ & \multicolumn{2}{|l|}{ Education providers } \\
\hline & \multirow[t]{2}{*}{ Tertiary } & $\begin{array}{l}\text { University/ Polytechnic/ Technical University/ } \\
\text { Professional Institutes/ College of Education/ } \\
\text { Teacher Education }\end{array}$ & \\
\hline & & $\mathbf{\alpha}$ & \\
\hline \multicolumn{4}{|c|}{ Second exit point: Transition requirement Senior Secondary School Examination Certificate } \\
\hline \multirow[t]{2}{*}{12} & \multirow[t]{2}{*}{$\begin{array}{l}\text { Secondary } \\
\text { education }\end{array}$} & $\begin{array}{l}\text { Specialisation in Grammar (academic)/ Technical/ } \\
\text { Agricultural/ Vocational programme. Same } \\
\text { minimum level of exit skills for E, M, S. Secondary } \\
\text { qualification. }\end{array}$ & $\begin{array}{l}\text { Apprenticeship/ skills training. } \\
\text { National craft and business } \\
\text { certificates. }\end{array}$ \\
\hline & & $\mathbf{A}$ & $\mathbf{T}$ \\
\hline \multicolumn{4}{|c|}{ First exit point: Transition requirement Basic Examination Certificate in Education } \\
\hline 9 & $\begin{array}{l}\text { Basic } \\
\text { education }\end{array}$ & $\begin{array}{l}\text { Basic education ( } 6 \text { years primary, plus } 3 \text { years junior } \\
\text { basic literacy, numeracy, science, and social studies }\end{array}$ & $\begin{array}{l}\text { condary): general curriculum for } \\
\text { ECE. }\end{array}$ \\
\hline
\end{tabular}


Figure 6. The National Qualification Framework in South Africa

\begin{tabular}{|c|c|c|c|}
\hline $\begin{array}{l}\text { School } \\
\text { grades }\end{array}$ & $\begin{array}{l}\text { NQF } \\
\text { Level }\end{array}$ & Band & Qualification type \\
\hline & $\begin{array}{l}8 \\
7 \\
6 \\
5\end{array}$ & $\begin{array}{l}\text { Higher } \\
\text { Education } \\
\text { And Training }\end{array}$ & $\begin{array}{l}\text { Post-doctoral research degrees, Doctorates, Masters degrees } \\
\text { Professional qualifications, Honours degrees } \\
\text { National first degrees, higher diplomas } \\
\text { National diplomas, National certificates }\end{array}$ \\
\hline \multicolumn{4}{|c|}{$\begin{array}{l}\text { Transition requirement: Further Education and Training Certificate (FETC) for Technical University (former } \\
\text { Technicons, and matric (three subjects passes) for universities }\end{array}$} \\
\hline $\begin{array}{l}12 \\
11 \\
10\end{array}$ & $\begin{array}{l}4 \\
3 \\
2\end{array}$ & $\begin{array}{l}\text { Further } \\
\text { Education and } \\
\text { Training (FET) }\end{array}$ & National certificates \\
\hline \multicolumn{4}{|c|}{$\begin{array}{l}\text { Transition requirement: General Education and Training Certificate (GETC), either via grade } 9 \text { or adult education } \\
\text { (ABET) route }\end{array}$} \\
\hline $\begin{array}{l}9 \\
1-8\end{array}$ & 1 & $\begin{array}{l}\text { General Education } \\
\text { and Training (GET) }\end{array}$ & $\begin{array}{l}\text { Grade 9, ABET level 4, National certificates } \\
\text { ABET (Adult Basic Education and Training) levels 1-3 }\end{array}$ \\
\hline
\end{tabular}

\section{The National Qualification Framework in South Africa}

To standardize all qualifications, and to allow for maximum mobility and progress between vocational and general education South Africa has established its National Qualification Framework (NQF) as depicted in Figure 6.

The practical challenges to the establishment of the NQF are much higher than for the dual system, and have created numerous and accumulating problems in South Africa. In practice, criticisms of the NQF in South Africa have increasingly mounted because of the numerous problems attached, and the obvious lack of effectiveness. Young (2004) suggests that the NQF has created more problems than it has solved. He states that a basic fallacy of the notion of the NQF is the fallacy that education or qualifications can compensate for society and social inequalities. The NQF did not provide for quicker progression up the educational ladder, mainly because they cannot on their own do much to increase the demand for skills and overcome deeply rooted inequalities that make for skill and educational differences (Chisholm 2005; Young 2004). The absence of a linkage between the qualifications and provisions, as it is argued, is a particular problem for developing countries where qualifications may proliferate but there is no provision leading to them. The major problems with NQFs are not lack of resources or resistance, they are principally political, administrative and technical or professional.

Political difficulties are from the establishment of entities outside government with great power; administrative difficulties arise from the proliferation of new agencies and committees concerned with quality assurance, standard setting and assessment that NQFs invariably generates. They frequently have difficulty in recruiting members and staff with appropriate expertise. Technical or professional problems relate to the relatively straightforward activity of setting and marking examinations, and for the need for new language of standards, units and levels to define criteria that have to apply to very different qualifications. (Young 2004)

While the idea of NQF extends from South Africa into other parts of Africa, in South Africa it has already been the subject of a departmental review. 


\section{Implications of Frameworks}

The implications created by the frameworks leave many questions open. These include:

Who is responsible for the provision of which education, and for the definition of the standards of the learning outcomes? Areas of conflicts arise concerning the responsibilities for the technical-professional provision, and the standard definition of institutionalized SE now offering TVET. Commonly, the Ministry of Education (MoE) oversees SE, but the usual responsibility for the professional-technical domain rests with the Ministry of Labor $(\mathrm{MoL})$, or even other ministries. Vice versa, traditional TVET now incorporating general knowledge (such as English) for students to qualify for tertiary education are occupied with traditional responsibilities of MoE. While in some areas the answer may be theoretically easy (for example, MoE responsible for general English, MoL for carpentry, independently where taught) but practically difficult, the answer is less easy and practically even more difficult when it comes to the development and comparison of specialized subject matter, such as academic Mathematics for general secondary education, and Mathematics applied in electronics for TVET.

What are the required entry qualifications for continuation into subsequent education? The challenges arise when students wish to cross over into other areas of education, for example, a TVET secondary student wishing to continue with biology at the University, or a student teacher whishing to switch to engineering at polytechnics or technical universities.

Who measures which learning outcomes and where? The overlap in ministerial responsibilities leads to overlaps in the definition and measurement of learning outcomes: hence, while the MoL may be more related and influenced by a certain industry and therefore may promote different learning outcomes or learning outcomes closer to industrial norms, the MoE may pursue differently structured learning outcomes.

What are the qualifications offered, and how are they valued? Particularly with the inclusion of technical-professional TVET as part of institutionalized secondary education, and the upgrading of former technical high-schools and polytechnics to tertiary education institutions, it is questionable how formally equal qualifications are valued in reality. This refers to both continuation into further education (such as sought-after university courses), but as well to acceptances on the job market.

The answers to these questions depend on the context of the country, the political will, and the choice of the boundaries. However, with so many open question and daring challenges, the feasibility, practicality, expected effectiveness, and exiting realities are strong criteria for decision-making. One of the existing realities is that in practice the maximal mobility within the education system will always be limited.

Independently of the choice, experiences in SSA (Botswana, South Africa) have highlighted the intense complexity and considerable difficulty involved in TVET integration. Attempts at integration demand political communication and consensus, and the will to solve overlaps in ministerial responsibilities. Due to the novelty of the task Highly qualified 
manpower to plan and develop curricula, qualification frameworks and human resources (administrators, teachers, and lecturers), and an adaptable implementation process are many more challenges occurring.

As a more detailed guideline, any qualification framework essentially needs to provide for:

The categorization of competencies or outcomes that require clear descriptions of levels of required achievements (standards);

Valid and reliable assessment instruments for measurement of standards across the range covered in the qualification framework;

Valid and accountable assessment of competencies or outcomes (application of the assessment instruments);

Accountable recognition and certification of qualifications;

Accountable recognition and certification of institutions offering the education across the range covered in the qualification framework (vocational; or vocational and general secondary; or vocational, general secondary and tertiary); and

Organization and management of the qualification framework itself. This is particularly difficult and complicated because the responsibilities and competencies of the qualification framework cuts across the competencies of ministries, and across various ministerial departments or parastatals (vocational education, secondary education, tertiary education, curriculum development, assessment, registration of qualifications). 


\section{Operational Curriculum: Current Trends in Instructional Methodology}

\section{The Need to Move Toward More Active Teaching and Learning Approaches}

Numerous research documents, interviews, and observations describe present learning in SSA classrooms as being limited to low-level learning of pure memorization of facts. The main argument is that quality learning is largely restricted because the teaching and learning approaches and methodologies in classrooms are focused in transfer of knowledge from the teacher to the class. Care should be taken to not simplistically equalize "chalk-and-talk" teaching with the low-level learning of the majority of present SSA classrooms. Yry, even the chalk-and-talk methodology is often not reaching its full potential as better implementation in the classroom could possibly result in much better learning than is currently the case. The quest for increased quality in learning should therefore focus on improvement of current teaching and learning approaches, as well as on more modern approaches. The latter have been introduced as part of recent curriculum reform processes in SSA. Other classroom factors contributing to low-level learning need to be addressed, for example, teachers' content knowledge, levels of motivation, and school culture. They will be discussed in the sections to follow.

\section{Active Learning and Learner-centered Education}

At the heart of every "modern" curriculum reform (Botswana, Tanzania, Namibia, South Africa, Uganda, planned for Senegal) is the notion of active learning. Active learning, or learner-centered education (LCE) as it is commonly known is SSA, is considered an effective antidote to the prevalence of teacher-centered instructional classroom practices, which 
is widely claimed to support passive learning, and the stifling of critical and creative thinking (Rowell and Prophet 1990). The promotion of LCE is directly associated with high development ambitions, such as economic development in Tanzania and Uganda, or social restructuring in Namibia and South Africa.

LCE fits well modern pedagogical ideals for focusing on the provision of a platform for developing knowledge, skills and competencies for innovation, social development and economic growth. LCE requires a move from the commonly pure content learning and the memorization of facts to the ability of learning-to-learn, to the inclusion of methodological and social skills and competencies into the learning process, to the understanding of generic higher order concepts. The pedagogical idea is to provide students with an opportunity for active engagement with learning matter for them to build knowledge themselves, instead of them simply reciting fact. The underlying methodological principles for improved and adapted classroom activities are generally understood around the terms of learner participation, activity-based education, emphasis on relevance, holistic development, critical thinking and integration of knowledge.

The theoretical framework around LCE is fairly undisputed. The focus of this modern pedagogy brings the following classroom and school culture features to the fore:

Active learners building knowledge by themselves;

Teachers making decisions about what to teach and how to teach;

Relative importance of activity and skills as a basis for acquiring knowledge;

Relative importance of induction over deduction;

Active students becoming more visible;

Teachers being less dominant in the classroom though required to be very active in prerequisite lesson design and preparations;

Teachers changing from provider of knowledge to an active coach and facilitator;

Learning and learning outcomes to be personalized; and

Outcomes of learning to be conceived of as skills, often generic skills, and not to be based on recall and memorization of facts.

\section{The Reality of Classroom Instruction and Learner-centered Education}

Several studies indicate that implementation of learner-centered education in the classroom is problematic (Jansen 1999; Chisholm 2000; Leyendecker 2002b; Ottevanger 2001).

Where SSA countries have attempted to implement learner-centered education, the actual instructional processes were largely far removed from the ideal. One of the problems is that the teacher is regarded by the societies and culturally determined understandings of authority and teaching, including students' perceptions, as the provider of knowledge and the bearer of authority. These perceptions and the resulting classroom behavior will not change overnight. Although Prophet's report dates back to 1995, his observation that teachers rather adapt their teaching to suit their and their students "world view" and perceptions on teaching, is continuously repeated and supported by other studies (for exmaple, Koosimile 2005).

A second problem with the introduction of LCE can be exemplified from South Africa. There, the implementation of the C2005 showed a clear mismatch between the meaning 
of the curriculum, and teachers understanding of the concept of LCE. A learner-centered teaching and learning methodology is too far removed from the current practice to easily bridge the gap between old and new. Jansen (1999) remarks that the complex paradigm shift required to adapt to the philosophy of learner-centered education was reduced to oversimplified dichotomies such as "teacher-centered" (old and undesirable) and "learnercentered" (new and esteemed). The oversimplification does not comply with the need for teachers to understand the complexity of the underlying concepts, and the purpose of the methods to be applied. For LCE in reality, as for example South Africa reports, "there is a wide gap between what teachers say they know and what they actually do" (Chisholm 2000). Actual classroom activities differ from the intended ones. In spite of "nice jargon in curriculum documents," teaching remains traditional, teacher-centered, and content-driven.

Where in SSA concepts of LCE were attempted in classrooms, teachers embraced the form rather than the spirit and content of the ideas. The involvement and participation of students in the instructional process was rather understood in procedural terms than as something that promotes learning. What was initially intended as activity-based lessons are muscular activities rather than the intended cognitive ones. The changes occurring are limited to symbolic displays without resulting in the intended learning. Particularly the perception of group work as one of the symbolic identifiers of learner-centered education was misperceived as the core of the pedagogical shift in both South Africa and Namibia. Students were seated in groups to satisfy the demands of group work but the teachercentered instruction has not changed (Ottevanger 2001). Practical work initially meant as investigative practice is very often understood in the sense of physical or manual practice. In sciences, it is often limited towards preparations for practical exams. Where students may do practical work, it seems to be more in the line of re-producing a given experimental schema (more or less equal to reproducing facts), and less on the actual application of an experimental methodology. Instead of contextualising learning or engaging students with learning, it is often executed as rote repetition of given practical experiments, which does not necessarily lead to the acquisition of higher cognitive skills.

A third problem is that, contrary to the pedagogical ideal, the vast majority of students are not very active and visible, probably because they have never given the chance. Although there is little research about students' experiences of curriculum reforms, numerous comments and observations point to the fact that students struggle with their new roles, which they are assigned by the intended curriculum changes. Students frequently share with teachers a common perception about what it means to teach, and are resistant to changes not fitting this perception. What is more, students' attitudes concerning learning and discipline have embraced aspects of international youth cultures. Students welcoming the opening of classrooms and the change from strict classroom organization and discipline, have problems in meaningfully filling the added space and freedom. Students are powerful influencers of change, and can be obstructive if the required attitudes and instructional practices do not fit their expectations. While the intention of the changed classroom structure for students is to become the more self-reliant, mentally active and responsible learner, this currently seems to happen only in limited occasions. Problems arise if students are not gradually directed towards the opening up of classrooms, and if teachers do not succeed in motivating students and getting them to accept their new responsibility. The unwelcomed result seems to be a laissez-faire classroom, which amalgamates with the changed societal perceptions on discipline, and amounts to confusion and even lower-level learning. 
Across SSA, teachers and headmasters at the JSE and SSE cite discipline problems as serious and frustrating problems for learning and classroom management, particularly in urban centers. The problem of shifting cultural values and orientation cannot be solved in schools alone. Disenchantment with the perceived value of education as a benefit for ones future living adds to the increasing lack of students' motivation.

Both student and teachers cannot jump from the current classroom situation and culture to a desirable ideal behavior. However, both can gradually grow and adapt to the new roles that are beneficial to teaching and learning. For such a process of growth to take place, support structures should to be available, but these are often absent or very limited in scope and time lines.

\section{The Implementation of LCE}

The immediate application of learner-centered education is beyond the reach of most current educational systems in SSA. The modern pedagogies attempted may be appropriate for a few private schools, but for the majority of African teachers and African classrooms they are not suitable. While it must be stressed that a departure from current teaching and learning approaches is both needed and feasible for SSA classrooms, a simple jump-in-one to LCE is not achievable. Classroom practices change rather by progress than by replacement. This is an important understanding for implementation approaches and professional development: change cannot mean the substitution of one existing system with another more desirable one, it means improving and building on the existing conditions. This fundamental tenet is neglected because of the presently often applied logic in SSA curriculum reform that prescribes instructional processes to reach the desired learning outcomes expected to then lead to ambitious educational goals: instructional processes are linked to learning outcomes, learning outcomes are linked to educational goals, and educational goals are linked to policy goals. However tempting this logic may be, it does not work. The same fact is indicative to one of the major practical problem in educational and curricular change: the need for compatibility of ambitions with actual context and learning culture is often overlooked or underestimated. Instead of focusing on far-reaching ambitions, reform needs to be based on the practical changes that can be made from existing conditions.

In more detail, the main practical challenges for the improvement of instructional quality that are frequently neglected for the development of curricula are that:

Teachers need to have sound knowledge of the content matter to be flexible to adjust to different ways of student thinking, and to be able to relate to the emerging questions and problems without being challenged in his position. Due to their own learning experiences and education, the content knowledge of many teachers in SSA classrooms is limited.

Teachers need to have a sound knowledge of instructional methodologies, their aims and potential. Teachers need assistance and space for learning about instructional methodologies.

Teachers' roles change from providers of knowledge to facilitators, and the changes in roles need to be both comprehended and accepted by teachers, students, and the society alike. 
Classrooms management change to more open forms, questioning the traditional role and authority of teachers, and often the cultural relation between "young" and "mature." Problems with discipline may occur, and add up to the widely increasing discipline problems in African classrooms due to changes in societies.

Teachers' workloads are likely to increase significantly, at least in the initial stages of implementation because more time is required for lesson preparations.

The suggested solution to these practical problems that need to be addressed for any reform attempt will be discussed in Chapter 9 on professional development.

Classroom research (Geckler 2000; Ottevanger 2001; O'Sullivan 2004) indicated that learner-centered education does not fit the vast majority of current African classrooms for a variety of reasons. The gap is too wide to be bridged even in one giant step.

There are reports (however limited) of successful professional development programs (in Namibia, Tanzania, Zimbabwe, Uganda) indicating change in class interaction from teacher dominated classes to a more active teaching and learning methodology, improving the effectiveness of current methodologies. Instead of focusing on an ambitious ideal, the approach of the in-service education was to ensure effective learning using whatever activity, techniques and skills that bring about more active participation and individual work within the realities in which teachers work. The important message is not about wording. It is that there are indications of professional development programs that bring about better learning and make a difference for the student.

\section{Equity and Physical Resources}

\section{Physical Resources and Distribution of Funding}

The disparity in facilities within SSA countries is sometimes dramatic, particularly in rural areas that lack the barest necessities for teaching. Providing for equal access to quality education is linked to the definition of minimum standards of physical schools structures and resources. The lack of basic physical structures hinders teaching and implementation efforts in SSA, sometimes with unconsidered consequences; e.g. the lack of toilet doors or toilet facilities leading to girls' absences during their menstruation (Leyendecker 2002a). Many of the claims for resources are genuine. To alleviate the disparity in facilities, Ghana has classified its schools into well endowed, semi-endowed, and less endowed. In a similar line, South Africa divided its schools based on physical conditions and relative poverty of the community and the school into five categories of the poorest 20 percent, the next 20 percent, and so forth. Funds for schools in South Africa are allocated according to the categorization (for example, the poorest 20 percent receive 35 percent of resources).

In Table 11, the report extends a basic categorization of physical resources for general secondary schools from Rogan (2001) as a guideline for defining minimum standards and subsequent priority spending.

The potential of SSA countries to supply physical resources varies. For many countries, it will not be possible to supply physical facilities to the highest level in one go (Lewin $2004 \mathrm{~b}$ ). The challenge is to define the critical mass of instructional resources to make schools effective, and then to ensure the provision of equal standards of basic buildings and resources to the best level. The financing of physical resources should not take the focus off the ultimate importance of other factors (such as professional development, capacity 
Table 11. Levels of Physical Resources

\begin{tabular}{cl} 
Level & Physical resources \\
\hline 1 & $\begin{array}{l}\text { Basic buildings, classrooms and one office, but in poor conditions. Enough toilets } \\
\text { for each sex available. Some textbooks but not enough for all. }\end{array}$ \\
& $\begin{array}{l}\text { Adequate basic buildings in good conditions. Suitable furniture, adequate and in } \\
\text { good conditions. Staff-room and administration. Electricity in at least one room. }\end{array}$ \\
& Textbooks for all. Some apparatus for sciences. Walled-in ground. \\
& Good buildings, with enough classrooms and a science room. Electricity in all \\
& rooms, running water. Textbooks for all students and teachers. Sufficient and \\
& well-kept science apparatus and consumptives. Some curriculum materials \\
& others than found in the environment. Secure premises, well kept grounds. \\
& Excellent buildings with one or more well equipped science laboratories. Library \\
& or resource centre. Adequate curriculum materials other than textbooks. Good \\
teaching and learning resources; e.g. computers, models. Attractive grounds. \\
Good copying materials.
\end{tabular}

building, and management). The Pisa report 2005 for OECD countries states that disadvantaged schools objectively carry higher burdens as compared to advantaged schools, but for progressing on students' learning it counts more if schools cultures are conducive or not. The value of resources should not be underestimated, yet the use of financial constraints and lack of resources as overall excuses for poor and unmotivated teaching should be avoided. Even at lower levels of physical resources a qualitative improvement in teaching may be achieved. Physical resources directly impact on the potential of a school, but it is the teaching rather than the resources that make a difference in the quality of education.

\section{Further Curriculum Issues Influencing Instructional Quality}

\section{Time on Task}

The matter of instructional time in SSA deserves high attention. The length of instructional time is a matter of considerable significance and a strong indicator of students' access to learning opportunities. The positive correlation between instructional time and students' achievements appears to be even stronger in developing countries (Fuller and Clarke 1994).

Intended instructional time is not the same as actual learning time. Studies in developed countries (for example, Doll 1996) reveal disparities between intended instruction time in the curriculum, actual time allocated in schools, the time learners spend actually learning (time on task) and the time they spend in situations where students and learning material are well matched and learning occurs in a fairly ideal fashion (academic learning time). The amount of time decreases from the first to the fourth of these categories, especially in schools in poor communities (UNESCO 2005). At the same time, the positive relationships increase between students' achievements and allocated time, time-on-task, and academic learning time (Cotton 2001).

While the intended annual instructional time for SSA at the junior secondary level seems to be the highest in the world (965 hours; Benavot 2004), the time-on-task seems to be significantly reduced for a number of different reasons, e.g. low allocations of teachers' 
working-times, late coming of students or teachers, teacher and learner absenteeism for a variety of reasons, non-teaching, classroom shortages and lack of learning materials, more universal phenomena such as lack of discipline and difficulty in maintaining learners' attention, or extra-curricular activities. Probably representative or similar for many SSA countries, the report of Chisholm and others (2005) on South Africa illustrates these points. In South Africa, teachers spend less time on all teaching related activities than stipulated by policies (on average 1599 hours per annum as compared to 1720 hours). Secondly, of all of the time spent, they spend less on actual teaching (instead of the expected percentage range between 64 and 79 percent, they spend 46 percent of a 35-hour week). Teaching and working time diminish as the week progresses. Also, across SSA, the loss of time-on-task is a major constraint on efforts to improve learning. Remedies to increase instructional time need to target the complexity of national policies, organization, better school management, and accountability. Any attempt for increases in instructional quality demands for enhancing the teaching and learning efficiency of instructional time.

Time allocations at schools may be increased when the school days are lengthened. Most secondary schools in SSA operate on timetables from early morning until early mid-day. Experiences gained from boarding schools in SSA (Leyendecker 2002a) and from other OECD countries (for example, Chile; Cox 2004) indicate that full day schooling benefits students' learning. Changes to a full school day, however, require highly complex changes in the political and financial context (Cox 2004). One should caution against a formal increase in intended instructional time when the underlying problems of loss of time-on-task and quality in teaching are not addressed.

The South African example on workload and instructional time (Chisholm and others 2005) adds another dimension to the problem of instructional time. More than half of the working week is spent on administrative and non-administrative tasks, including new tasks emerging from new curricula. Teachers' workloads are perceived to increase significantly or are likely to increase as a result of educational reform, while time-on-task decreases. This is particularly because of:

New roles and expectations on teachers;

More of the same work;

More complex work;

Changes in curriculum, marking and assessment;

Changes in administrative demands;

A more diverse student population inside classrooms; or

Ironically, teachers' activities in coping with curriculum reform.

For SSA countries intending to implement substantive educational reforms, it can be expected to create similar problems, which need to be anticipated and catered for in curriculum development and adaptation of assessment.

\section{Class Size}

Overcrowded classrooms are the reality for many schools in SSA, particularly at the JSE level. There is a close relation between instructional quality, class size and teacher capacity, and teaching with 40 or more students are a demanding task even for the best teacher. 
While reductions in class size do not per se guarantee better instruction (unmotivated and/or uneducated teachers may as well teach poorly for 10 students only, or motivated teachers may teach as well for 60 students), manageable class sizes are strong factors for improvements of instructional quality.

At the SSE level, the class size for some elective subjects may be around 10 students only (for example, some physics classes in Zimbabwe; Chavunduka 2005), and may well prove the point that low class sizes do not necessarily guarantee better teaching. In countries with limited resources and limited numbers of SSE enrollment, class sizes of 10 or even below make ineffective use of existing capacities. To avoid very low class sizes may necessitate a revision of the habit that many SSE schools offer as many elective subjects as possible. It speaks as well for the need of better management and organization at both school and district level.

\section{Homework}

Homework can increase students learning time. SSA students have different time available for doing homework. Boarding school students (particularly girls) are less distracted, have less household chores, are more encouraged, and therefore use more time to do homework (Leyendecker 2002a). In some areas of SSA, the issue of gender in relation to homework is of great concern for non-boarders. After school, girls are usually engaged in household duties. The type of traditional girls' duties (preparing meals, fetching water, cleaning the house, going to the market, caring for younger brothers and sisters) may not allow for reading, boys' duties (such as looking after cattle) may well do (Leyendecker 2002a).

While it is unlikely that homework per se produces achievement gains, there is a positive association between appropriate homework assignments and achievement (AnamuahMensah 2004; Sharp 2002). Appropriate homework might develop positive attitudes towards learning, and may make students feel responsible for their own learning (Arends 1994). As well, homework is a very good instructional instrument towards application of knowledge, or for project work. Homework is effective when:

It is motivational and relevant to learning objectives, and not attached to punishment;

It is assigned regularly and in reasonable amounts;

Learner's have time availability;

It is collected and reviewed during class - the effectiveness of homework (development of attitudes, and achievement) depends strongly on the provision of feedback (Scriven 1999);

Parents support it.

The teacher is central to the kind of assignment given, and in providing feedback. Teachers marking and checking homework enforces positive attitudes, and provides information to both students and teachers. Assigning homework and providing feedback takes time and depends on teachers' commitment and professionalism.

\section{Teachers' Role}

The shift to the new educational policies requires a new set of roles for competent teachers. According to Muller (2004), with the new policies in South Africa teachers are meant to be 
learning mediators, interpreters and designers of learning programs, leaders, administrators and managers, scholars, researchers and lifelong learners, play a community, citizenship and pastoral role, and be a learning area specialist. The seven roles for teachers represent a significant advance from the narrow notion of a teacher as subject specialist and content transmitter. There is a huge gap between the ideal and the reality. Few teachers manage to be all these because this jump from one level to another more ambitious one cannot be made for the vast majority. As well, teachers will only be motivated to make any jump if they are motivated to do so. Teachers working conditions, the definition of professional standards, and school culture are important parameters for motivation.

\section{Curriculum, Teacher and Learner Support Materials}

The value of curriculum support material is of particular value in the SSA context where teachers need assistance with contextualising content (Dlamini, Coenders, and Stronkhorst 1995). Particularly during initial stages of implementation, and/or where teachers are expected to transfer workshop learning into classroom practice, curriculum, and learner support material can (van den Akker 1988):

Provide theoretical background information on the meaning of the change;

Demonstrate the practical meaning of the change;

Provide users with opportunities to experiment with exemplary activities, thereby gaining insight into the consequences of the change; and

Provide concrete resources that can serve as a frame of reference for the intended educational change.

To fulfil their potential, curriculum support material should contain a large amount of specific and concrete guidelines for teachers. Learner support material needs to be of good quality to have the potential to be effective, and they indeed can have positive effects if they are (Chavunduka 2005; Leyendecker 2002c; Mafumiko 2006; Ottevanger 2001; Thijs 1999). However, curriculum support material cannot substitute but only assist in capacity building. The combination of both exemplary material and professional development activities are generally considered to create synergy effects. In the long run, more in-depths and in-service education are of greater potential benefit for improvement of instructional quality (van den Berg 2001).

In some SSA countries, teachers are expected to produce their own learner support material. Teachers appear to have neither the time and capability, nor the technical capacity to produce their own material. Extensively donor funded and supported programs to semi-professionally develop instructional material with selected teachers have not yielded the desired results (for example, SEITT in Zimbabwe; Chavunduka 2005). In one case in South Africa where teachers have managed to produce (and were then willing to share) high quality instructional material, other schools have strongly benefited to the extent that these materials replaced the official ones. In some countries (such as Tanzania), externally initiated and organized in-service programs especially for the sciences produced cost-effective and easy to produce learner-support material enhancing the understanding of abstract scientific concepts (molecule structures, electricity). Across SSA, curriculum materials are 
developed as part of $\mathrm{PhD}$ theses or university based research that, provided the cooperation and questions of copyright, could be shared regionally.

Where materials were delivered and exist at schools, many side observations have shown that they are not always put into full use. In other cases the instructional material delivered has gone missing. In some cases expensive models simply lack the most basic maintenance. The call for more instructional materials, particularly sophisticated ones like computers or expensive vocational models, means calling for additional tasks in maintenance and organization that require additional time. Those who call for more resources are not always prepared to listen to the call for maintenance. The following persisting problems observed in most of visited SSA countries illustrate that instructional materials will not necessarily and automatically achieve its potential for change:

The distribution and availability of the learner support materials to schools;

The management, organization and maintenance of the materials at the school level;

The opportunity for teachers to use the materials at school level; and

The will and capability of teachers to use the materials for pedagogically purposeful instruction.

Solving the problems with existing instructional materials requires professional and institutional development. The development of instructional materials as such puts the challenge on the respective educational systems, and requires the professional capacity and will to do so.

\section{Textbooks}

\section{Potential for Learning}

The issue of textbooks in SSA is double-sided: on the one hand textbooks are of particular importance for instructional support, and considered crucial for the effective implementation of the curriculum (Chisholm 2000). On the other hand, many SSA teachers depend more on textbooks than it is intended by the new understanding of quality teaching. Most SSA teachers follow textbooks to structure and conduct their lessons, because it saves them from much of the work of lesson preparation, sometimes to the extent that the use of the textbook substitutes for adequate lesson planning to the disadvantage of instructional quality. A well-reputed school in Ghana does not accept that teachers enter the classroom with a single textbook to avoid simple textbook reading. Instead the teacher is expected to prepare before and from more than one source, and use his/her preparatory notes for the lesson.

Students may benefit from textbook use to increase literacy, for homework reading, and for projects and assignments. Although adequate quality and availability of textbooks are important for SSA education reforms, they can only achieve their potential if consciously used as part of planned instructional practices. Textbooks alone do not increase the quality of education.

In some SSA countries, "despite more than a quarter century of effort and investment of tens of millions of dollars, African students lack adequate access to textbooks. Where textbooks have been produced, they are not always available to students in sufficient numbers" (World Bank 2002). For Botswana and South Africa it has been reported that the 
money for textbook acquisition was available at schools as well as the textbooks were available with the publisher, but the transaction process was hampered by the work of middlemen for un-specified reasons.

Textbook production and supplying quality textbooks to schools is complicated by the large amounts of money involved, the large economic interests of textbook providers, and the sensitivity of the process to corruption. Issues include: (1) affordability, (2) production, (3) selection, (4) supply, and (5) use and management of textbooks. These are discussed in the next subsections.

\section{Affordability}

Where students are supplied with textbooks, they are either provided free of charge (Botswana), or purchased by parents. Textbook free of charge provision is widely regarded as problematic because of students' attitudes towards free material, and the subsequent damage and loss of used books. Buying textbooks, on the other hand, is out of the financial reach of many parents. Lewin (2004b) claims that poor countries cannot afford books.

In 50 of 89 World Bank financed education projects in 40 SSA countries, governments tried to recover the costs of textbook provision through sales or rental fees. The attempts have failed because of management, failure to allocate funds to compensate for subsidiaries, or because they were too unwieldy or inequitable (World Bank, 2002). To provide a mechanism for equity of access to textbooks, the World Bank suggests that selective assistance for students in need is better than subsidized rental fees or sale prices.

\section{Production}

In present SSA, only a few countries still depend solely on state or parastatal agencies to produce textbooks. Because of experiences with inefficiencies, former support for centralized and state-dominated modes of textbook production is increasingly shifting to private sector initiatives and competition in textbook provision. The move from state to private provision of textbooks is likely to increase the costs since commercial publisher must recover all costs from sales. "Savings from the transition will occur only if overhead and other costs previously incurred in public textbook provision are removed" (World Bank 2002).

The shift to private services in textbook production may include writing, editing, illustration and design, production, and delivery. Presently, multinational publishers provide for the bulk of textbooks in SSA. Increasingly, different political and economic interests call for local African publishers to produce the textbooks. From the curriculum perspective, the decisive argument for the selection of publishers should be based on the quality of textbooks. A positive argument for local publishers may be their ability to provide textbooks in local languages, which could be of particular interest for the primary level.

Independently of the provider, textbook production is a time-consuming process. Chisholm (2000) states that once curriculum policies and guidelines are available, publishers require approximately two years to produce quality textbooks. The textbook report of the World Bank even estimates a three years time span for textbook production. Publishers have requested that they be provided with enough time for the trialing and development of quality material. 


\section{Selection and Quality Assurance}

The quality of textbook production depends firstly on the publisher's capacity, particularly the author's expertise and written communication skills, and secondly the lucidity of the curriculum and guidelines provided by governments. For educational quality, textbooks must fulfil a number of criteria:

Textbooks must be aligned with the curriculum, and include the conceptual changes for learning. Academic and social content, language and length must be appropriate for the students' contexts and age. Texts should be written in short sentences and of readable language. Particularly for the sciences it has been suggested to include exercises and references throughout the book.

While one does not need to reinvent the wheel, in certain areas, instructional material and textbook should not simply be copied from international textbooks, but appropriately developed for the context of the SSA student. Publishers to some extent have already answered to this need. Publishers can be further encouraged to do so, although it seems that the textbook requirements are not always clearly spelled out by SSA educational systems.

Textbooks must be practical for teachers and for teachers' conditions. For teachers in remote areas, textbooks may be the only source of professional development and curriculum support. The level of practicality can be improved by providing additional teacher guides and/or in-service activities. It has been suggested that teachers guide include signaling mechanism for teachers to assess students' learning achievements. In many SSA countries, teacher education formally includes training in the use of textbooks, although the training is not always implemented. In Namibia, as one example for strengthening the practicality of textbooks, publishers, teachers, and committees teachers partner to test drafts of textbooks.

Textbooks must be cost effective. Local publishers cannot compete with international publishers, which in some cases has made local publishers team up with international publishers. The conflict extents into textbook selection.

In SSA countries, the books to be used in individual schools are either prescribed by local boards, or can be chosen from official lists. Where schools have free choice of multiple textbooks, for example, partly in South Africa, the numbers of textbooks available for selection can proliferate. Yet, it is not the number of available textbooks that is important, but the quality. The presently common selection process across SSA for single books or list of books gives the responsibility to ministries (such as in Botswana) or ministerial evaluation committees. The Educational Materials Approval Committee (EMAC) in Tanzania meets occasionally to consider new textbooks and other materials, however, minutes are for the committee only. In general, committee members need to have both knowledge of subject matter and of the curriculum, which may require training provided at the national level (respectively the provincial level if appropriate).

To ensure appropriate selections and effectiveness, textbook selection processes should be transparent, based on clear selection criteria and a set of standards aligned with tender procedures, and the curriculum. Although existing, for some countries it has been said that 
selection panels have not followed the set guidelines. To counter problems with corrupt influences, practices in Senegal require that two subsequent panels approve textbooks.

\section{Supply, Use, and Management}

Ordering books, awarding tenders to suppliers and supplying textbooks, and the provisioning process require close coordination between many different sections and directorates. Many textbooks in SSA do not reach the intended schools, but are damaged, lost in transit, or diverted to other schools or the open market. The capability of the book supply chain, adequate storage space at all levels, and appropriate management and monitoring systems are indispensable for better supply and use of textbooks. When textbooks are sold and delivered through commercial channels, the delivery to rural areas may be problematic.

Where textbooks at schools are available, they are not always put into full use. Many SSA countries have reported that books are sitting virtually unpacked in storerooms at schools for lack of a management and textbook distribution system, or fears of damage. Where schools have received or purchased textbooks and distributed to students, the number of available textbooks have dramatically declined after two or three years only, to the extent that textbooks were insufficient in numbers. Schools may be in need of training and detailed procedures in maintaining textbook stocks. 



\section{Attained Curriculum: Assessment and Assessment Practices in Sub-Saharan Africa}

\section{Assessment, Examination, and the Wider Picture}

Modern curricula in SSA formally aim at learning outcomes like comprehension, application of knowledge, methodological and social competencies, and problem solving. Current assessment and examination practices are limited to the recapitulation of memorized facts. Assessment documents in some SSA countries claim that a wide range of assessment techniques are used to assess the different knowledge, skills and attributes, however, the reality looks remarkably different. In many if not all SSA countries, current assessments are not objective measurements of the intended modern curriculum, because to a large extent they effectively measure only a part of the curriculum content. This is partly a consequence of implementation, and the discussion about implementation in Chapter 8 includes the issue of examination and assessment. In the following sections, this chapter focuses on the specific situation and challenges given for examination and assessment in SSA.

\section{Examinations, Assessment, and the Curriculum}

Examination results in Africa are high stakes. They have been and still are the dominant assessment factor for education in SSA, and students' futures depend significantly on examination success. Examinations are the most popular determinant of access to secondary education, to particularly valued streams of secondary education, to higher education and to the world of work. They hold great significance as a rite of passage, thereby providing incentives and motivation for students to learn. Various commentators on the guaranteed and nearly 100 percent transition rate from primary to secondary education level in Botswana have noted that the lack of examination consequences reduce the motivation of students to actually learn. The Republic of Ghana (2002) straightforwardly 
recommends for the Ghana situation discontinuing wholesale promotion without reference to academic performance.

Assessment and examinations may cripple a curriculum, or they may drive and steer it. Teachers, principals, parents, and politicians judge educational success in terms of results. Teachers and schools themselves often are measured according to the same examination results of their students. O-saki and Ndabili (2003) report on the motivational factor of national examination ranking to the effect that teachers focus mostly on examination success at the expense of general knowledge and understanding. "Teachers teach for examination success" is a commonly repeated phrase all over SSA. What is not assessed is very often left out in the classroom. Assessment and evaluations that only require students to reproduce facts and definitions will inevitably train students for rote learning and memorisation of facts, whatever the curriculum wishes to aim at. If examinations require the answering of some forms of paper-and-pencil tests, teachers will accordingly train their students. On the other hand, assessment and qualifications that only test for methodological and social competencies lack the achievement of clear exit skills, and have proven to lead to an "anything goes" attitude in the classroom.

\section{Examination Results: Junior Secondary Level, and Results of the TIMSS study}

Table 12 depicts overall pass rates in the core subjects of national JSE examinations. Figures in brackets detail the pass rates in the individual grades.

\begin{tabular}{|c|c|c|c|c|}
\hline Subject/Country & Botswana (2004) & Ghana (2003) & Senegal (2005) & Tanzania (2004) \\
\hline $\begin{array}{l}\text { Total number } \\
\text { of candidates }\end{array}$ & $\begin{array}{l}35,533 \text { (failures } \\
\text { grade } \mathrm{G} \text { not } \\
\text { indicated) }\end{array}$ & 278354 & $\begin{array}{l}70,219 \\
\text { Success rate } \\
\text { 2005: } 30.18 \% \\
\text { (2004: } 55.41 \%)\end{array}$ & 62,359 \\
\hline First language & $\begin{array}{l}77.3 \% \\
\text { (A: } 0.6 ; B: 7.2 ; \\
\text { C: } 17.9 ; D: 51.6 \text {; } \\
\text { E: } 22.8 \text { ) }\end{array}$ & $\mathrm{n} / \mathrm{a}$ & $\begin{array}{l}\text { detailed data still } \\
\text { missing }\end{array}$ & $\begin{array}{l}\text { no subject } \\
\text { detailed data } \\
\text { available }\end{array}$ \\
\hline $\begin{array}{l}\text { Second language } \\
\text { (English except } \\
\text { for Senegal) }\end{array}$ & $\begin{array}{l}74.6 \% \\
\text { (A: } 1.4 ; B: 7.8 ; C: 17 \\
\text { D: } 48.4 ; \text { E: } 25.5)\end{array}$ & $58.3 \%$ & & $\begin{array}{l}\text { General pass } \\
\text { rate (failures } \\
\text { grade E) } \\
88.1 \%\end{array}$ \\
\hline Mathematics & $\begin{array}{l}71.3 \% \\
\text { (A: } 4.5 ; B: 6.5 \\
\text { C: } 11.9 ; \text { D: } 48.4 \\
\text { E: } 28.3 \text { ) }\end{array}$ & $59.6 \%$ & & $\begin{array}{l}\text { (A: } 7.2 ; B: 7.3 ; \\
\text { C: } 23.6 ; D: 50 \\
\text { E: } 12)\end{array}$ \\
\hline Science & $\begin{array}{l}68.6 \% \\
\text { (A: } 3.9 ; \text { B: } 8.1 ; \\
\text { C: } 13.4 ; \text { D: } 43.2 \text {; } \\
\text { E: } 31.4)\end{array}$ & $57.1 \%$ & & \\
\hline Social Studies & $\begin{array}{l}71.1 \% \\
\text { (A: } 1.7 ; \text { B: } 8.6 ; \\
\text { C: } 16.9 ; \text { D: } 43.9 \text {; } \\
\text { E: } 28.9 \text { ) }\end{array}$ & $58.9 \%$ & & \\
\hline
\end{tabular}




\section{Figure 7. Selected TIMSS 2003 Results}

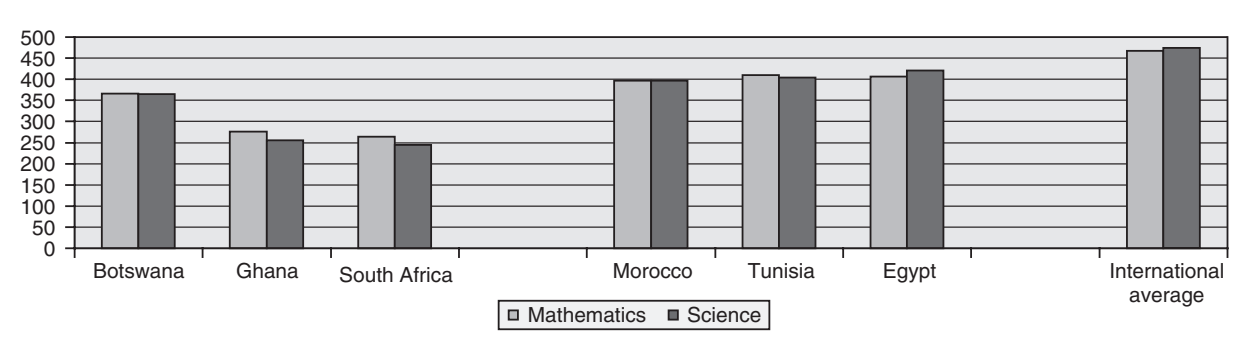

Although the data are not available for all countries, the majority of students pass examinations in the lowest category only. This has already raised concerns in the countries, because the examinations document low achievements in limited items measured (mainly multiple choice, and structured papers). The concerns are even greater when considering learning achievements of higher cognitive skills. The TIMMS 2003 study is an international study on achievements in mathematical and scientific abilities, involving students at the Grade 8 (the junior secondary level in this report), in which three SSA countries (Botswana, Ghana, and South Africa) have participated as part of a total of 46 countries worldwide. TIMMS intended to mainly measure higher cognitive skills. The study results placed the achievements of the three SSA countries in both mathematics and sciences at the very last three places at the bottom of the table. Figure 7 shows the overall scores of the SSA countries. The results of the three participating North African countries are displayed for additional comparison. The column on the right shows the international average in achievements (467 in maths, 474 in science).

Although there are variations within the achievements within the countries, the results show that the three SSA countries scored well below the international average (and this with SSA countries on average allocating more time for mathematics in their timetables as the international average).

To get a more detailed perspective on the students' performance, the Figure 8 describes the results in terms of international benchmarks. The benchmarks are described as:

Advanced international benchmark: corresponding to a scale of 625;

High international benchmark: corresponding to a scale of 550;

Intermediate international benchmarks: corresponding to a scale of 475; and

Low international benchmark: corresponding to a scale of 400.

For mathematics in Ghana and South Africa, 90 percent or more of students did not reach the low international benchmark. Botswana scored considerably better but still remains a far distance from the international average. For sciences, the scores are slightly better for each country, but basically depict a similar picture. Even within the reservations that may exist against TIMMS, the implications of the results are that the overwhelming majority of students do not have a good grasp of knowledge and conceptual understanding of basic mathematical principles, and poor knowledge and weak grasps of scientific concepts and enquiry skills. In terms of the test items used, the TIMSS result showed that students obtained 
Figure 8. TIMSS 2003 international benchmarks for Math and Sciences
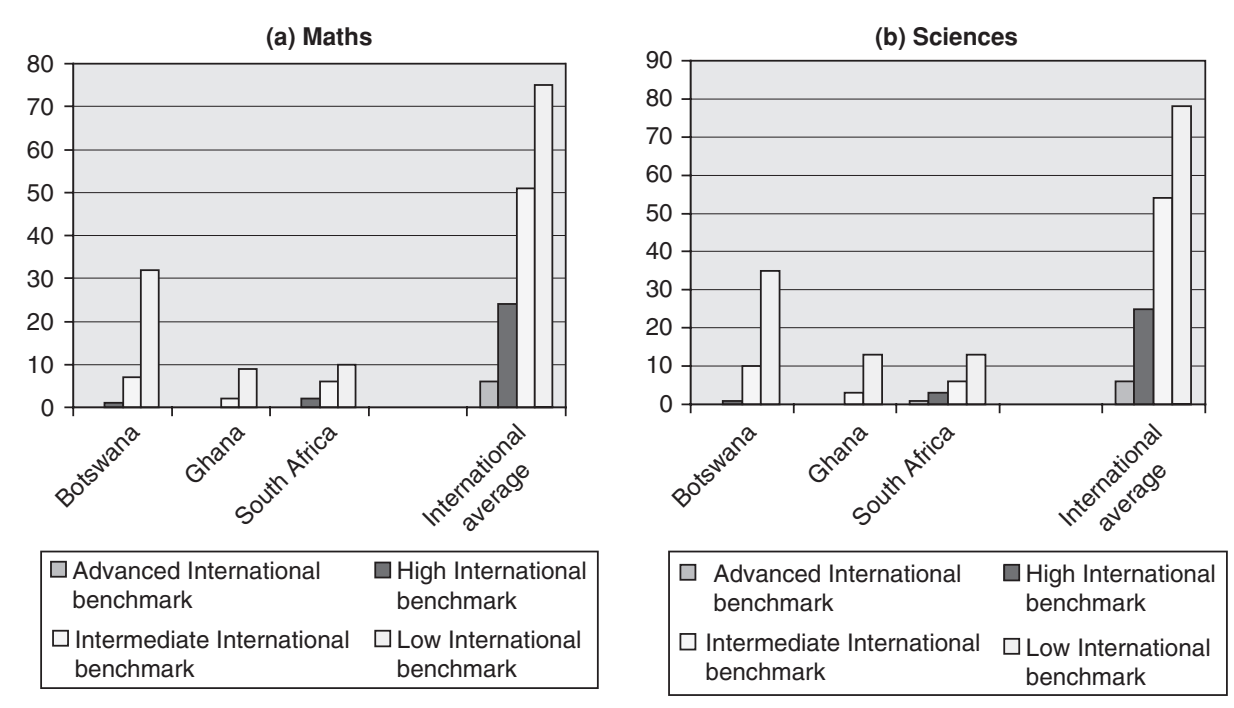

higher responses on multiple-choice items (which include a chance probability for correct answers) as compared to correct responses on constructed response items.

\section{Examination Results Senior Secondary Level}

The curriculum at the SSE level offers different subject combinations across SSA. The examination results presented in Table 13 provide less insight for cross-country comparison.

For a variety of reasons, examination results are limited in their meaningfulness. For example, in Tanzania the pass rates are high, but the University of Dar es Salaam developed their own examination tests because the quality of students are not considered at par with examination results. In Nigeria it is said that SE certificates can be simply bought.

In recognition of the limitations, the overall observation shows examination achievements dominating in the middle and lower range, with examination results in Mathematics and the Sciences lower than in other subjects. In Senegal, the pass rates between public schools, private confessional schools, and private non-confessional schools differ considerably (Public: 55\% [A + B + C = 7.3\%]; Private confessional: 83\% $[\mathrm{A}+\mathrm{B}+\mathrm{C}=13 \%]$; Private non-confessional: $34 \%)$.

\section{Standard Setting and Quality Assurance of Secondary Education Examinations}

Most SAA countries have localized curricula, and localized examinations, or are in the process of localization. Namibia and Botswana have kept ties with the University of Cambridge Examination board to ensure appropriate standard setting in their SE examinations. Ghana and Nigeria conduct their examinations under the auspices of the West African Examination Council (WAEC). South Africa has reestablished a quality assurance 


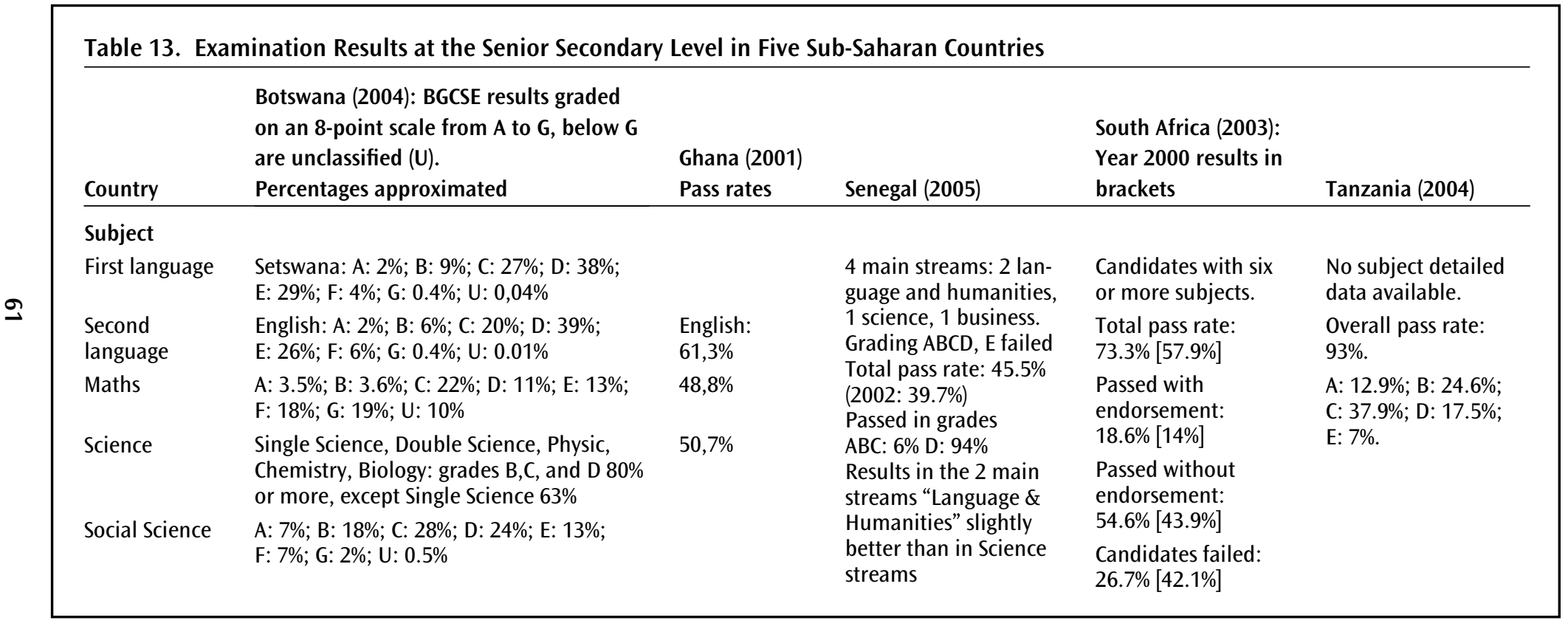


board for secondary education (Umalusi), and in 2005 has compared the standard of its examination questions against Scottish standards because the increases in pass rates in South Africa since 1994 (partly reflected in the year 2000 and year 2003 results in the table) have raised concerns in the country.

Senegal in 2005 has discontinued its oral examination component for the JSE examination (BFEM). After the discontinuation, the examination success rate has dropped from 55 percent of the year before (and similar figures since 1999) to 30 percent. For English as a second foreign language, the oral examination will be reintroduced along a set of assessment and marking criteria for the oral exam.

\section{Alignment Between Curriculum and Assessment}

Assessment and examinations have multiple potentials and consequences for curriculum development and implementation. Particularly the implementation potential of educational reform hinges prominently on the attached assessment and examination practices. A departure from the currently dominating rote learning in African classrooms to the provision of higher skills and competencies requires a departure from current assessment practices. If the implementation of new curricula demands new forms of assessment but the implementation of assessment practices and instruments lags, the curricular changes have little or no chance to make it into the classroom. It is a common observation and result of numerous researches across SSA that the lack of alignment between curriculum intentions and assessment, and the quality of assessment and examinations remains a major obstacle for curriculum implementation at large.

For most countries, alignment between curriculum development and assessment and evaluation requires better alignment at the organizational level. The current discrepancy between examinations and curriculum in SSA points shortcomings in the coordination between the national agencies responsible for curriculum and assessment. A particularly striking example may be the Tanzanian case where the two agencies responsible for curriculum development and examination are divided by the literal wall in between. Yet, 30 years ago these two agencies were a unified and single institution. While organizational and management factors (communication, co-operation, clear demarcation of responsibilities) contribute to the lack of alignment, another major reason for the division and the sealed-off nature of all examination agencies in SSA are questions of reliability of examination results. They are, after all, important quality criterion for examinations, and closely connected to questions of equity and quality. Although the Ghana junior secondary examinations of the year 2002 that were cancelled and repeated nationwide, are a rather extreme example, experiences of widespread examination leakages and other fraudulent examination are commonly reported all over SSA. Therefore, although better alignment between curriculum and assessment are important for better learning, the demands for both reliable and valid examinations require solutions that include the larger educational system and context.

\section{Assessment Items and Examination Practices}

Evaluations and experiences in SSA countries have shown that due to practical problems on the ground the current assessment realities look less promising than the well-meant idea spelled out in curriculum reform. Particularly the adaptation of assessment instruments to 
more learner-centered and competency based education faces the challenges of maintenance of standards (validity), reliability, and practicality. The problem of lack of clear assessment instruments and marking schemes seems to be a persistent one.

Questions about logistics, expansion, lack of professionalism in assessment, quality of examinations, and lack of alignment between assessment and curriculum surround examinations across many other SSA countries. Additional problems with corruption additionally question the accountability and legitimacy of examination results. These already existing challenges in the present examination system magnify the problems of adjusting to the demands for new forms of assessment. The reorganization of examination and assessment arrangements and the implementation of new assessment instruments face a number of crucial challenges in SSA interlinked with technical necessities and systemic requirement. These challenges include:

The definition of standards as part of the curriculum and as accepted levels of performance for assessment, the quality assurance of standards, and the attached question of where to locate quality assurance for standard-setting and standard monitoring, and with which role. In Botswana, a country that is quite open about the flaws in its own education system, the quality of assessment was described as "characterized by low quality test items and inadequacy, i.e. the test items are poorly constructed and not enough tests are given" (Department of Secondary Education 2003).

The need to differentiate conceptually between standard grades and higher grades, and the subsequent expectations of school-leaving requirements as opposed to higher-education entrance requirements, and the attached need to involve tertiary education in the setting of norms and standards.

The inclusion of new forms of assessment for skills not measured in existing assessment practices, and not measurable in common examinations, including the development of appropriate and workable assessment criteria, particularly for continuous assessment (CASS) (see next section).

Improvements in the quality of examination setting, particularly the technical requirement to develop appropriate and accurate examination items, for example, length of papers, appropriate terminology and expression, appropriate types of questions, predictability of questions, and most importantly, appropriate levels of cognitive demand. The inclusion of assessment items measuring higher cognitive thinking needs to avoid the assessment items becoming predictable through repetition of similar examination questions over the years.

Ensuring improvement in the moderating and monitoring the process of setting the question papers, specifically the selection, training and monitoring of examiners and moderators to take greater cognizance of required assessment practices. A research report from the quality assuror in South Africa (Umalusi 2004) states that the present criteria for selection-subject expertise and experience-are no longer sufficient to ensure that the question papers are appropriate tests of candidate knowledge and competence. This sends a strong message across SSA since most if not all African countries select their examiners on exactly these criteria that demands for additional capacity building and professional development of examiners and moderators. 
Awareness about the contributing factor of language proficiency, and accordingly the setting of assessment questions measuring a wide range of learning and not language.

Considerations about the need for adequate statistical moderation of examinations, particularly where CASS forms parts of examinations.

The need for statistical data gathering on examination and assessment, including its use to allow for the provision of information about the achieved levels of curriculum implementation to allow for remedial interventions. The use of ICT is strongly benefiting for this task.

Present examination practices are frequently mentioned to effectively limit the teaching of higher order cognition. To illustrate the point: during data collection the researcher was invited to observe a chemistry lesson in which students were conducting and evaluating experiments with the use of a three-column schemata. During the collegial discussion after the lesson, the teacher and the researcher agreed that the addition of a fourth column into the schemata would allow students not just to conduct the experiment, but to understand the methodology behind it. However, the teacher commented that while he would like to use a fourth column, he felt the need to train the students to the three-column schemata to prepare them for the examinations, because the sheer appearance of a fourth column in the examination paper may very likely mark the complete answer as wrong.

The above list of challenges emphasizes the complex nature of curriculum reform and its interdependency, the need for a holistic approach that includes professional development (in this case of teachers, examination setting, and marking), organization and management (communication, co-operation, clear distribution of responsibilities, selection of examiners, verticalization of hierarchal structures), professional culture, and the need to make the curriculum the centre of reform. The complexity of challenges depicts that they cannot be solved in one step, but requires incremental professional learning of the complete educational system.

\section{Continuous Assessment and Assessment Instruments}

Examinations allow for a limited measurement of certain skills and knowledge only. To move from present examination practices to the inclusion of a wider range of assessment to adjust to the wider range of teaching of skills is an acknowledged need in SSA. The widened assessment practice is generally referred to as continuous assessment (CASS). SSA countries increasingly intend to introduce continuous assessment as part of their assessment or examinations (although it is not implemented in reality). CASS is usually conceptualized to determine the level of students' competencies to serve as a signaling mechanism for the achievement of learning, and to make sure that students integrate and apply knowledge and skills.

In Tanzania and in Ghana, CASS is practiced as the continuous evaluation of subject content covered (norm-referenced tests), its main purpose being to promote students through periodic tests to the next educational level or class. Tanzania has now included a 50 percent CASS (rather continuous testing) in the final examination. Although curricula formally move to the inclusion of practical skills and higher learning, assessment practices still ignore the specified areas of knowledge and skills, and test the memorization of facts 
only. In Tanzania, the examination of practical skills in Physics and Chemistry appear to have for many years revolved around the same problem area, and rather consist of the repetitive conduct of experiments.

CASS in South Africa intends to be used for formative and diagnostic purposes within the classroom. South African CASS intends to be based on tests, classroom interaction, project work, investigations, and assignments. The South African basic education examination consists of 75 percent CASS, and 25 percent so-called Common Task Assessment. Students passing examinations are widely reported to lack basic reading, writing and mathematical skills. The validity of the assessment and the reliability of the subsequent certificate awarded are questioned and are yet to be proven. The inclusion of CASS is often problematic when it comes to grading. CASS marks are usually far above the final examination marks of students indicating that there is a problem. Often, the CASS marks are statistically moderated to fit the final exam.

\section{Summary and Practical Suggestions for Examination and Assessment}

Summarizing the discussion before, assessments and examinations of good quality need to include:

Valid assessment instruments, which actually assess or measure what they claim to assess or measure:

the individual items have to be consistent with the goals or objectives they claim to assess;

the items for each objective are to be representative of the range of items that are possible to develop for that objective; and

the objectives upon which the instruments are based are adequately sampled.

Reliable assessment instrument, which consistently measure what they claim to measure, and in which there is a high degree of confidence in the scores produced.

Practical assessment instruments. For a meaningful use of new assessment instruments teachers need to be induced into the new practices, and in the underlying concepts. In practical terms, the move to criterion-referenced assessment requires the teachers to be versatile with assessment methods. It highlights the need for professional development of the teacher. Since both the induction and the use of the new assessment instruments are more time consuming for teachers, they add up to teachers' workload requiring them to accept the responsibility to apply the more time-consuming assessment instrument meaningfully.

The challenges of assessment and examination particularly for the implementation of refocused curricula are widely acknowledged in SSA. The following practical suggestions for improvement were often shared or provided by practitioners in the field in the various SSA countries:

Examinations should include different levels of cognitive skills for all subjects that may be based on an openly accessible large bank of items that randomly draws questions for examinations. 
Coursework assessment could be used for both summative purposes to generate marks for end-of-year and examination grades, and for formative purposes in providing feedback for teaching and learning.

- Assessment should include skill-based questions for the examinations of sciences, thereby necessitating a continuous practical approach to teaching.

Assessment and examinations should gradually move to the inclusion of continuous assessment (CASS). In SSA, it was often suggested to increasingly include portfolio work to allow for the development of individual thinking. Challenges exist for portfolio work, where teachers and students need files and other stationery.

- The introduction of new assessment procedures should be based on the existing assessment and teaching realities, and follow an incremental approach. New assessment instruments are mandatory to be supported by quality in-service education to enable teachers to practically and meaningfully handle the new instruments.

Quality assurance needs to ensure validity, effectiveness, comparability and accountability of assessment instruments, and the use and application of it. Particularly in view of the inclusion of technical and vocational education into secondary education, this is a particularly daunting task not to be under-estimated.

- Teacher training institutions are to partake in the development of assessment instruments.

Assessment literacy should be included in teacher training.

Assessment and examination should be conducted to provide feedback about institutional effectiveness and systemic efficiency. 


\section{Curriculum Development \\ Processes}

\section{Policy Framework}

\section{Learning from Past Experiences}

In spite of numerous reform attempts and considering the input already made in many SSA countries over often extensive periods of time, the achievements made are below hopes and expectations. One of the major obstacles remains the wide "gap between rhetoric and implementation, between plans and achievements, which became part of the scenario of education reform worldwide" (UNESCO 2006). A meaningful analysis of the persistent gaps in SSA requires looking at the complete picture of curriculum reform and attached processes. The analysis in the following of the holistic curriculum entity of organizational structure, curriculum conception, curriculum development and implementation processes is meant to create awareness about the interdependency of curriculum reform at all organizational levels. The aim of the detailed analysis to follow is to enable future curriculum reform to result in the most positive impact on learning, and development at large.

Two of the main ground-conditions for educational reform are the perception and political agreement of curriculum reform as an ongoing process to be pursued over a prolonged period of time and across election cycles (Fullan, 2001). Political will is the key to curriculum reform (UENSCO, 2006, for literacy). It includes the will to ensure for the credibility of educational programs and aims. The credibility of educational goals and programs at large has been strained in many SSA countries because many past programs and substantial external support, sometimes over decades, have not resulting in much positive impact in the classroom. In many SSA countries, lacking credibility of educational reform significantly contributes to the lack of motivation in educational systems and classrooms that in return limit implementation efforts. 


\section{Complexity, Agreement, and Societal Consent}

Problems with curriculum reform efforts in SSA have been reasonably well-documented. Commonly, the problems to curriculum reform are targeted singly and in isolation. Isolated reform attempts aim at solutions that are frequently sought outside of one individual group of stakeholders; it is others that are expected to change. Yet complex curriculum changes in SSA cannot be solved by any singular group of stakeholders, e.g. policy makers, teachers, or parents. For curriculum reform to become effective hinges on a multitude of interlinked changes from policies, educational system, teachers, and, particularly for reaching equity, parents and community. The complexity and curricula demands for a concerted action that requires societal consent and widespread agreement not just as a moral obligation, but also practical necessity for any reform.

Further, the changes that are likely to really matter and that are required for reform to become effective cannot be mandated by political power. Even when assuming that implementation technicalities are catered for, the departure from traditional teaching-learning approaches in SSA still requires teachers and organizations to change deeply ingrained practices and beliefs. The support of stakeholders is a vital stepping-stone for individuals to understand the importance of their active participation and input in the larger framework of change. To reach this support demands for societal consent. In this respect, widespread agreement is a very first starting point for curriculum reform to become effective; whatever form of communication may be considered appropriate within one country to achieve the broad agreement. Policies are vital for the enabling and guiding the process of societal consent. Policies are pivotal for setting the tone, conditions and framework for reform, for providing support and pressure, and for role modeling.

\section{Scope of Ambitions}

The need for "equity" and "quality" are nationally and internationally was recognized in the Jomtien declaration in 1990. However, it should be cautioned that political expectations should not overburden secondary education, particularly those that seek to redirect the curriculum towards "correcting social and economical ills" (Kliebard 1987). It must be acknowledged that education (or even a curriculum) cannot change society, economies, or on its own produce national development. Vesting such hopes in education are bound to lead to disillusionment, neglect the focus on other societal and economic factors partaking, particularly for economic development, deviate the discussion about the important issues in education, and take the focus off the needs to make educational reforms work. The problem with such admirable social intensions rests in the high level of intensity involved. With policy focusing so intensely on the desired effects of curriculum proposals, both the need for implementation and the constraining realities with respect to curriculum implementation are likely to be overlooked, misjudged, underestimated, or a combination of all.

The starting point for curriculum reform is that education, and getting education right, are important because more and better education to a higher level for all is both a good in itself and can create the conditions for enhanced social and personal development. Schools have the potential and can be given the role to assist in the achievement of wider goals of social justice, equity and development, and also develop the intellectual abilities, critical faculties and social values of school students. 
In spite of the agreement on the quest for quality education and the need of better student, recent curriculum reforms in SSA that directly linked education to other issuessuch as socioeconomic development or societal restructuring - have caused controversies about the benefits of education. In some countries, the disputes were representative of conflicting political interests, or of societal inequities, and limited societal consent.

\section{Focus of Curriculum Reform: Design and Implementation}

The general "problem with policy is not generating it, it is implementation and management" (Lewin 2004a). The gap between rhetoric and implementation is well reflected in educational programs or institutional task descriptions based on sound needs analysis and description of goals and tasks that are often unrealistic and hardly ever implemented effectively. The past orientation of curriculum reform formulation of policies and plans have resulted in different levels of emphasis on the processes attached to curriculum development, and different allocations of time lines. Table 14 provides an overview of the main processes attached to the development of the three curriculum levels, and the relative weight it received from policies in many SSA countries. In some countries, e.g. Namibia after independence, and South Africa during the transition period, curriculum development processes were strongly affected by the particular situations at these times.

Substantial efforts, long-times lines, and considerable funding are awarded to the first four phases (consultancy work, strategy development, identification of needs, donor communication), particularly as compared to implementation processes. The orientation on

Table 14. Curriculum Development Processes and Weights of Importance

\begin{tabular}{|c|c|c|}
\hline $\begin{array}{l}\text { Curriculum } \\
\text { representation }\end{array}$ & Processes attached & $\begin{array}{l}\text { Weights of importance attached } \\
\text { from political perspective }\end{array}$ \\
\hline \multirow[t]{2}{*}{ Intended } & $\begin{array}{l}\text { Consultancy reports writing } \\
\text { and recommendations } \\
\text { Needs identification } \\
\text { Development of policy paper } \\
\text { Strategy paper development }\end{array}$ & $\begin{array}{l}\text { Highly weighed importance, } \\
\text { long time lines }\end{array}$ \\
\hline & Syllabus writing & $\begin{array}{l}\text { High weight of importance, often } \\
\text { very short timelines }\end{array}$ \\
\hline \multirow[t]{4}{*}{ Implementation } & $\begin{array}{l}\text { Communication with donors } \\
\text { for funding } \\
\text { Dissemination of formal } \\
\text { curricula, short in-service } \\
\text { introductions to teachers }\end{array}$ & $\begin{array}{l}\text { High importance } \\
\text { Medium weight of importance, } \\
\text { single events }\end{array}$ \\
\hline & Examination development & Low weight of importance \\
\hline & Long-term teacher development & Low weight of importance \\
\hline & $\begin{array}{l}\text { Development of existing } \\
\text { organization and management }\end{array}$ & Low weight of importance \\
\hline \multirow[t]{2}{*}{ Attained curriculum } & $\begin{array}{l}\text { Quality of learning and } \\
\text { quality of teaching }\end{array}$ & Low weight of importance \\
\hline & Examination results & High weight of importance \\
\hline
\end{tabular}


policy formulation underestimate systemic requirements and resources, neglect the process character of change, and the curriculum-technicalities attached to facilitate the process. Fullan's quotation of an outgoing deputy minister (supposedly in the United States) appropriately illustrates the understanding of curriculum development in SSA: "Well, the hard work is done. We have the policy passed, now all you have to do is implement it." (Fullan 2001). While passing the policy may indeed be hard work, it is only the beginning of the real task of educational change. It is a common problem in SSA and elsewhere to mainly regard the quality of a curriculum as the incorporation of modern and ambitious intentions in plans and formal documents, and to forget about the need to focus on the efforts to make it work. Even the best and most valuable ideas are non-effective if not implemented. The implementation in the classroom determines outcomes, not policy papers. Shifting the strategies and systemic approaches of, in the first line, policies, and, secondly, curriculum development from their present orientation on plans and ambitions to an orientation on implementation will be a first step towards effective curriculum reform. A second step that then will help in creating the supportive starting conditions will be the change of perceptions towards considering curriculum design and curriculum implementation as an intertwined process of curriculum development.

\section{Addressing the Gap Between Plan and Achievement}

Probably the most treacherous misconception about the ideals in a curriculum is the persistent assumption that well-meant ideals spelled out in policy papers are to be considered equal to achievements made in the classroom. While the ideals of the South African curriculum reform attempts are close to the situation described in the policy paper, it would be hard to find many people in South Africa that could be persuaded to believe that the actual and realistic situation in classrooms and the educational system are anywhere close to the description offered in the policy paper. A multitude of evaluations, researches, educationalists' opinions, and scholarly articles clearly tell the opposite story of the claimed changes. Good ideas do not travel on their own into classrooms, and achievements wanted are not necessarily the achievements made.

\section{Less May Be More}

Where in the past the ideal of an educational program has failed, it was exchanged with another new and different ideal. When this new reform program has failed, it was re-placed with yet another program. Depending on political factors and funding, these cycles have been repeated one or many more times. Repetitious cycles of unsuccessful reform increasingly render new reforms problematic because they leave residues of negative reform experiences. Negative perceptions add up if multiple reforms are attempted at one and the same time or are overlapping in time, or if they swamp schools and teachers. Permanent attempt at changes overburden teachers and educational systems and limit the readiness to engage in further reform. In South Africa, for example, the implementation of C2005 and its practical consequences created considerable discontent and dissatisfaction with the new curriculum, yet the major tenor in the country is to better adhere to the now existing curriculum than to undergo the whole process again, with all of its struggles and efforts. 


\section{Curriculum Design and Time Lines}

Although the major contributor to instructional quality are teachers using appropriate teaching and learning approaches, ensuring vertical and horizontal internal consistency within a formal curriculum contributes to quality learning. Providing for internal consistency is a demanding technical task during curriculum design, requiring sufficiently long timelines for completion, and competent staff knowledgeable in both curriculum and specific subject content. Political pressure and mandated implementation often set tight deadlines for the development tasks, and often neglect the need for capacity building in this area. Most time lines for curriculum design processes analyzed in this report were by far too short. Some politically set time frames for curriculum design, development, and implementation are simply not feasible. After negative experiences with first curriculum attempts, Botswana has allowed for a five years period to gradually design, include and formatively evaluate revised syllabi and assessment structures in their general education curriculum. After similar experiences with short time lines in its first attempt with C2005, South Africa for its revised curriculum has allowed for a much longer time for design and gradual implementation. Senegal from the onset plans for a five-year period to develop, pilot and introduce their new secondary curricula.

\section{Curriculum Development and Systemic Alignment}

Most SSA countries have established specially designated institutions (either parastatal, or ministerial departments) officially tasked with curriculum development. In general, the roles of the curriculum development units are narrowly defined, and restricted to syllabus writing. The process of implementation and the planning for it is commonly detached from curriculum development.

Widening perceptions and understanding about curricula while designating responsibilities will increase the soundness of the approach for curriculum development. In some SSA countries, the roles and tasks of curriculum units (and related institutions) are formally well defined, and even formally cater for some of the suggestions offered in this report (some kind of development research, development of in-service education programs). However, between task formulation and productivity there is a gap for a number of related reasons ranging from lacks of responsibilities given, capacity, accountability, and professional culture. The partaking of these institutions in professional development will support the overall alignment and effectiveness of the educational.

In present realities in SSA, curriculum development occurs mainly isolated from related institutions. A major cause of problems at the systemic level appears to be the lack of focus on the curriculum itself at both the national and regional education departments. The conclusion from Chisholm reporting on South African curriculum innovations 'that this is partly because curriculum is not seen yet as the core business of departments of education' is valid for other countries as well. "Seeing curriculum as the core business would mean centralizing the coordination and resourcing of curriculum ... in order to ensure that the overall coordination of provision, allocation and distribution of resources is taken far more seriously than it has been" (Chisholm 2000). A driving unit at the systemic level to coordinate and oversee the development of the curriculum and its implementation can be expected to coordinate efforts, and to support inter-institutional mediation. 
The existing organizational structures and management often restrict continuous and coherent curriculum development (including flexible implementation). Systemic alignment, particularly during implementation, is important. The alignment with assessment and examination has been discussed already, of further importance are alignments with teacher development and in-service education, inspectorate, and pre-service. Better communication among institution related to curriculum development, and clear definitions of responsibilities will support the cooperation amongst institutions, and may contribute to the development of professional cultures. The horizontal communication of most SSA educational systems is partly limited because of the strong vertical communication structures that results in a bottleneck effect. The adaptation of existing communication structures are, together with clear distributions of responsibilities and accountability, important components in the development of the organizational culture, and towards professional capacity building.

Experiences and observations gained during this study strongly indicate that countries with working ICT supporting the organization and management structure of educational ministries and educational institutions, are by far better prepared and equipped to deal with the complexity and technicalities of curriculum reform.

\section{Considerations About Curriculum Implementation}

\section{Hi-fidelity Implementation}

Top-down approaches are frequently identified as a major cause for implementation failures in SSA and elsewhere because they neglect the importance of the context, but rather emphasize the importance of the planned curriculum to be faithfully brought into the classroom. Present literature uses the technical term for faithful enactment of a planned curriculum, fidelity of implementation (FOI) (Ruiz-Primo 2005). FOI at one hand may describe the strict adherence to prescribed program components (group work, learnercentered education, and so forth), on the other hand it may refer to the causal levels of a program's mechanism that must be preserved to achieve the intended program outcome (better teaching to achieve better learning). It is widely agreed that adaptations in implementation are necessary for a program to be successful. The question is then not about exclusive fidelity and adherence to program components, and neither about amorphous adaptation ("anything goes"). The question is about the degree of FOI required to implement the essential meaning of a curriculum while allowing for on-site adaptation. It goes together with other questions about program delivery, for example, amount of program content received by participants, quality of program delivery, participants' responsiveness, and program differentiation (Ruiz-Primo 2005). Intending to implement the essential meanings within curriculum reform entails the need for a clear conceptualization and focus of implementation, such as the departure from traditional learning and teaching approaches, followed by appropriate strategies to practicably bring the meaning into use. Strategies and implementation attempts in SSA face a dichotomous challenge. On one hand, curriculum reform in SSA will fail if the intended increases in instructional quality are not achieved. Yet the complex changes that are needed to improve on instructional 
Figure 9. FoI Interacting with Program and Context Characteristics

\begin{tabular}{|c|c|c|}
\hline \multirow{6}{*}{ 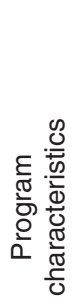 } & \multicolumn{2}{|c|}{ Degree of fidelity of implementation } \\
\hline & \multicolumn{2}{|c|}{$\longleftrightarrow$} \\
\hline & Time consuming & Time efficient \\
\hline & Additional materials required & Self-contained materials \\
\hline & Low quality learning support materials & High quality learning support materials \\
\hline & Low quality in-service & High quality in-service \\
\hline$\stackrel{\mathscr{U}}{.0}$ & Little ownership & High ownership \\
\hline 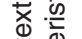 & Less theoretical agreement & More theoretical agreement \\
\hline$\stackrel{0}{0}$ & Less satisfied teachers & More satisfied teachers \\
\hline ن & Program perceived as ineffective & Program perceived as effective \\
\hline$\frac{\mathrm{c}}{0}$ & Infrequent supervision & Frequent supervision \\
\hline
\end{tabular}

Source: Adapted from Ruiz-Primo 2005.

quality cannot simply be mandated into the classroom. On the other hand, some kind of FOI must be maintained to preserve the "causal mechanism of a curriculum" (better teaching) to result in better learning. To devise strategies, Figure 9 depicts the degree of FOI interacting with program and context characteristics.

With respect to causes and requirements, the table can be read both ways. The more complex and time consuming a curriculum, e.g. as improvements in teaching, the more need to allow for adaptation. The better the quality of the materials and in-service, the better the potential for implementing its essential elements. The more ownership ("sharing of the meaning") teachers have of the curriculum, and/or the more their understanding and agreement, the more satisfied teachers are, the more supervision and feedback, the better the implementation potential.

To allow for more ownership, understanding and agreement from the early stages of curriculum development, present curriculum trends in Europe favour more decentralized approaches to curriculum development. According to Hopkins (2005), centrally imposed curricula can go a long way towards educational reform, but the extra 10 percent may require decentralization. For the SSA context it is important to acknowledge that the model of decentralized approaches is based on the existence of high levels of systemic capacity and quality teaching. These conditions do not yet exist on a wide scale in SSA. To shift to more decentralization in curriculum development in SSA will only be an option when the hopeful achievement of curriculum reform are realized. Figure 10 illustrates the shift.

The central approach to curriculum and implementation is of particular value for the contemporary SSA context, where there seems to be no alternative to the central provision of support and resources to eliminate existing differences in education. Problems with regional implementation of C2005 in South Africa underline the need for centralized provision, implementation, and capacity building in SSA at large (and the meaning of "regional implementation" is still a long way from the meaning of decentralization of curricula development). 
Figure 10. Shift from Centralization and Specification To Decentralization

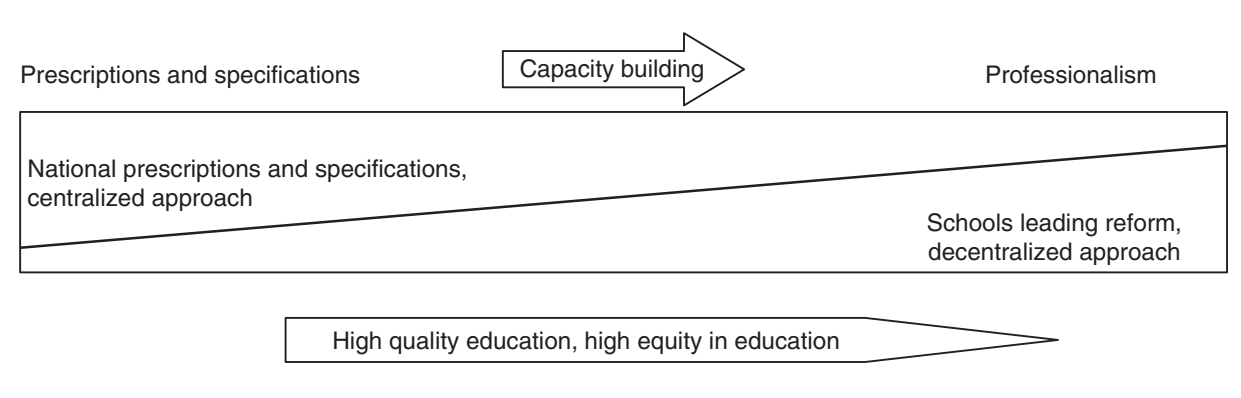

Source: Adapted from Hopkins 2005.

\section{Implementation Realities}

The high-fidelity perspective assuming that a planned curriculum will and can readily be accepted by teachers misconceives implementation facts and experiences. It neglects that there are as many interpretations of any curriculum as there are teachers and other stakeholders (Fullan 2001), that the intended change requires substantial adaptations in teachers' practices, attitudes, and understanding, and, particularly for SSA, that there are considerably different starting points of teacher capacity and local context. Although the centralized approach to implementation fits the present SSA context better than the decentralized one, the high-fidelity model does not fit the heterogeneous and diverse SSA classroom. Attempting change through the prescription of methodologies limits the understanding of the purpose why these methodologies should be applied in the first place, and neglects the importance of connectivity with local context.

The conceptual implementation challenge is to share the meaning of a curriculum, while providing enough support and specifications for teachers to ensure practical application. Instead of mandated prescription, procedural specifications should focus on essential elements of proven vulnerability during implementation, individualized support, and on sharing the meaning behind the change. Without procedural content, for example, instructional methodologies connected to content knowledge, or continuous assessment, the curriculum lacks the clarity for handling. As recent curriculum attempts in SSA have shown, the conversion of principles, abstract curricula, ideas and objectives, or increased knowledge into relevant classroom behavior is a demanding task, and one of the main barriers to educational change (Doyle and Ponder 1977). For a new curriculum to be introduced in classrooms, it must qualify as practical, and must contain instrumental content. Designing curriculum proposals into concrete and practical classroom procedures that depict classroom contingencies will increase understanding, and orient teachers towards their tasks.

\section{Practical Issues of Adaptation and Implementation in SSA}

The orientation of curriculum reform on policies and ambitions and less on detailed implementation leads to political expectations of high fidelity that contradict the need for flexible implementation. The existing strongly hierarchical structure of educational systems adds up to 
a conceptual misunderstanding of implementation processes as 'teacher proof' high fidelity. For example, Rogan notes for the South African C2005 that in the admirable intention to transform the inheritance of apartheid "there is already a disturbing trend to act as if Curriculum 2005 cannot even be debated, let alone be modified" (Rogan 2000). Marsh and Willis (1999) suggest "that in reality all planned curricula become modified during the process of implementation and that such modifications to suit the specific and changing situations faced by the teachers who enact them is essential if the curricula are to have the greatest possible benefits for students." The gist of adaptive proposals is not to dilute curricula until they are watered down, but to transport the meaning of a curriculum rather than only symbolic procedures into the classroom. Regarding curriculum reforms in present SSA, the improvement of learning and the subsequent introduction of more active teaching and learning approaches must be at the heart of development efforts. Basing the actual process of change on the various contexts and individual capacities incorporating aspects of instrumentality and balance has far more potential to actually get important curriculum characteristics transported into the classroom.

Adaptive implementation models put the teachers-and the teachers' capacities to understand and enact the change - at the center of educational development. It demands quality and flexible in-service education to provide for the necessary support and professional development. Both capacity building at the teacher level and the wider systemic level hinge on the professionalization of education. Ultimately, the implementation of modern curricula and improvement in instructional quality are questions of professional cultures.

Understanding curriculum meaning could be as simple as considering the use of language. In South Africa, for example, teachers' understanding was significantly limited by the use of the terminology in which the curriculum was framed. The new language was considered obscure and imprecise and had an exclusionary effect to those who were expected to enact the change. The need and the nature of changes should be communicated in common and understandable languages, avoiding the proliferation of new terminologies and the substitution of ordinary words like teacher, subject, and textbook.

\section{The Need for Formative Evaluation of a Curriculum}

The shift to adaptive and implementation oriented approaches in curriculum development includes the need for feed back about the nature of implementation obstacles, and their consequences for implementation. Implementation obstacles occur naturally as part of the implementation process. They have the unwelcome tendency to accumulate and to aggravate the obstacles into problems in the process of further implementation that more often have amounted to rendering numerous implementation exercises ineffective. Detecting implementation obstacles through iterative cycles of formative evaluations at various stages of the implementation allow for remedial interventions before the problems become overwhelming. Formative evaluation focuses on questions of implementation practicality, and informs developers about omission of critical curriculum characteristics or the implementation of inappropriate techniques. It helps in determining what works best for whom. Formative evaluations need to include the interrelation of implementation with educational functions serving in key areas, e.g. assessment and examination, teacher orientation and training, learning support materials, and regional capacities.

Defining sound quality criteria for formative evaluation will provide the framework to detect implementation obstacles (for example, the criteria applied in this report (relevance, 
consistency, practicality, effectiveness, sustainability). To obtain a firm and precise base for revision decisions, data-gathering methods such as direct and structured classroom observations, teacher interviews, and students' tests are more informative than questionnaires that may seem cost-efficient but often provide reactive outcomes with a lack of precision (van den Akker 1994).

The potential and use of formative evaluation to support and adapt a curriculum during the implementation process is underestimated in SSA, and therefore hardly ever used. Where evaluations are included in curriculum planning or in the organizational framework, they often lack the resources to be conducted. Where evaluations are conducted, they are understood as anything between the need to formally review curriculum documents, or the occasional visit of the school inspectorate.

Yet evaluation processes and evaluation results per se cannot effect change, they uncover problematic implementation obstacles. Evaluation results need to be judged wisely and translated into decisive actions in key areas (Chisholm 2000). Organizational structures, systemic capacity, the coordination among participating institutions, communication structures and management need to allow for the feedback of evaluation results into the implementation process. There is often the danger, when Departments of Education commission or conduct their own evaluation, of supporting a whitewash or uncritical evaluation. Formative evaluations require a degree of confidence of politicians and bureaucrats that is often lacking because of insecurity in the professional culture, or perhaps it is the ability not to take criticism too personally that is missing. Formative evaluation implies the need for criticism to be constructive and un-personal. The receptivity of the Department of Education seems to be the key. Being open to criticism requires a degree of confidence in the underlying project or capacity to be able to deal with the criticism.

\section{Development Research in Support of Curriculum Development}

Iterative formative evaluation as advocated before is a strong tool for fine-tuning curriculum during implementation. Taking the idea of formative evaluations one step further leads to more advanced models for implementation oriented curriculum development. Development research has been successfully employed as a support in curriculum development, also in SSA (Thijs 1996; Ottevanger 2001; Mafumiko 2006). Development research serves three purposes that are of particular interest for curriculum development and implementation in SSA (van den Akker 2004):

Optimization of the development of prototypical products including provision of empirical evidence for their effectiveness;

Generation of methodological directions for the design and evaluation of such products; and

Contributing to the body of knowledge, and thereby increasing systemic capacity.

The highly relevant foundational tenets of development research for curriculum development are:

Local relevance (tailoring educational innovations for different contexts and cultures);

Collaboration, authenticity (basing working knowledge on target setting); and

Continuous analysis (regular analysis of risks and benefits). 
Development research is based on broadly applicable design procedures, and aims at optimizing curriculum interventions and design principles. Its main focus is on the practicality of the interventions for the users in real world settings, and applies methods like iterative development with formative evaluations in users' settings. The following points characterize development research:

Use of intensive formative evaluations during prototyping;

Priority of information richness and efficiency;

Variety of techniques and instruments;

Triangulation of data;

Incremental shift of quality criteria in the course of the implementation from relevance to consistency, to practicality, and to effectiveness; and

Limited generalization potential.

\section{Up-scaling}

Up-scaling is a common model for externally assisted educational reform funding for a pilot that is expected eventually to expand its reach, that is, scale up from the pilot setting to the entire education system. "The track record in this regard in Africa is very poor" (Samoff 2005). One of the major problems concerns the replication model from one setting in many diverse settings that rarely succeeds because the insight, energies and dedication are dissipated, often to the effect that even the initial pilot collapses. "What must be reproduced is not the form and detail of an effective pilot but rather the conditions for innovation, mobilization of human and other resources, and local ownership that enabled the pilot to succeed" (Samoff 2005). To be able to reproduce (or produce) potentially effective conditions requires the creation of a manageable and sustainable organization.

In recent years, a number of efforts for large-scale curriculum changes have been attempted in Africa (Namibia, South Africa), or are about to be attempted (Ghana, Senegal, Tanzania, Uganda). Evaluations of such attempts indicated a number of common findings. While the aims of the intended curriculum changes were and still are noble and valid in themselves, the changes have hardly made it into the classroom; or are very likely not to make it. The following list indicates the main factors for the shortcomings, many of them known by now:

The intended change was too far-reaching to be bridged in one step. The changes intended were above the capacity of the educational systems and its teachers. In addition, some of the expectations on the curriculum change were too ambitious, and from the onset it was very questionable if the curriculum could deliver to the expectations at all.

Not enough time was provided and not enough technical expertise was used in the initial design of the curriculum. Some curricula were merely a compilation of individual syllabi, in some curricula the vertical coherence (between subjects) or horizontal coherence (between levels) within the curriculum were lacking.

The meaning and requirement of the change lacked clarity due to shortcomings in curriculum design because of rushed implementation.

Instructional materials were lacking; the organizational structure throughout the system was not sufficient to distribute and manage the instructional materials. 
Professional development infrastructure and organization was not adequate enough; support personnel were lacking.

Staff working in the professional development structures lacked knowledge and understanding of the change. This proved to be a particular hindrance for large-scale in-service organized in a cascade model, but to a lesser extent to cluster models as well.

The in-service education programs were too short in duration. 


\section{Capacity Building}

\section{The Need for Capacity Building in Sub-Saharan Africa}

Capacity building at all levels of the education system is central for better classroom instruction, for a better examination system, for developmental support and monitoring, and for better management of educational structures in the existing system. It is central to any improvement of existing teaching-learning approaches, and central for any improvement to build on. Table 15 briefly sums up the potential and target of capacity building for curriculum reform in SSA as already referred to at various points in this report, and its link to the educational system.

\section{Teacher Professional Development}

Educational changes depend on the teachers' capacity and motivation to adapt to and enact changes. It is generally assumed that there is a strong and direct relationship between professional development and improvements in student learning (Guskey 2000). This applies particularly to SSA where the learning of concepts, problem solving, and personal skills only to a limited extent depends on formal curriculum restructuring, but first and foremost on the teaching practices happening in the classroom.

The change in teacher practices is expected to result in the improved student learning outcomes. The influence of professional development on students is accomplished principally through its direct effect on teacher knowledge and practices (Guskey 2000). Although the quality of professional development does not directly or exclusively affect improvements in students' learning (other factors include resources, internal consistency, external consistency), high-quality professional development is an important and necessary 
Table 15. Potential Influence of Capacity Building on Individual
and System Development

\begin{tabular}{|c|c|c|}
\hline Potential & Target & Systemic link \\
\hline $\begin{array}{l}\text { Teaching practices, content } \\
\text { knowledge, methodologies }\end{array}$ & Teachers & $\begin{array}{l}\text { In-service, professional } \\
\text { development programs }\end{array}$ \\
\hline In-service education & In-service staff, multiplicand & Organization and management \\
\hline Professional development & $\begin{array}{l}\text { Ministerial departments, } \\
\text { University staff }\end{array}$ & $\begin{array}{l}\text { Organization and management, } \\
\text { teacher organizations }\end{array}$ \\
\hline $\begin{array}{l}\text { Effectiveness, } \\
\text { communication, } \\
\text { co-operation }\end{array}$ & $\begin{array}{l}\text { Schools, departments, } \\
\text { Ministry }\end{array}$ & $\begin{array}{l}\text { Organization and management, } \\
\text { professional culture }\end{array}$ \\
\hline Instructional material & Developers & Organization and distribution \\
\hline Textbooks & $\begin{array}{l}\text { Development, selection, } \\
\text { distribution, stock keeping }\end{array}$ & $\begin{array}{l}\text { Educational system, evaluation } \\
\text { committees, school organization }\end{array}$ \\
\hline $\begin{array}{l}\text { Curriculum design } \\
\text { (internal consistency) }\end{array}$ & $\begin{array}{l}\text { Curriculum developers, } \\
\text { subject specialists }\end{array}$ & $\begin{array}{l}\text { Distribution of responsibility, } \\
\text { accountability }\end{array}$ \\
\hline $\begin{array}{l}\text { Curriculum development } \\
\text { (external consistency) }\end{array}$ & $\begin{array}{l}\text { Curriculum developers, } \\
\text { educational system }\end{array}$ & $\begin{array}{l}\text { Co-operation and organization } \\
\text { (steering) }\end{array}$ \\
\hline $\begin{array}{l}\text { Implementation planning, } \\
\text { formative evaluation }\end{array}$ & $\begin{array}{l}\text { Educational system, } \\
\text { evaluators, curriculum } \\
\text { developers }\end{array}$ & $\begin{array}{l}\text { Co-operation and communication } \\
\text { among departments, in-service }\end{array}$ \\
\hline $\begin{array}{l}\text { Validity of assessment, } \\
\text { standard setting }\end{array}$ & Items constructors & $\begin{array}{l}\text { Co-operation between assess- } \\
\text { ment, curriculum development } \\
\text { and pre-service }\end{array}$ \\
\hline Reliability of assessment & Examiners (teachers) & Co-operation \\
\hline Quality assurance & Examiners, policy advisers & $\begin{array}{l}\text { Systemic assessment, cooperation, } \\
\text { political framework }\end{array}$ \\
\hline $\begin{array}{l}\text { Communication and } \\
\text { co-operation }\end{array}$ & $\begin{array}{l}\text { Educational system at all } \\
\text { levels, responsibilities } \\
\text { and accountability }\end{array}$ & $\begin{array}{l}\text { Shift from vertical to horizontal } \\
\text { organizational structures, sharing } \\
\text { of responsibilities, accountability } \\
\text { at all levels }\end{array}$ \\
\hline $\begin{array}{l}\text { Transparency and } \\
\text { accountability }\end{array}$ & $\begin{array}{l}\text { Educational system at } \\
\text { all levels }\end{array}$ & Political framework, role models \\
\hline
\end{tabular}

prerequisite for any change from traditional teaching-learning approaches. Better professional development (including in-service activities) is central to the improvement of the instructional quality in SSA, where at present the professional development initiatives are rather haphazard, short-term initiatives, and mainly donor funded. Better provision and quality of professional development and in-service education are a central priority for curriculum reform in SSA focusing on quality learning.

\section{Content of Professional Development}

Professional development activities usually focus on teachers' knowledge, skills, methodologies, more or deeper understanding, but also to different types of expertise and 
responsibilities. For instance, in SSA, professional development efforts focusing on improving on teachers' knowledge and practices are directed toward:

Providing teachers with increased disciplinary content knowledge.

Familiarizing teachers with the purpose and practice of a wider range of instructional practices.

Familiarizing teachers with the theory and practice of the interlinked application of subject content and methodologies (called pedagogical content knowledge). It is this combination of disciplinary content knowledge and appropriate instructional methodologies that are required for quality teaching and learning.

- Providing teachers with theory and practice of alternative forms of assessment knowledge. Specified in-service activities needs to ensure that all teachers are versatile with the purpose and application of assessment practices that are introduced as part of any curriculum reform.

Raising the professional culture.

Regarding teaching-learning approaches, Rogan (2001) distinguishes between four different starting points or levels for classroom interaction and assessment. The constructed levels attempt to express how the vaguely defined notions of "good practice" may look like in classrooms. The levels were originally developed by Rogan (2001) for the sciences, and have been adapted for this report for all subjects. The construct is meant to provide an overview of actual classroom and assessment practices, and to illustrate the adding-up of the more sophisticated levels onto lower ones. It may well be that classrooms in SSA do not display any of the practices, or that a teacher may well be at different levels of classroom and assessment practices. It is important to note that higher levels are inclusive of the lower ones. Higher levels do not discard the practices of the level before, but incorporate it. The levels increasingly move away from the teacher-centered classrooms to active learning approaches until level 4 comes close to the high ambitions of learner-centered education. It must be stressed that level 4 teaching in its pure form is the desirable exception hardly to be found in classrooms anywhere in the world.

Few people can move from a professional development experience directly into implementation with success. Fitting new practices and techniques to unique on-the-job conditions is an uneven process that requires time and extra efforts, especially when beginning. Teachers across SSA are a highly heterogeneous group with very different educational backgrounds and experiences, resulting in different levels of capacities. The capacity of the teacher mainly depends on:

The teachers' own learning experiences;

The teacher education received;

The in-service and educational support delivered;

The availability of, and the knowledge to use learner support material;

The school culture and professional environment at schools;

Teachers' accepting responsibilities for the quality of the classroom instruction; 
Table 16. Levels of Classroom Interaction, and Assessment

\begin{tabular}{|c|c|c|}
\hline Level & Classroom interaction & Assessment \\
\hline 1 & $\begin{array}{l}\text { Teacher: presents content in a well organized, } \\
\text { correct and well-sequenced manner, based } \\
\text { on a well-designed lesson plan. Provides } \\
\text { adequate notes. Uses textbooks effectively. } \\
\text { Engages learners with questions. } \\
\text { Student: stay attentive and engaged. } \\
\text { Respond to and initiate questions. }\end{array}$ & $\begin{array}{l}\text { Written tests are given that cover } \\
\text { topics adequately. While most } \\
\text { questions are of the recall type, } \\
\text { some require higher order thinking. } \\
\text { Tests are marked and returned } \\
\text { promptly. }\end{array}$ \\
\hline 2 & $\begin{array}{l}\text { Teacher: Textbooks are used along with } \\
\text { other resources. Engages students with } \\
\text { questions that encourage in depth thinking. } \\
\text { Student: Use additional (to text book) sources } \\
\text { of information in compiling notes. Engage in } \\
\text { meaningful group work. On own initiative, } \\
\text { offer a contribution to the lesson. }\end{array}$ & $\begin{array}{l}\text { Written tests include at least } 50 \% \text { of } \\
\text { questions that require comprehen- } \\
\text { sion, application and analysis. } \\
\text { Where applicable, some questions } \\
\text { are based on practical work. }\end{array}$ \\
\hline 3 & $\begin{array}{l}\text { Teacher: probes students' prior knowledge } \\
\text { and learning. Structures learning activities } \\
\text { along the lines of relevant knowledge, } \\
\text { knowledge construction, and problem } \\
\text { solving techniques. } \\
\text { Student: Engage in minds-on learning } \\
\text { activities. Makes own notes on the concepts } \\
\text { learned from doing these activities. }\end{array}$ & $\begin{array}{l}\text { Written tests include questions } \\
\text { based on seen or unseen 'guided } \\
\text { discovery' type activities. Assessment } \\
\text { is based on more than written } \\
\text { tests. Other forms of assessment } \\
\text { might include reports on activities } \\
\text { undertaken, project work, reports } \\
\text { on extra reading assignments. }\end{array}$ \\
\hline 4 & $\begin{array}{l}\text { Student: take major responsibility for their } \\
\text { own learning; partake in the planning } \\
\text { and assessment of their own learning. } \\
\text { Undertake long-term projects (if possible } \\
\text { community-based). } \\
\text { Teachers: facilitates students as they design } \\
\text { and undertake long-term investigations and } \\
\text { projects. Assists students to weigh up the } \\
\text { merits of different theories and knowledge. }\end{array}$ & $\begin{array}{l}\text { Performances on open investigations } \\
\text { are included in the final assessment. } \\
\text { Students create portfolios to represent } \\
\text { their best work. }\end{array}$ \\
\hline
\end{tabular}

Source: Adapted from Rogan 2001.

The professional attitudes towards teaching; and

Teachers' personal motivations.

Instead of focusing on a high and ambitious ideal (such as level 4) for teachers to be reached immediately, implementation and in-service need to adapt and build upon the real and existing starting points of teacher capacities. In-service training will be more effective if it acknowledges the different starting points and needs thus making the changes possible for teachers.

\section{Implementing In-service Education}

In present and past professional development activities aimed at supporting teachers implementing curriculum reforms in SSA, are mainly organized along a cascade or cluster 
model. Although these implementation activities occur in different settings and contexts, some overall observations are valid for all:

Educational systems (districts, schools, teachers) are not adequately prepared for the implementation process, in most cases and most likely because the planning for implementation and in-service education was not regarded as an integral part of curriculum development.

In-service education is either non-existent or provided as short-term crash courses only. Where existing, the activities are often under-funded, the duration of training was too short, and the quality of it was problematic. The cascade system of implementing in-service education as is often used in SSA countries has proven to be inadequate.

Financial, physical and human capacity in the system were not adequately existing. Local and institutional capacity (staffing, leadership, management, planning, administration, management) was not sufficiently available and prepared for the task of implementing an effective in-service education system.

The existence of functioning and well-equipped professional development structures is a prerequisite for implementation. However, its existence does not guarantee a successful implementation. Two other factors are of importance: first, implementation is a process and obstacles will naturally occur in the process and adaptations will be required. Second, teachers need to be motivated and ready to engage with new ideas and put them into practice, and willing enough to put in the extra effort required.

\section{Professional Development and Context Constraints}

While the capacity building of teachers is of particular interest for educational change, it depends on a number of other variables that are influenced by administrative organization and management. Professional development of the complete educational system depends on the development of both the individual and his/her environment. Professionalization in education needs to extend into all ranks of the complete educational system (principals, in-service providers, pre-service, and management and organization). Administrators typically do not directly influence students' learning. However, their knowledge and practices influence students via the interaction with teachers (in-service, inspections), and by modeling high standards of professional behavior (Guskey 2000). Curriculum developers to apply the technicalities in curriculum development and implementation need to know about it. Quality in-service education requires quality in-service personnel, requiring professional development of staff. Administrators and organization to handle and organize complex organizations and quality educational issues effectively need to raise current levels of management and organization.

Botswana in its Vision 2016 (Republic of Botswana 1997) states that all organizations must improve its work ethics and productivity. "Good governance and management are the bases of improved efficiency and effectiveness given the limited resource envelope" (Bitamazire, quoted in World Bank 2003). For the attempted changes to be accomplished, it will be one of the tasks of policies and educational management alike to facilitate higher levels of professionalism in education, and to develop the professional culture in schools 
and educational institutions. The educational system and with it any curriculum reform benefits greatly from professional ethos and role models.

\section{Other Factors Influencing Implementation Education Reforms}

\section{Pressure and Support}

Particularly for implementation efforts, guidance, direction, and support with pressure are crucial when adaptations are being made (Fullan 2001). Regardless of how much advanced planning or preparations take place in an effort to establish readiness, it is when professionals actually implement the new ideas or practices that they have the most specific problems and doubts. At this time, support coupled with pressure is vital for continuation. Support allows those engaged in the difficult process of implementation to tolerate the anxiety of occasional failures. Pressure is often necessary to initiate change among those whose self-impetus for change is not great (Fullan 2001). It is important to note, as observed in South Africa (Chisholm 2000) and other SSA countries, that the quality of the support that goes with pressure is critical for the success. Insufficient support that does not enable and prepare teachers to implement cannot result in the changes necessary, no matter how much pressure is exerted.

Accountability is a form of pressure particularly relevant for the SSA context. Declining working time, erosion of teaching time, unprepared and undedicated teaching are just a few of common problems impacting on the quality of education that cannot be solved through curriculum reform, but are partly related to the lack of accountability. It is important to distinguish between the demands for accountability for job standards, and professional standards. Both sets of standards impact on the quality of teaching, although job standards are rather the basics, on which the professional standards build-up. However, the two have different degrees of impact on the quality of teaching, are based on different conceptual foundations, and therefore have different measurements and connecting points for reinforcement. While job standards (coming to work and attending work for which one is paid) are general work attitudes that can and should be reinforced through common contract requirements, professional standards are less measurable. Professional standards require both positive attitudes and knowledge, are less measurable, and are reinforced by consent rather than by contract.

Accountability embodies relations of power, and schools with most incoherent internal accountability systems are least likely to be able to respond to external accountability requirements (Ball 2004). Chisholm and others (2004) following this arguments suggest that even as accountability requirements may intensify work, schools will vary enormously in how they respond to them - and those targeted as most in need of improvement through the accountability mechanisms are least likely to be able to respond to them. Increasing responsiveness of schools speaks again for the development of the professional school culture.

\section{Change and Motivation}

The provision of in-service education is fundamental but one thing. Teachers' participation in in-service activities, and their readiness to put the change into practice are two very different things. Departing from trditional but familiar teaching-learning approaches in which teachers are confident demands from most teachers in present SSA considerable transformation in personal perceptions and attitudes to understand and implement the 
educational change. Professional, pastoral, and probably administrative duties increase the demands, quantity and intensity of teachers' workload:

Teachers need to deal with heightened expectations, changed roles, and adapted organization for new forms of classroom interaction. They need to understand the meaning of the change, know about diverse methodologies, and increase personal content knowledge.

Quality education needs to start with lesson preparations, requiring the acceptance that working hours of a teacher are not equal to contact time.

New assessment requires knowledge about purpose and handling of the new assessment instruments, but it takes time to apply the instruments in class.

New forms of accountability intensify and increase workloads. The amount and nature of paperwork attached to educational reform can add up to the work load, and increase the perceived work pressure, particularly if the reform is coupled with additional extensive managerial tasks (such as with OBE in South Africa).

Teachers' readiness to invest time and efforts positively correlates with motivation. While the motivational levels of teachers differ considerably within and across SSA countries, on average it must be regarded as low. In reality, working hours are often reduced to the number of contact periods (if at all). Without preparations for lessons, instructional processes are reduced to common, un-demanding outdated methodologies. Occasional easy-to-mark tests are more time saving than complex CASS. Avoiding homework assignment and homework marking saves time. Classes may be doubled-up, some are not attended at all. While these may be worst-cases scenarios certainly not applying to all schools, they are manifold mentioned and observed across SSA. Work attitudes, work ethics, levels of determination, and levels of motivation within the educational system are rarely congruent to the requirements of the educational tasks at hand. Low levels of school cultures do not allow for achievement of high levels of learning outcomes. Apparently, the sense of importance of the educational changes that is reflected in formal educational policies and educational programs is not shared by the majority of teachers, and other parts of the educational system. Therefore it is important, as discussed before, that the goals of educational reform are discussed and negotiated with the aim of reaching maximum levels of agreement within the educational system.

The reasons concerning the low levels of motivations of teachers are complex. Across SSA, the social reputation of the teaching profession has dropped over the last years, and has lost much of the respect it used to have. Particularly in urban centres, the authority of teachers and with it the levels of discipline are declining, and teachers do not always know how to cope with it in the light of traditional relations between young and the old. What is more, teachers feel insecure with the scope of changes required, partly because the implementation models applied require teachers to jump from their current practices and selfunderstanding to a level that is beyond the scope of most if not everyone.

One further reason for the low levels of motivation can be related to the limited buying power of teacher salaries. While SSA teachers are well paid when calculated as a multiple of the respective Gross Domestic Product (GDP), they are amongst the worst paid educators in the world in absolute terms (Govender, 2004), quite likely because the GDP does not reflect the total output of economies. In reality, the absolute buying power of teacher salaries 
is low. In Tanzania, like in other countries, many teachers respond by escaping to a variety of measures like taking up second jobs or businesses to secure their living, which obviously restricts time and energy for teaching and teaching preparations. In Senegal, as another example, most teachers employed at public schools teach at private schools as well.

Probably with the exception of the few middle-income countries in SSA, the low teacher salaries conflict with the political goal of education declared to drive economic development, of which teachers perceive to not participate. Lack of transparency and the wide skepticism about the inefficient and not transparent use of resources do not support calls for increased work ethics. All of the afore mentioned confirm the benefits of politically sound and credible approaches to reform, and the value of role modeling from the top.

Anamuah-Mensah (2002) and many others suggest improving on the current situation and conditions attached to teaching. Improvements for teachers' conditions may increase the motivation of teachers and make them more receptive to calls of professionalization and accountability. It also may change the current perceptions of teaching as a last-chance profession, and may attract the better secondary school leavers into teaching. Yet, it should be cautioned that only offering comparatively high teacher salaries, as Botswana and Namibia have done, without implementing other changes will not on its own increase levels of motivation, or instructional quality.

\section{Job Standards and Professional Standards}

The professionalization of the complete educational sector is crucial and pivotal for any educational development. Yet, the majority of African teachers regard teaching not as a profession but as a job. In view of the focus of this report it is necessary to make the clear distinction between the material side of teaching (the job-side), and the ethical side of teaching (the profession).

A job may be defined as a full-time occupation for payment, or to make a living. In contrast, a profession may be defined as 'any occupation which demands of its practitioner a prolonged and specialized intellectual and exclusive knowledge and training for the acquisition of special skills and attitude necessary for their particular type of service in the community as well as a recognized association for welfare, both of its members and the public it serves' (Aubrey 1998).

Higher demands for adherence to job standards and accountability (the "job" side of teaching) increases the occupational culture:

Attendance of work and classes, teaching of the allocated contact periods.

Timely attendance of work, particularly for teachers for contact periods.

Acceptance of increased responsibilities when accepting higher posts of higher levels.

Focus on the work for which payment is received during working hour. Numerous casual observations in many countries and places have revealed that particularly the new technologies (cell phones, but internet as well) allow individuals at work in parallel to attend to other or even private businesses exceeding reasonable levels of time and distraction.

Job standards are stepping stones for higher professional standards and ethos that are indispensable for education at large, and for any educational reform attempts in Africa. 
They importantly influence human resource development, particularly in education. Teachers' professional ethos is likely to profit from professional quality criteria. The definition of professional quality criteria and professional ethics could be a step towards understanding teaching as a profession. Some SSA countries already have defined professional standards and ethos as part of a comprehensive approach to enhance the delivery and management for secondary schools, e.g. Zambia (World Bank 2003). Developing and defining professional criteria are best be left to teachers, teacher representations, and other stakeholders. Policies must be prepared that any discussion on work ethos will give teachers room to air a number of grievances and raise a number of critical points about conditions of service, and the system at large.

\section{School Culture}

The term "school culture" is a "soft criteria" not as easy to be determined as other school-based criteria, say, buildings, textbooks, or tables. The influence of school cultures on educational quality is visible for everyone visiting schools and undisputed in its importance (de Feiter and others 1995; Guskey 2000; Rogan 2001). The quality of school leadership is particularly relevant for the way in which conditions are determined at school. The structures and policies within schools and the relative stability and support for teachers (the school culture) have a major effect on teachers' willingness to implement new curricula. It determines the responsiveness to external accountability; schools least aligned internally are least able to respond to external accountability requirements. School cultures, in turn, depend on the larger educational and professional culture in a country.

Table 17 on school culture development has been developed from Rogan (2001). It distinguishes between the school management, and the school ecology. De Feiter and others (1995) use the term "school climate" instead of "school ecology."

Schools differ within each SSA country. Individual schools may display practices of different levels. Some schools may not even be on level 1. Higher levels are incorporative of lower ones. Institutional support and demands for accountability will enable schools to make small but important changes.

\section{External Assistance}

Examining external assistance requires putting the focus on the different levels (supra, macro, meso, micro) of the educational system.

At the supra level (policies), external assistance may provide for the important funding necessary to build and upgrade facilities, to provide for resources, and to support programs. However, the emphasis of many donors on the material side may obstruct the view of the many other requirements for successful implementation of educational reforms.

At the macro and meso level (the systemic level), external assistance in capacity building over a prolonged period of time has on a number of occasions supported the establishment of important educational functions. To name just a few examples: quality assurance in institutionalized TVET in Botswana, pre-service structures at a teacher training college in Tanzania, teacher upgrading structures and programs in Namibia. Some of these external assistances contributed to the organizational and professional development of individuals and the institutions.

At the micro level (schools and teachers), external assistance in professional development in many cases proved to be particularly effective especially when experienced educators 


\section{Table 17. Levels of School Management and School Ecology}

\begin{tabular}{ll} 
Level & School management \\
\hline 1 & $\begin{array}{l}\text { A timetable, class list and other routines } \\
\text { are in evidence. The presence of the } \\
\text { principal is felt in the school at least half } \\
\text { of the time. Staff meetings are held } \\
\text { regularly. }\end{array}$ \\
$2 \quad \begin{array}{l}\text { Principal is present at school most of the } \\
\text { time and in regular contact with staff. }\end{array}$ \\
Timetable is properly implemented. \\
Valuable extra-curricular activities are \\
offered to students. They are organized in \\
such a way that they rarely interfere with \\
scheduled classes. Teachers and students \\
who shirk their duties or display deviant \\
behavior are held accountable.
\end{tabular}

3 Schools create structures that focus student time and energy on learning and achievement.Principal takes strong leadership role, is very visible during school hours. Teachers play an active role in school management.

School ecology (school climate)

School functions i.e. teaching and learning occurs most of the time, albeit erratically. The school is secure and access denied to unauthorized personnel.

Teachers and administration share the emphasis on learning and achievement. Management, teachers and students to a limited extent share responsibility for making the school and learning function. A School Governing Body is in existence. The school functions all the time, teaching and learning always takes place as scheduled. Parents actively support students. Basic alignment between teachers, schools, and parents. Teachers are supported and enabled to professional development.

Teachers and administration have high expectations on students' achievement, and on their own performance. Everyone in the school is committed to making it work. Parents play an active role in supporting students, and the school in general. Expectations about purpose of schools, and goals are shared among school and school community.

$4 \quad$ Visionary and participatory leadership.

Shared vision. The school plans for, supports and monitors change. Collaboration of all stakeholders is encouraged and practiced.

and teachers could share their knowledge of contextualized and activity-based teaching, with other teachers.

\section{Pre-service Teacher Education}

Student-teachers who are about to enter the teaching profession have exposed to mainly traditional teaching and learning approaches as students themselves. This seems to apply to teacher educators (University lecturers) as well. In spite of new ideas, teacher education, probably tertiary education at large, to a large extent rather replicates the traditional methodology of secondary classrooms, and in itself is still very much based on the delivery of definitions and the memorization of facts. The inclusion of more appropriate methodologies for teacher training, not just at the theoretical level, provides teacher students with personal and practical knowledge valuable for practical application in the classroom. The shift to active learning methodologies into classrooms 
begins with teacher educators, and requires that professional development includes preservice teacher education programs. The implications for teacher education providers are to re-orientate their own as well as future secondary school teachers to new teaching patterns. Many of the challenges teachers face with the implementation of more learnercentered curricula (for example, change of roles, insecurity with the meaning and requirements of the change, lack of motivation, substantial increase in work load) exist at the lecturer level as well.

Teacher education programs are expected to provide newly qualified teachers with new skills to work in a more learning-focused, critical and problem solving environment to shift from the rote and transmission-oriented learning approach. This in itself is a sizeable task for teacher education that is not easy to fulfill. It bears the risk that providers might focus only on teaching methods, and ignore the need to provide teachers with the content knowledge they also require (Muller 2004).

In SSA, the perception of teaching practices (student internships) as substantial components for the completion of teacher education is increasingly accepted and realized. Commonly, teaching practices are best staggered throughout the years. The monitoring and mentoring of periods of teaching practice are important for the quality of the practice. University based mentoring and monitoring has proven to be expensive, and is often limited by practical problems like lack of transportation, or lecturers being committed to other duties. Alternatively, school-based local mentoring by experienced teachers may provide the additional impetus for teacher training. The quality of the school-based mentoring depends on availability of experienced teachers, their appropriate selection, the setting of standards, and adequate professional development for mentors. Mentors need to be appropriately rewarded, although the incentives do not necessarily need to be material. In some SSA countries (such as Ghana), the mentorship is certified, and mentors are understood as associated teachers to a university. University based action research projects probably in co-operation with mentors (or other teachers) can be valuable parts of teacher education while strengthening the university-mentor relationship, and supporting professional development at large. However, the building up of a quality mentor system is a demanding task likely to suffer from common implementation problems.

\section{Lack of Appeal of Teacher Education and Teacher Profession}

A major challenge for teacher education is the perception of teacher education as the least attractive tertiary education and university level program. In present SSA, young people avoid becoming teachers. Consequently, teacher education programs attract the weakest students entering higher education, i.e. students who cannot be admitted to medicine, engineering, and other more attractive options (Ottevanger and others 2004). In reality, teaching for the majority of teachers is more of an occupational substitution for those who do not find entry into other occupations. In South Africa, the access to teacher education is often used as a transition stage to the more sought after tertiary education studies as soon as opportunities occur. Other teachers see teaching as a stepping-stone to more desirable occupations, and many teachers actively seek alternatives to the classroom.

The chronically depriving societal attraction of the teaching profession needs to be addressed by policy makers. The status is low for mainly three reasons: the salary structure, low entry requirements and examination standards, and the lack of career prospects. The 
report offers some general suggestions for improvements, which however need to be adapted to suit the specific country context:

Setting of minimum entry standards and review of criteria for recruitment;

Offering grants or bursaries and other appropriate incentive schemes for student teachers to attract the better school leavers;

- Guaranteeing employment at the end of teacher education, although this means to balance supply and demand;

Basing rewards on performance, although this is a very problematic issue; and

Developing a career and professional development framework, noting that current career options mostly take teachers out of the classrooms rather than keeping them there better prepared and more motivated. 


\section{Conclusions and Recommendations}

\section{Reform Potential and Focal Points}

Against the background of the goals of Equity, Access and Quality in education, two major ambitions drive contemporary curriculum reform attempts in SSA:

Better and more appropriate, relevant student' learning; and

Expanding and restructuring of secondary education, also to include TVET.

Curriculum reform has the potential to fully respond to the aim for better learning, and to partly respond to the restructuring of SE. Reform can increase curriculum quality mainly in the following areas:

The formal curriculum: the design of the form and content of the written curriculum frameworks and materials.

The implemented curriculum: the curriculum development and implementation processes, and the curriculum enacted in the classroom. The implemented curriculum, particularly the improvement of the quality of the instructional process ("teaching"), is the most important factor for achieving better learning.

The restructuring of secondary education to change its traditional routing - from entry to academic tertiary education to more technical and vocational education-demands the extension, unification, and integration of TVET. The task for more and better TVET involves in many countries the establishment or re-establishment of the complete sector. To limit an already enormous task, it is recommended to base the change on existing TVET contexts. The selection of the model for differentiation and integration of TVET 
should be based on realistic and practical considerations. The theoretical appeal of highly integrative integration frameworks (such as the NQF in South Africa and other countries) is not matched by realistic outcomes, and the numerous practical problems originating from it.

To realize its reform potential, changes need to extend into the context and framework in which the curriculum operates. The focal points for curriculum reform for most countries in SSA are:

The complexity of curriculum reform, and the uniqueness of each reform attempt; Curriculum reform as the central part of educational reform, including the need to gain consent and agreement from society and the educational field for and on the reform;

The importance of the implementation process, and the technical process of curriculum design and development;

The need for capacity building and professional development at all levels, but especially in support of teachers implementing the reforms in their classrooms; and The need to further develop organization and management of institutions in education, alongside and in interaction with curriculum reform.

\section{Complexity of Curriculum Reform}

Curriculum reforms in SSA require comprehensive approaches directed at the complexity of the educational system at large. It requires the acknowledgement of past obstacles and current challenges to reform, as well as the challenges additionally created by the reforms.

Human and physical resources, perceptions, experiences with past reforms and current school and classroom practices determine the limits of what educational systems can absorb in terms of development. Many high political ambitions have implications that are beyond current context and conditions. It therefore makes sense to have realistic ambitions and scope of curriculum reform as these may increase the potential for successful implementation. Sometimes, Less could actually be More. It is recommended that curriculum reform and strategies be based on the realities on the ground and much less on.

The resources (structures, instructional materials, textbooks, but also number of staff and their qualifications) available at schools to a large extent determine the learning conditions, and therefore the learning potential. Disadvantaged schools carry higher burdens. However, it is the active or passive quality of school cultures that are equally determining for learning. Many schools inside and outside of SSA show that:

Actively managed schools can alleviate disadvantages and make a difference (although a minimum level of resources is an elementary prerequisite);

Advantaged schools gain little with passive school cultures; and

Advantaged schools with active school cultures have the greatest benefit by far for students' learning. 
It is recommended that physical resources be provided on a poorest-schools-first basis, to equalize conditions and to enable quality learning, while focusing on development of teacher capacity and school cultures.

\section{Curriculum Reform and Wider Educational Reform}

Coordination of Efforts. Implementation of curricula depends on improved coordination of development efforts with a focus on curriculum. The strong hierarchical structures in education $\mathrm{n}$ some SSA countries limit the communication between organizations so needed to tackle the complex tasks of curriculum development. It is recommended to increase the efficiency, clearly define institutional responsibilities, and provide for more and better cooperation and communication with and across existing institutions and departments. Site observations in SSA have shown that those organizations with wellworking ICT facilities are better prepared to respond to the management requirements of complex reforms.

Internal Curriculum Consistency. Internal curriculum consistency increases the scope of learning and learning potential. Three areas are of particular interest for contemporary curriculum reform in SSA:

Learning achievements at the primary level provide a strong base for learning at the secondary level; or in reverse, failures will extend into the secondary level and accumulate. Ensuring exit skills at the end of an educational cycle is vital for continuation in education (either academic or vocational), and suggests to design down the curriculum from higher levels to lower ones.

The issue of proficiency in the instructional language at the secondary education is a major obstacle to learning for most students in SSA. It deserves high attention and remedial interventions that need to include, mainly for Anglophone countries, the instructional language proficiency of teachers. Present approaches to instructional languages and bi-lingualism suggest the use of mother tongue instruction during the first years of primary education to provide for basic literacy skills, after which there is a transition to learning and using the second language as a medium of instruction.

Building learning potential on prior learning and across educational levels requires the spiral and age-relevant build-up of related subject matter across syllabi. It is recommended that curriculum designers communicate and cooperate across educational levels.

Socio-Political Influences. The more technical component of implementation cannot function without acknowledgement of its socio-political influence. Many factors determining curriculum reform are fluid variables depending on the societal context, influencing the societal context, and being influenced by the societal context. Not all of these variables can be completely influenced by curriculum designers.

Accountability. Ultimately, better learning and teaching depends on increased accountability at all levels of the educational and the political system. At the classroom 
level, a distinction needs to be made between the job side of teaching, and the professional side of it. Increasing accountability in classrooms cannot be achieved through pressure only, teachers also need to be supported and acknowledged.

\section{The Importance of the Implementation Process, and the Technicalities of Curriculum Design}

Implementation Perspective. Current curriculum reforms and larger educational reforms, of which they are part of, focus to a large extent on ambitions and on the "intended" part of the curriculum. "What" shall be achieved, and "what" must be done is clearly spelled out in policies and documents. Often even the specifications ("how") are detailed and backed up by literature and worldwide experiences. Yet, the actual and resulting accomplishments made in reality differ widely from initial intentions. This is largely because of the lack of a focus on implementation of the reforms. It is recommended that curriculum is developed using an implementation perspective. The adage should be "think big, start small."

Development Research in Support of Curriculum Development. There are good experiences with curriculum development exercises that have embraced research as part of the development process. Development research typically consists of: (1) an analysis of stateof-the-art knowledge from the literature and of examples from similar contexts; (2) development of prototypes of the curriculum; (3) iterative process of design and formative evaluation; and (4) a summative evaluation to gauge effectiveness of the curriculum in terms of achieving learning objectives. During development research typically moves its focus from validity about the intended curriculum (how does the new curriculum compare to international curricula) to issues of practicality (how feasible is it for teachers to implement the new curriculum in the classroom without changing their usual teaching practice too much) to measuring effectiveness (how well do students achieve the learning objectives of the new curriculum).

Exemplary Teacher Support Materials. Quality teacher (and student) support materials have a strong potential for implementation. It is suggested that professional developers together with experienced teachers produce such support materials for teachers to facilitate the complex forms of modern pedagogy. In several countries in SSA, exemplary materials have been developed as part of research guiding the development of the new curriculum. SSA regional cooperation may successfully share developed materials, or share the efforts for their development.

\section{The Need for Capacity Development at All Levels}

Teacher knowledge and practices are the primary factors affecting the improved students' learning outcomes. The change in instructional processes depends on teachers' professional development, which is assumed to have a direct positive effect on teachers' knowledge and practices (Guskey 2000). Technical sound curriculum design (such as internal consistency), implementation-oriented curriculum development, consistency of curricula with assessment and examinations, and the interaction between all factors further 
influence instructional practices. The quality of co-operation between educational functions (curriculum development, assessment, in-service, evaluation) affects the feasibility and quality of educational reform. Professional developments in all sections of the educational system support the technical and managerial capacity of the educational system at large, and will increase the potential of curriculum reform.

Teacher Professional Development. Changing teachers' classroom practices does not work by replacement, but by incremental change over sustained periods of time supported by coaching activities of peers, heads of department and external agencies. Teachers' current beliefs and practices cannot simply be substituted but they can be build-upon towards better instructional quality and better fitting methodologies. Teacher professional development is key to more successful curriculum implementation and better student learning.

Job and Professional Standards. Professionalization cannot be mandated, but requires organizational learning and incremental change. Modeling the change is of high value for learning. Adherence to, first, job standards, and secondly professional standards, strongly contribute to professionalization. It is recommended to promote and model high levels of accountability for job standards. It is further recommended to facilitate the definition of professional standards by teachers or teacher organizations.

Capacity Building for Staff of Curriculum Development Units and Examination Agencies. Besides professional development programs for teachers, similar programs for other relevant staff in the education system would be hugely beneficial to efforts of curriculum reform. Such development programs are often attached to national curriculum development activities on an ad hoc basis. There are also examples in SSA where this happens in a structured way. For instance, at the University of Dar es Salaam there is a two year professional MEd program to train staff of ministries, curriculum development units and examination agencies.

External Support to Implementation. Many Western countries have decades of experience with active learning approaches. Over the years, and across SSA, small to mediumscale professional development activities tapping these experiences have shown to make a positive difference for classroom instruction in SSA. Provided that appropriate requirements are met, external experience can contribute to capacity building and professional development in SSA. 



\section{References}

Abelmann, C., R. Elmore, and others. 1999. When accountability knocks will anyone answer? Consortium for Policy Research. University of Pennsylvania.

van den Akker, J. 1988. “The teacher as learner in curriculum implementation.” Journal of Curriculum Studies 20(1):47-55.

_ 1994. "Designing innovations from an implementation perspective." In T. Husén and T. Postlethwaite, eds., The international encyclopedia of education. Oxford: Pergamon Press.

_ 1999. "Principles and methods of development research." In J. van den Akker, R. Branch, K. Gustafson, N. Nieven, and T. Plomp, eds., Design approaches and tools in education and training. Dordrecht: Kluwer Academic Publishers.

Akubue, A. 1988. "Professionalisation of Teaching in Nigeria: Fact or fiction." Education today (1):15-17.

Ampiah, J., K. Akyeampong, and M. Leliveld. 2002. "SMICT study: Ghana Country Paper.” Amsterdam: Vrije Universiteit Amsterdam.

Arends, R. 1994. Learning to Teach. McGraw Hill.

Athumani, A. 2003. Analysis of the Vocational Education Sub-Sector. The Post-Primary Education and Training Study; Synthesis of Consultant's Report. Tanzania Ministry of Science, Technology and Higher Education and the World Bank. Draft.

Ball, J., ed. 2004. The Routledge Falmer reader in sociology of education. London: Routledge Falmer.

Benavot, A. 2004. "Studies on instructional time.” Background paper for EFA Global Monitoring Report 2005 through the UNESCO International Bureau of Education, Geneva.

Benson, C. 2004. "The importance of mother tongue-based schooling for educational quality." Background paper for EFA Global Monitoring Report 2005 through the UNESCO International Bureau of Education, Geneva.

Berman, P., and M. McLaughlin. 1977. Federal programs supporting educational change: Vol 7. Factors affecting implementation and continuation. Santa Monica, CA: Rand Corporation.

van den Berg, E. 2001. "Impact of in-service education in elementary science: Participants revisited a year later." Journal of Science Teacher Education 12:29-45.

Botswana Department of Secondary Education. 2003. Summary of Inspection Findings for the 2003 Inspection Year. Gaborone: Department of Secondary Education.

Bregman, Jacob. 2005. "Secondary Education in Africa (SEIA) and its potential contribution to economic growth: issues related to the provision, quality and relevance of Africa's secondary education." Paper presented at the UNESCO Seminar on Secondary Education in Africa: "What Secondary Education for Sub-Saharan Africa?", Addis Ababa, Ethiopia, November 2005.

Bregman, Jacob, and Karen Bryner. 2003. "Quality of Secondary Education in Africa." Paper presented at the biennial meeting Association for the Development of Education in 
Africa (ADEA), Mauritius, December 3-6. Available at http://www.adeanet.org/ biennial2003/papers/7A_Bregman_ENG.pdf

http://www.worldbank.org/afr/seia/docs_conf_0604.html

Bregmann, J., and G. Simonnet. 2004. "What's next? Coping with Successful Primary Education For All." In P. Govender and S. Grudz, eds., Back to the Blackboard; Looking Beyond Universal Primary Education in Africa. The South African Institute of International Affairs. Brock-Utne, B., and H. Hollmarsdottir. 2004. "Language policies and practices in Tanzania and South Africa: problems and challenges." International Journal of Educational Development 24:67-83.

Chavunduka, K. 2006. Improving science education in Zimbabwe: the role of resource teachers in professional development. Doctoral thesis. Enschede: University of Twente.

Chisholm, L. 2000. Review of the Curriculum 2005. October 2004 at www.pwv.gov.za.

- 2005a. "Diffusion of the national qualification framework and outcome-based education in Southern and Eastern Africa." Paper presented at SACHES conference, Dar es Salaam, Tanzania, September 15-19.

- 2005b. "The politics of curriculum review and revision in South Africa in regional context." Compare 35(1):79-100. Routledge.

Chisholm, L., U. Hoadley, and M. wa Kivulu. 2005. Educator Workload in South Africa. Report prepared for the Education Labour Council. Pretoria: Child, Youth and Family Development, Human Science Research Council.

Coppard, D. 2002. "INSET of Secondary School Science and Mathematics Teachers: Experiences of the SESS Project in Tanzania." In K. O-saki, K. Hosea, and W. Ottevanger, eds., Reforming science and mathematics education in Sub-Saharan Africa. Dar es Salaam: TEAMS project.

Cotton, C. 2001. "Educational time factors." Northwest Regional Educational Laboratory. Accessed February 2006 at www.nwrel.org/scpd/sirs/4/cu8.

Cox, C. 2004. "Organizing Curriculum Reform in Secondary Education: Clues from Latin America." Discussion paper for the 2nd Regional Education in Africa Conference, Dakar, June 6-9, 2004.

De Feiter, L., H. Vonk, and J. van den Akker. 1995. Towards more effective science teacher development in Southern Africa. Amsterdam: VU University Press.

Dieng, P. 2002. "SMICT Study: Senegal country profile.” Amsterdam: Vrije Universiteit.

Dlamini, B., F. Coenders, and R. Stronkhorst. 1995. "Improvement of the effectiveness of the in-service for mathematics and science teachers in Swaziland." Paper presented at the conference on Improving Science and Mathematics in Southern Africa, Windhoek, Namibia.

Doll, R. 1996. Curriculum improvement: Decision making and process. Needham Heights: Allyn \& Bacon.

Doyle, W., and G. Ponder. 1977. “The practical ethic and teacher decision-making.” Interchange 8(3):1-12.

Fullan, M. 2001. The New Meaning of Educational Change. New York: Teachers College Press.

Fullan, M., and M. Miles. 1992. "Getting reform right: What works and doesn't." Phi Delta Kappan 73(10):744-52.

Fuller, B., and P. Clarke. 1994. "Raising school effects while ignoring culture? Local conditions and the influence of classrooms, tools, rules and pedagogy." Review of Educational Research 64(1):119-57. 
Geckler, P. 2000. Impacts of Basic Education Reform in Independent Namibia. Doctoral thesis. Copenhagen: University of Copenhagen.

Gill, I., A. Dar, and F. Fluitman. 2000. Vocational Education and Training Reform. Washington, D.C.: The World Bank.

Govender, P. 2004. “The Tragedy of Education in Africa.” In P. Govender and S. Grudz, eds., Back to the Blackboard: Looking Beyond Universal Primary Education in Africa. The South African Institute of International Affairs.

Guskey, T.R. 1995. Result-Oriented Professional Development: In Search of an Optimal Mix of Effective Practices. North Central Regional Educational Laboratory: info@ncrel.org.

- 2000. Evaluating Professional Development. Thousand Oaks, CA: Corwin Press.

Guskey, T.R., and D. Sparks. 1996. "Exploring the relationship between staff development and improvements in students' learning." Journal of Staff Development 17(4):73-76.

Hopkins, D. 2005. "Leadership for curriculum improvement-going deeper." Presentation at SLO international symposium, Leiden, The Netherlands, December 2005.

Howie, S. 2002. "English Language proficiency and its effects on mathematics achievements in secondary schools in South Africa." In K. O-saki, K. Hosea, and W. Ottevanger, eds., Reforming science and mathematics education in Sub-Saharan Africa. Dar es Salaam: TEAMS project.

Human Sciences Research Council. 2006. A review of the curriculum documents for English second language learning in Grades 1-3 in twelve African countries. Pretoria, South Africa: Human Sciences Research Council.

Jansen, J. 1999. "Setting the Scene: Historiographies of Curriculum policy in South Africa." In J. Jansen and P. Christie, eds., Changing Curriculum: Studies on Outcomes-Based Education in South Africa. Cape Town: Creda Communications.

Ki-Zerbo, J. 1977. "Culture, education and development in Africa." FESTAC colloquium on black civilization and education colloquium procedures, Vol 1. Lagos: Center for Black and African Arts and Civilization.

Kliebard, H. 1987. The struggle for the American curriculum 1893-1958. New York: Routledge.

Koosimile, A. 2005. “Teachers' experiences with an adapted IGCSE physics syllabus in Botswana." International Journal of Educational Development 25:209-19.

Lauglo, John. 2004. Vocationalized Secondary Education Revisited. In J. Lauglo and R. Maclean, eds., Vocationalisation of secondary education revisited. Dordrecht: Springer.

Lewin, K. 2000. Linking Science Education to Labour Markets: Issues and Strategies. World Bank Human Development Network; Secondary Education Series. Washington, D.C.: The World Bank.

Lewin, K. 2004a. "Beyond Primary Education for All: Planning and Financing Secondary Education in Africa (SEIA)." Paper presented at the SEIA donor conference Amsterdam, October.

Lewin, K. 2004b. "Planning and Financing Secondary Education in Africa." In P. Govender and S. Grudz, eds., Back to the Blackboard; Looking Beyond Universal Primary Education in Africa. Johannisburg: The South African Institute of International Affairs.

Leyendecker, R. 2002a. Female Education in Mathematics and Science (FEMSA) in Uganda. Accessed October 2004 at www.cis.vu.nl/Projects.

- 2002b. In Search of Promising Practices in Science, Mathematics, and ICT Education in Sub-Saharan Africa. Master thesis. Enschede: University of Twente. 
. 2002c. "The Mathematics and Science Teachers' Extension programme in Namibia." In K. O-saki, K. Hosea, and W. Ottevanger, eds., Reforming science and mathematics education in Sub-Saharan Africa. Dar es Salaam: TEAMS project.

- 2007. Improved learning in Sub-Saharan classrooms. The complexity of curriculum reform. Draft doctoral dissertation. Enschede: University of Twente.

Mafumiko, F. 2006. Micro-scale experimentation as a catalyst for improving the chemistry curriculum in Tanzania. Doctoral thesis. Enschede: University of Twente.

Marsh, C., and G. Willis. 1999. Curriculum: Alternative Approaches, Ongoing Issues. New Jersey: Merrill.

Mingat, Alain. 2004. "Issues of financial sustainability in the development of Secondary Education in Africa." Paper presented at the SEIA donor conference Amsterdam, October.

Muller, Johan. 2004. "Assessment, qualifications and the National Qualifications Framework in South African Schooling.” In L. Chisholm, eds., Changing Class. Cape Town: HSRC Press.

O-saki, K. 2001. "Reflections on the state of science education in Tanzania.” In K. O-saki, K. Hosea, and W. Ottevanger, eds. Reforming science and mathematics education in Sub-Saharan Africa. Dar es Salaam: TEAMS project.

O-saki, K., and A. Ndabili. 2003. Secondary Education Sector Analysis. Dar es Salaam; Ministry of Education and Culture and the World Bank.

O'Sullivan, M. 2004. “The reconceptualisation of learner-centered approaches: a Namibian case study." International Journal of Educational Development 24:585-602.

Ottevanger, W. 2001. Teacher support materials as catalyst for science curriculum implementation in Namibia. Doctoral thesis. Enschede: University of Twente.

Ottevanger, W., J. van den Akker, and L. de Feiter. 2004. Developing science, mathematics and ICT education in Sub-Saharan Africa. Washington, D.C.: The World Bank.

Prophet, R. 1995. "Views from the Botswana Junior Secondary Classroom: Case study of a curriculum intervention." International Journal for Educational Development 15(2):127-40.

Republic of Botswana. 1994. The Revised National Policy on Education. Gaborone: Ministry of Education.

- 1997. Vision 2016. Towards Prosperity for All. A Summary. Gaborone: GRB.

- 2001. Report on the monitoring of learning achievements. Gaborone: Examinations Research and Testing Division.

Republic of Ghana. 2002. Meeting the Challenges of Education in the Twenty First Century. Legon-Accra: Adwinsa Publications.

Rogan, J. 2000. "Strawberries, cream and the implementation of curriculum 2005: Towards a research agenda." South African Journal of Education 20(2):118-25.

- 2001. "Towards a theory of curriculum implementation with particular reference to science education in developing countries." International Journal of Science Education 25(10):1171-1204.

Rowell, P., and R. Prophet. 1990. "Curriculum in action: The 'practical' dimension in Botswana classrooms.” International Journal of Educational Development 10(1):17-26.

Ruiz-Primo, M. 2005. "A multi-method and multi-source approach for studying fidelity of implementation." Paper presented at the AERA annual meeting, Montreal, Canada, April.

Samoff, J. 2005. "Education quality: difficult choices." Paper prepared at the expert meeting on researching quality of Education for All in the South: main issues and current gaps. University of Amsterdam, August 29-30. 
Scriven, M. 1999. "Inaugural Lecture.” University of Auckland, New Zealand, August. Accessed August 2005 at www.auklanduniversity.com.

Sharp, C. 2002. A Study into Homework. Berkshire: National Foundation for Educational Research.

Towse, P., J. Anamuah-Mensha, P. Mushi, and D. Kent. 2005. Bridging the gap: linking school and the world of work. Winneba: SACOST.

Transparency International. 2005. Corruption Perception Index 2005. November 2005 at www.transparency-international.org.

Umalusi. 2004. Investigation into the Senior Certificate Examination. Pretoria.

UNESCO. 2004. “Jomtien 1990-Dakar 2000. Lessons learnt.” Accessed February 2004 at www.unesco.org.

- 2005. Education for all: the quality imperative. Paris.

. 2006. Global Education Digest. Paris.

World Bank. 2002. World Bank support for provision of textbooks in Sub-Saharan Africa 1985-2000. Human Development Sector, Africa Region. Washington, D.C.

- 2003. "Proceedings from the first regional conference on secondary education in Africa (SEIA), Kampala, Uganda, June 2003.” Washington, D.C.

Young, M. 2004. "National qualification frameworks: their feasibility and effective implementation in developing countries." Geneva: ILO. 


\section{Eco-Audit}

\section{Environmental Benefits Statement}

The World Bank is committed to preserving Endangered Forests and natural resources. We print World Bank Working Papers and Country Studies on 100 percent postconsumer recycled paper, processed chlorine free. The World Bank has formally agreed to follow the recommended standards for paper usage set by Green Press Initiative-a nonprofit program supporting publishers in using fiber that is not sourced from Endangered Forests. For more information, visit www.greenpressinitiative.org.

In 2007, the printing of these books on recycled paper saved the following:

\begin{tabular}{|c|c|c|c|c|}
\hline Trees* ${ }^{\star}$ & Solid Waste & Water & Net Greenhouse Gases & Total Energy \\
\hline 264 & 12,419 & 96,126 & 23,289 & 184 mil. \\
\hline $\begin{array}{l}y^{40}-\text { in height and } \\
6-8 \text { in iameter }\end{array}$ & Pounds & Gallons & Pounds $\mathrm{CO}_{2}$ Equivalent & BTUs \\
\hline
\end{tabular}


Curricula, Examinations, and Assessment in Secondary Education in Sub-Saharan Africa is part of the World Bank Working Paper series. These papers are published to communicate the results of the Bank's ongoing research and to stimulate public discussion.

Economic and social changes, fast evolution of technology, and the growing importance of internet services and international communications - all these require secondary education providers to adapt what is taught and learned in schools. However, in Africa the content of secondary curricula is in most cases ill-adapted to $21^{\text {st }}$ century challenges, where young people are mobile, have access to "more and instant information," and face health threats such as HIV/AIDS. In addition, implementation problems exist, and the time for instruction is often much less than what is required by the prescribed secondary curriculum. In Africa there is a need to develop a secondary education curriculum adapted to the local economic and social environment, but with internationally-comparable performance indicators. This study analyzes that challenge: the quality of curricula and assessment, and their development processes in secondary education in Africa against the background of existing contexts, conditions, and ambitions on the one hand and current pedagogical thinking on the other.

This study was prepared as part of the Secondary Education and Training in Africa (SEIA) initiative which aims to assist countries to develop sustainable strategies for expansion and quality improvements in secondary education and training. AII SEIA products are available on its website: www.worldbank.org/afr/seia.

World Bank Working Papers are available individually or on standing order. Also available online through the World Bank e-Library (www.worldbank.org/elibrary).

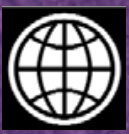

ISBN 978-0-8213-7348-4

THE WORLD BANK

1818 H Street, NW

Washington, DC 20433 USA

Telephone: 202 473-1000

Internet: www.worldbank.org

E-mail: feedback@worldbank.org

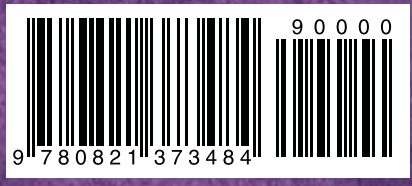

SKU 17348 